UNIVERSIDADE DE SÃO PAULO

FACULDADE DE FILOSOFIA, LETRAS E CIÊNCIAS HUMANAS

DEPARTAMETNO DE LINGUISITICA

\title{
SEQÜÊNCIAS EXPLICATIVAS PRODUZIDAS PELA CRIANÇA DE CINCO ANOS DE IDADE EM ATIVIDADE LÚDICA.
}

\author{
Ana Lúcia da Silveira Barros
}

Dissertação apresentada ao Programa de Pós- Graduação do Departamento de Lingüística da Faculdade de Filosofia, Letras e Ciências Humanas, para obtenção do título de Mestre.

Área de concentração: Semiótica e Lingüística Geral.

Orientadora: Prof ${ }^{\mathrm{a}}$. Dr ${ }^{\mathrm{a}}$. Lélia Erbolato Melo

São Paulo

2005 
"O imaginário é o motor do real,

o que o movimenta"

JAQUELINE HELD 


\section{AGRADECIMENTOS}

Agradeço imensamente aos que vivenciaram comigo este período de estudo:

À Prof ${ }^{\mathrm{a}}$ Dr $^{\mathrm{a}}$ Lélia Erbolato Melo pela disponibilidade e atenção sempre oferecidas, pela direção apontando leituras importantes, pelas discussões teóricas e intervenções sempre bem apropriadas que muito contribuíram para meu crescimento acadêmico e profissional e, pelo grande incentivo e encorajamento.

Às Professoras Doutoras Jacy Perissinoto e Ana Luiza Navas, pelas sugestões e indicações que me ofereceram no momento do Exame de Qualificação.

Às queridas professoras e colegas integrantes do Grupo de Pesquisa em Psicolingüística (GPPL), Terezinha, Priscila e Liliane, Anna Paula, Maristela, Nádia, Ana Karina, Ana Lúcia Artoni, Ana Lúcia Cabral, Célia, e incluo novamente as professoras doutoras Jacy e Lélia, pelos seminários e discussões teóricas que contribuíram para meu amadurecimento acadêmico.

Aos professores doutores, Lineide, Claudemir e Ângela por compartilharem de suas experiências acadêmicas, conselhos, conversas e sugestões dadas durante o percurso de meus estudos.

Às crianças que graciosamente colaboraram com a pesquisa, fornecendo os preciosos dados para a análise.

Aos professores e aos secretários e funcionários do Departamento de Lingüística da Faculdade de Filosofia, Letras e Ciências Humanas da Universidade de São Paulo, pelo papel desempenhado no desenvolvimento de minha formação acadêmica.

À minha querida família, meus pais e irmãos e a todos meus amigos, principalmente Isabel, Sayuri, Corina e outros por compreenderem os momentos de ausências e colaborarem nos momentos solicitados. 
A minha amiga Cristina que contribuiu com seus conhecimentos, fornecendo valorosa colaboração.

Ao meu amado esposo Luiz Henrique pela compreensão, carinho, incentivo e ajuda ao longo deste percurso. 


\section{RESUMO}

Nesta pesquisa, examinamos a ação comunicativa e a linguagem presentes no jogo de ficção, enfatizando as seqüências de explicação e justificação produzidas pela criança. Concebendo a explicação, como conduta que se desenvolve num contexto interativo e, as condutas explicativas e justificativas (CEJ) como manifestações do uso informativo da linguagem ligado à capacidade de considerar os estados mentais do outro (Veneziano e Hudelot, 2003), analisamos a interação entre adulto e criança de cinco anos de idade, enfatizando as explicações/justificações produzidas em atividade lúdica de ficção.

Vários estudiosos (François,1996; Hudelot,1997; Hudelot e Vasseur,1997) mostram que condutas discursivas do adulto trazem efeitos para a interação, pois são intervenções que suscitam reações na criança. Apoiadas na organização e elaboração do jogo de ficção proposto por Verba (1999), utilizamos o jogo "Lego" para intermediar a interação entre adulto - criança e relacionarmos as condutas discursivas do adulto ás condutas explicativas/ justificativas na criança. Como salienta a autora (op. cit), o jogo de ficção partilhado necessita do estabelecimento de um conjunto de significações comuns, resultante da elaboração das trocas sociais entre os parceiros que permitam, a cada participante, interpretar os "dizeres" e "fazeres" do outro no contexto do jogo.

Sob a ótica de que a explicação aparece como forma de modificar as representações do outro, a intenção foi verificar como as condutas explicativas / justificativas colaboram para a elaboração e organização do jogo de ficção. Assim, correlacionamos posições discursivas do adulto, sugeridas por Hudelot (1987), às formas tutelares, propostas por Verba (1990) para o jogo de ficção, na produção de condutas explicativas/ justificativas pela criança.

Constatamos, nas atividades lúdicas observadas, que o adulto geralmente solicita explicações, pois muitas das significações dadas pela criança, ou não foram compreendidas, ou houve um distanciamento entre as significações de ambos, de maneira a criar um desentendimento. Também observamos momentos em que a criança antecipa suas explicações e justificações para negociar seu ponto de vista e, conduzir o adulto em sua proposição. Desta forma, confirmamos nossa hipótese de que as condutas explicativas/ justificativas, na atividade de faz-de-conta, aparecem na situação de interlocução, tanto quando a interação e/ ou a comunicação se interrompe por falta de compreensão a uma dada questão, geralmente presente na partilha de significações, quanto quando há um 
distanciamento entre intenções, idéias e significações, promovendo a negociação de sentidos.

As condutas explicativas/ justificativas no jogo de ficção com o "Lego" manifestaram-se, nas várias ocasiões em que a imaginação da criança prevalecia. Às vezes, o adulto solicitava uma explicação para entender melhor a fantasia da criança e poder participar da atividade junto a ela. Enfim, fica comprovado que, o jogo de ficção partilhado possibilita à criança desenvolver habilidades para representar o mundo e, ao estabelecer relações entre as coisas e confrontá-las com o outro, favorecer o desenvolvimento de competências para argumentar, explicar e justificar.

Palavras-chave: explicação,jogo de ficção, linguagem, faz-de-conta, criança. 


\begin{abstract}
In this research, we examine the communication and the language in the fiction game, emphasizing the sequences about explanation and justification produced by the child. Conceiving the explanation as a conduct that is developed in an interactive context and that the explanation and justification conducts (CEJ) are language informative use manifestations, linked to the capacity of considering the mental state of the other one (Veneziano and Hudelot, 2003), we analyze the interaction between an adult and a five year old child, focusing the explications and justifications in a playful activity of fiction.

Several studies (François, 1996; Hudelot, 1997; Hudelot and Vasseur, 1997) show that adult's discursive conducts bring effects for the interaction, because they are interventions that raise reactions in the child. Supported in the organization and elaboration of the fiction game proposed for Verba (1999) use the game "Lego" to intermediate the interaction between adult-child and relate adult's discursive conducts with explanation/justification's conducts in the child. As the author points out (op. cit), the partitioned fiction game needs the establishment of a common significances, resultanting the elaboration of the social changes between partners, who allow, the each participant, interpret from other's talking and doing in the context of the game.

Under the optics that the explanation appears as a way to modifying the other's representations, the intention was to verify how the explanations /justification's conducts collaborate for the elaboration and organization of the fiction game. So, we examine how the adult's discursive relations suggested by Hudelot (1987) behaved, in relation to the proposed tutelary categories for Verba (1990) for the fiction game, in the explanation /justification's conducts produced by the child.

We verify, in the observed fiction activities, that the adult generally asks explanations, because many of the significances given by the child were not understood or there was a distance among significances between each other in order to create a misunderstanding. We also observed the moments in which the child foresees his/her explanations and justifications to negotiate his/her point of view and, lead the adult in his/her proposition. Thus, we confirmed our hypothesis that the explanation/ justification's conducts, in the fiction activity, appear on the dialogue situation, as much when the interaction or the communication is interrupted for the lack of comprehension of one
\end{abstract}


matter, arisen in this playful activity, as much when there is a distance between his/her intentions, ideas and significances.

The explanation/justification's conducts in the fiction game with "Lego" were present in many occasions in the objects significances division, actions events and linkages, in which child's imagination prevailed. Sometimes, the adult asked an explanation to understand the child's fantasy better and take part in the activity close to him/her. Finally, it is proved that partitioned fiction game enables to the child develop abilities to represent the world and, when establishing relations among things and confronts them with other person, it makes use of the development to of competences to argue, to explain and to justify.

Key-words: Explanation, fiction game, language, child. 


\section{SUMÁRIO}

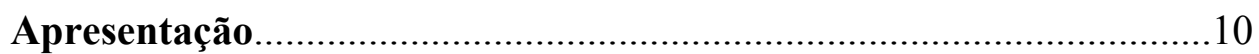

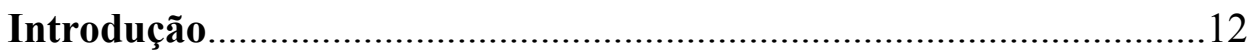

Capítulo I: Jogo de faz-de-conta, brincadeira e brinquedo

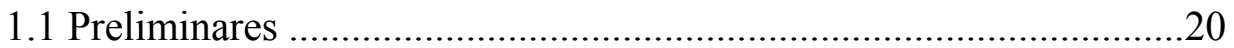

1.2 Uma visão do jogo em um contexto da construção e partilha

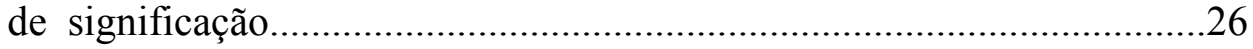

$1.3 \mathrm{O}$ brincar e o imaginário no universo da ficção................................30

1.4 Sobre a representação e o faz-de-conta.............................................33

Capítulo II: Linguagem e pensamento/cognição: algumas reflexões

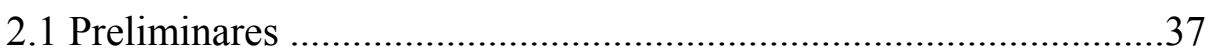

$2.2 \mathrm{O}$ discurso explicativo: em torno da argumentação .......................42

2.3 A explicação na criança a partir de diferentes olhares ...................47

2.4 As condutas explicativas /justificativas no jogo de faz-de-conta

\section{Capítulo III: Efeitos da tutela na conduta explicativa/justificativa} na atividade de faz-de-conta

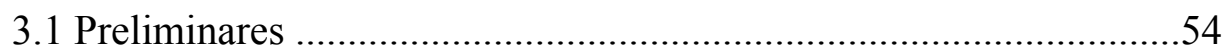

3.2 Conceitos e tipos de tutela: a tutela discursiva ..............................57

3.3 As dinâmicas sociais e cognitivas e a posição discursiva do adulto na ficção

\section{Capítulo IV: Material e Método}

4.1 Escolha dos sujeitos e do material................................................66

4.2 Procedimentos adotados na coleta de dados..................................67

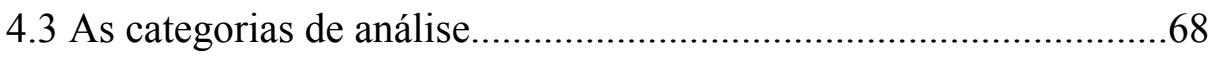

Capítulo V: Análise e interpretação dos resultados..............................71

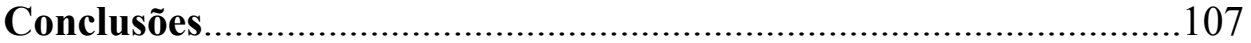

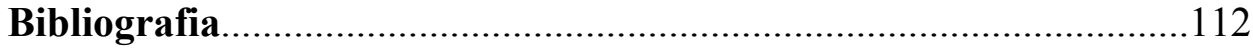

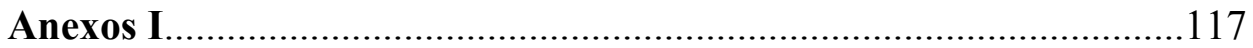

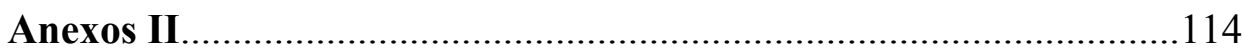

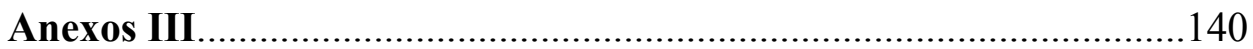




\section{JUSTIFICATIVA}

A relação entre adulto e criança, na fase do desenvolvimento, vem sendo examinada, ao longo do tempo, por muitos estudiosos do assunto em diferentes abordagens e perspectivas. Foi dentro deste contexto que buscamos nosso objeto de estudo. Ele surge, principalmente, como uma conseqüência natural de nossa atuação como fonoaudióloga, como profissional que está acostumada a lidar com as habilidades pressupostas na aquisição e desenvolvimento da linguagem. Freqüentemente, recorremos, em nossa prática, ás atividades lúdicas para interagir com as crianças, a fim de desenvolver suas habilidades lingüísticas, discursivas, pragmáticas, comunicacionais (entre outras).

Tendo formação em psicodrama aplicado á educação e outras áreas afins, sempre nos interessamos também pelo jogo corporal, e atuamos também junto á um grupo de profissionais de diferentes áreas, dentro de um projeto que visava á educação de crianças nas questões de saúde e na qualidade de vida.

Com base, portanto, nestas experiências anteriores e, sobretudo, a partir das leituras sugeridas pela Prof ${ }^{a}$. Dr ${ }^{\mathrm{a}}$. Lélia Erbolato Melo, bem como pela participação, com apresentação de trabalho, em eventos científicos na área de lingüística, optamos por estudar o discurso explicativo, sua função e efeitos na brincadeira de ficção (no caso, com o brinquedo "lego"), com a intenção de identificar as seqüências explicativas produzidas pela criança pequena, em situações interativas com o adulto.

Hudelot et all (2003) avalia as condutas explicativas/ justificativas como condutas que, pelo aspecto reflexivo, mobiliza a criança nas suas relações com os objetos, com a interlocução e com a linguagem. Da prática como fonoaudióloga, que atua com atividades lúdicas como meio para desenvolver a linguagem, da observação de crianças em situação lúdica e das leituras sugeridas pela $\operatorname{Prof}^{\mathrm{a}} \mathrm{Dr}^{\mathrm{a}}$ Lélia Erbolato Melo, passamos a formular algumas questões: a) como as condutas explicativas se manifestam na atividade ficcional e qual seu papel para o desenvolvimento infantil? ; b) que relações podemos identificar entre as condutas explicativas e as condutas do adulto, no momento de sua interação discursiva, por ocasião da realização de uma atividade ficcional em que o imaginário se faz presente?

A escolha pelo jogo "Lego" se deu devido ao fato deste ter estado presente em nossa vida de diversas formas. Desde quando era criança e brincávamos por prazer, até hoje, quando brincamos com as crianças porque participamos da brincadeira delas. Além disto, sabemos que é um jogo muito utilizado pela maioria das escolas de educação infantil, 
portanto também presente na vida de muitas crianças. Este jogo possibilita construir objetos, personagens e elaborar seqüências de eventos com imaginação e criatividade. A criança constrói objetos, personagens, cenários e os envolve numa seqüência de eventos e ações fictícias, criando situações e diálogos de faz-de-conta. Assim, consideramos o jogo "Lego" para criarmos a situação de faz-de-conta e estudar sua comunicação peculiar, seguindo em direção às condutas explicativas/ justificativas. 
O ser humano reflete as características de sua espécie adquiridas filogeneticamente na sua evolução ontogenética. Sua atividade e psiquismo compreendem a relação entre essas particularidades e as adquiridas durante o desenvolvimento humano, transmitido de geração a geração, reorganizadas e reproduzidas por cada indivíduo e fixadas na cultura de cada grupo social. A comunicação e a linguagem atuam como forma de transmitir os conhecimentos e também de estruturar, organizar, conduzir e deflagrar este processo.

Desde o nascimento, o recém-nascido é envolvido no ambiente pela ação comunicativa inerente a toda e qualquer interação social. Neste processo, a experiência do bebê no contato com o adulto fornecerá a base para a sua experiência lingüística. Vale ressaltar que, a experiência comunicativa pode ser observada desde o nascimento, enquanto que a linguagem, só quando a criança passa a utilizar a fala.

Ao fazer uso da linguagem para se comunicar, a criança constrói uma diversidade de modos de significar. Sua fala apresenta características próprias e singulares, em razão das combinações que realiza com o que absorveu do outro e do que seu "self" elaborou, a partir da e na comunicação. A utilização da linguagem nos diferentes contextos de interação social, empregada com diferentes fins, promove o desenvolvimento de condutas e habilidades lingüísticas e cognitivas diferentes.

Nesta direção, a proposta desta pesquisa é estudar as condutas de explicação e justificação presentes em uma atividade de ficção com o jogo "Lego". Esse jogo favorece a construção de objetos, personagens, cenários, e possibilita a dramatização, isto é, o desencadeamento de eventos entre os elementos construídos. É neste contexto lúdico que estudamos as condutas explicativas/justificativas produzidas pela criança na interação com o adulto.

Segundo Verba (1999), a comunicação verbal é considerada fundamental na organização e elaboração dos jogos de ficção. A partir de alguns trabalhos recentes (Garvey, 1982; Fein, 1981; Giffin, 1984 apud Verba, 1999) foi estabelecida uma distinção entre os enunciados que surgem durante a atividade de ficção e que estão presentes nas situações em que os parceiros representam papéis, ou seja, na atuação dos parceiros no jogo, denominados de in frames ou acting (como os enunciados que aparecem na 
comunicação entre doente e médico, por exemplo); e os enunciados relacionados ao conteúdo e partilha propriamente dito. Este último tipo é denominado de "metacomunicação" na literatura inglesa. Verba (1990) e estudiosos franceses denominam de "metalúdica", ou de comunicação "com propósito de jogo". Este discurso envolve os processos de compreensão, entendimento e negociação que possibilitam a existência e manutenção da interação lúdica. Este tipo de enunciado apresenta várias funções na comunicação como partilhar experiências individuais, negociar os temas e os papéis, escolher os cenários e acessórios, avaliar as performances etc. Portanto, em seus estudos, Verba (1990) analisa o aspecto comunicativo dos jogos de ficção, destaca os processos de intercompreensão e negociação de sentidos na comunicação entre pares e seu papel no desenvolvimento cognitivo e social.

Para nós, a intenção desta comunicação "com propósito de jogo" é fazer o outro compreender para integrá-lo na brincadeira e, dessa forma, os interlocutores explicam, justificam, explicitam, negociam seus pontos de vista. Assim, o enfoque de nossa pesquisa é dado ao aspecto discursivo, destacando as condutas explicativas/justificativas produzidas na interação lúdica com o jogo de ficção, entre adulto e criança.

Segundo Vygotsky (1989) é a partir da interação com o outro que ocorre o aprendizado. O autor, enfatizando as relações sociais, aponta a importância do papel do adulto como mediador entre o meio social e cultural na aquisição e no desenvolvimento do conhecimento, atribuindo ao jogo um papel mais privilegiado que a mera instrução.

Partindo desta perspectiva, Bruner (1991), entre outros, buscaram mostrar como certas formas de interação social podem se internalizar, influenciando a formação dos processos individuais e a aprendizagem da criança em atividade com o adulto ou par mais competente. (Wertsch,1985; Bruner,1990; Rogoff,1990; Damon,1990,1998; apud Verba 1999). Paralelamente, vários estudiosos interpretam a pesquisa sociogenética não somente como transmissão e apropriação cultural, mas também como construção do conhecimento em um contexto de interação com o outro, (Elbers, Maier, Hoekstra e Hoogesteder,1992; Van der Veer e Valsiner, 1991; apud Verba,1999). Alguns estudos enfatizam a interação entre adulto-criança e chamam de tutela as interações que propiciam um desenvolvimento cognitivo (Wood, Bruner e Ross, 1976, 1983; apud Hudelot 1996).

Bruner (1991) delimita a tutela pelas condutas do adulto ou par competente que auxiliam a criança a desenvolver competências que facilitem a resolução de problemas. 
Hudelot $(1996,1997)$ e François (1996) mostram que as condutas discursivas do adulto são intervenções que, na e pela comunicação entre os sujeitos, provocam efeitos na interação. François (1996) insiste no modo com que a criança reage ao discurso e ás diferentes formas de intervenções discursivas realizadas pelo adulto. Hudelot $(1996,1997)$ considera a tutela um fenômeno discursivo que apresenta características dependentes da interação e das condições da tarefa. Assim, a tutela enquanto apoio que o adulto fornece à criança ao realizar uma tarefa que, sem ajuda ela não poderia realizar sozinha, toma sentido diferente quando a atividade é linguageira e não somente a resolução de um problema.

Então, como situar a tutela, em se tratando de jogo de ficção, que envolve a atividade linguageira e, a construção e a montagem com o "Lego", ou seja, uma atividade prática, linguageira e permeada pela situação imaginária? Se a concepção de tutela delimita dois pólos na interação, um como sendo o de quem sabe (o expert) e o outro como o de quem não sabe (o aprendiz), o quadro teórico se difere ao da concepção que considera a tutela como a ação do adulto de introduzir a criança na interação, partindo de um mesmo plano cognitivo, afetivo e relacional, com intuito de conduzi-la a um pensar, fazer e dizer diferentes, (François, 1996; Hudelot,1997; Melo 1998).

De acordo com esta concepção, adulto e criança estabelecem um quadro comum de referência a serem partilhadas por ambas as partes. Acreditamos que o adulto, nesta relação, não é alguém que sabe mais, mas alguém que já se apropriou do conhecimento sociocultural e, portanto, tem uma experiência anterior acumulada ao longo do tempo. Desta forma, a tutela, no jogo de ficção, refere-se à condução do adulto com intuito de favorecer a criança outras possibilidades de fazer-dizer, respeitando tanto as relações imaginárias que o jogo permite criar quanto às formas socioculturais permitidas pela cultura em que adulto-criança estão inseridos.Sob este ponto de vista, podemos dizer que a tutela se refere ás produções discursivas do adulto que tem um movimento reforçador, condutor, instigador.

Como enfatizam Hudelot, Préneron e Salazar - Orvig (2003), as condutas explicativas se revelam na relação de um enunciado e seu contexto, em encadeamentos discursivos que estabelecem uma relação de significação, manifestada pela co-articulação de dois enunciados, pelo menos, que mostram uma relação de conteúdo (especificação, explicação, explicitação, justificação e refutação) e uma relação com o outro. 
Veneziano (2003) ainda esclarece a distinção entre a explicação causal, que estabelece a ligação de causa entre dois eventos, e dos atos de explicação que implicam na identificação, pela criança, dos eventos ou ações que pedem para ser explicados.

Assim, o caráter explicativo do discurso não se verifica somente pelo uso do conectivo "por que", em questões e respostas, mas pelo uso de outros conectores, (senão, então,...) que levam à explicação formal, e também pela modificação do estado de conhecimentos de si e dos outros (Grize, 1981), ou de momentos em que a criança tem que resolver uma situação problemática ou difícil (Hudelot, Préneron e Salazar-Orvig, 2003). Assim, podemos pensar que a conduta explicativa pode aparecer:

a) na situação de tutela, quando o adulto busca modificar o estado de conhecimentos da criança, no contexto de interação;

b) na situação de tutela, quando o adulto conduz a criança na resolução de uma situação difícil ou problemática.

Vygotsky (1991) atribui ao jogo um papel privilegiado, em relação à instrução do adulto, ao enfatizar seu aspecto funcional no desenvolvimento.

Para Verba (1990), os jogos de ficção favorecem um tipo de comunicação entre os parceiros do jogo, que permite construir saberes partilhado. Como assinala a autora, os jogos de ficção são atividades cooperativas e, portanto, necessitam da partilha de significações, para possibilitar a coordenação intra e inter individual das ações e o encadeamento das idéias, que permitem o desenrolar do jogo. A tutela, sob o ponto de vista da autora (op. cit), está presente nos jogos de ficção como condutas do adulto que promovem a atividade simbólica da criança e que favoreçam as dinâmicas interativas que dão seqüência ao jogo.

Assim, o jogo de ficção se desenrola a partir das transformações simbólicas que os parceiros operam sobre os objetos e que são comunicadas através de ações e pela linguagem. A comunicação (verbal e não verbal), que se estabelece entre criança e adulto, privilegiam o entendimento, a compreensão e o partilhar de significação e negociação de sentidos, que são fatores imprescindíveis para que o jogo possa se realizar. A comunicação é que possibilita a formação de um quadro comum de referência entre os parceiros, sem o 
qual o jogo não se desenrola por não haver entendimento. Este quadro comum de referência deverá ser elaborado nas dinâmicas interativas entre adulto e criança.

Diante destas colocações, formulamos a hipótese em três crenças:

a) uma situação de comunicação necessita de quadros e contextos de significação que permitam a compreensão mútua;

b) uma situação de comunicação deve veicular representações e experiências dos parceiros do jogo para que sejam confrontadas e negociadas;

c) uma situação de comunicação pressupõe o estabelecimento de convenções comuns para que cada um possa interpretar os "dizeres" e "fazeres" do outro no contexto do jogo.

Pensamos que, somente neste contexto, o caráter explicativo do discurso encontra espaço para seu estudo. Do ponto de vista da análise do discurso, o jogo envolve a interação de pelo menos duas pessoas, portanto, de um receptor e um emissor, que obedecem às restrições gramaticais, conversacionais e textuais, e que dominem um conjunto complexo de saberes para que as significações sejam partilhadas. Porém, no jogo de ficção, como observamos acima, a partilha de significação e a negociação de sentidos entre os parceiros importa muito para o encadeamento com sucesso do jogo, principalmente com relação ao caráter ficcional, pois o imaginário do jogo, ou seja, as ações, eventos e objetos que são criados pela imaginação, têm que ser comunicado para que o jogo se desenvolva.

Desta forma, importa também para nossa pesquisa, o uso que os parceiros do jogo fazem da linguagem e as articulações discursivas realizadas nos diálogos. Assim, deve ser considerado: a) o aspecto pragmático, que estuda a linguagem enquanto ação, atividade humana exercida pelos interlocutores de interpretarem suas proposições, ou seja, a função interlocutiva da linguagem; b) o aspecto argumentativo, que estuda as articulações discursivas enquanto forma de negociação das distâncias entre os interlocutores, surgida numa questão que se processa na linguagem.

Veneziano (1990, trad. 2003) enfatiza que, no jogo de ficção, a criança a partir dos 20 meses de idade, já dá explicações das ações ou acontecimentos que foram criados pela 
sua imaginação. A criança, como analisa a autora, explica para informar ao seu interlocutor, partilhando a significação de sua ficção.

Veneziano e Hudelot (2002), em seus estudos sobre o desenvolvimento dos diferentes usos de utilização da linguagem, propõem que um dos usos informativos consiste em produzir para o interlocutor, explicações/ justificações. Essas condutas revelam que, quando se explica e/ou se justifica, de um lado se compartilha com o interlocutor relações que se estabelecem mentalmente entre acontecimentos, revelando-se estados internos, intencionais e cognitivos, indicando seu aspecto pragmático; e de outro, essas condutas comunicativas dirigidas ao interlocutor aparecem com intuito de intervir em suas crenças e comportamento assinalando, portanto, seu aspecto argumentativo.

Diversos autores sugerem que explicar é fazer o outro compreender (Borel, 1981; Coltier, 1989; Halté, 1988). Halté (1988) enfatiza que o discurso explicativo surge quando há uma tensão entre os interlocutores provocando interrupção da interação ou da comunicação. Com a explicação, os interlocutores recuperam a interação ou a comunicação. Hudelot (2003) lembra que a explicação pode se manifestar como àquilo que vem preencher a distância entre as proposições dos interlocutores. Trata-se de um momento em que há um distanciamento entre o discurso de um e o discurso do outro, não necessariamente uma ruptura.

Desta forma, podemos inferir que a explicação aparece na situação de interlocução entre os parceiros do jogo em momentos específicos hipotéticos:

a) nas situações em que a interação e/ ou comunicação se interrompe por falta de compreensão em relação a uma dada questão, surgida durante o desenrolar da atividade lúdica;

b) nas situações em que aparece um distanciamento entre as intenções, idéias e significações apresentadas nas proposições de cada parceiro na atividade lúdica.

Como propõe Borel (1981:23), o "discurso explicativo não tem realidade semiótica quando isolado de seu contexto, das relações com outros discursos, da situação que o determina e em que tem seus efeitos".

Coltier (1989) enfatiza que o discurso explicativo depende da competência comunicativa da criança. A criança parte de seus saberes para justificar-se, para explicar ou 
mostrar seu saber e, para dar conta disto, deverá desenvolver certas habilidades. Habilidade de ver as coisas sob o ponto de vista do outro, ou seja, de descentração, que seria um sinal de cooperação intelectual, habilidade de organizar informações recebidas, habilidade lingüística de organizar informações, que serão transmitidas de forma que o outro possa compreendê-las. Dessa forma, a explicação dada pela criança terá finalidades diferentes e características pertinentes às diferentes habilidades, de acordo com a idade e a interação estabelecida com o outro.

Diante das justificativas apresentadas levantamos as seguintes questões, a serem respondidas ao longo do trabalho:

a) Nos jogos de ficção, os adultos levam a criança a produzir explicações quando surgem obstáculos? Que relações se observam entre as condutas tutelares e as condutas explicativas?

b) Como as condutas explicativas / justificativas se apresentam no discurso da criança, durante o jogo de ficção?

c) As condutas discursivas que aparecem na atividade lúdica, no momento da partilha de significados e troca de informações favorecem o aparecimento de explicações?

Buscando responder a estas questões, examinamos as condutas explicativas/justificativas e as condutas tutelares presentes nas seqüências explicativas produzidas em situação lúdica, entre adulto e criança com o objetivo de analisar a atividade simbólica na/da criança e o papel do adulto na situação de faz-de-conta com o brinquedo "Lego", correlacionando aspectos comunicacionais, lingüísticos e cognitivos em fase de aquisição e/ou desenvolvimento. Portanto, nossa intenção foi: a) analisar a organização interindividual dos jogos de ficção entre adulto e criança e o papel das condutas de explicação/ justificação nesta organização; b) entender os processos de compreensão e negociação de sentidos, bem como a partilha de significados, manifestada nas seqüências explicativas da criança; c) verificar até que ponto as condutas do adulto influenciam o surgimento das condutas explicativas/justificativas na criança, durante a atividade lúdica. 
Assim, no capítulo um, abordamos diferentes pressupostos teóricos referidos na literatura específica sobre jogo, imaginação e faz-de-conta. Apresentamos a concepção de jogo partilhado e suas características sob o ponto de vista de Verba (1990).

Em seguida, a intenção foi fazer uma breve reflexão teórica sobre explicação e argumentação. A partir disso, apresentamos a noção de condutas explicativas / justificativas e salientamos algumas correlações com o faz-de-conta.

No terceiro capítulo, tratamos da tutela na perspectiva discursiva discutindo aspectos fundamentais e importantes para o entendimento da interação adulto - criança, espaço fértil para condutas explicativas / justificativas.

No capítulo seguinte, descrevemos os procedimentos adotados para a escolha dos sujeitos e da coleta de dados, bem como do material utilizado para a pesquisa, e apresentamos os fios condutores da análise.

No capítulo cinco, interpretamos e comentamos os resultados relativos ás condutas explicativas / justificativas e suas relações com as condutas tutelares durante o jogo de ficção entre adulto e criança.

No capítulo conclusões, retomamos as questões iniciais destacando alguns aspectos relevantes entre tutela discursiva e condutas explicativas / justificativas no jogo de ficção. 


\subsection{Preliminares}

Brincar e jogar são atividades praticadas tanto pela criança, quanto pelo adulto, porém de maneiras diferenciadas. Buscando conceituar o termo jogo, recorremos à literatura específica e encontramos uma diversidade de sinônimos com o qual o termo é empregado. Kishimoto (2003) propõe uma diferenciação que será adotada por esse estudo: brinquedo compreende o objeto, suporte de brincadeira; brincadeira, como a descrição de uma conduta estruturada com regras; e jogo infantil para designar tanto o objeto, como as regras do jogo da criança, (brinquedo e brincadeiras).

Verificamos, também, que o jogo infantil é abordado sob diferentes pontos de vista na literatura. Kishimoto (2003) sugere algumas concepções: o jogo como possibilidade de eliminar o excesso de energia represada na criança (Spencer); como preparação da criança para a vida futura (Gross); como representação de um instinto herdado do passado (Stanley-Hall); como elemento fundamental para o equilíbrio emocional da criança (Freud, Claparède, Erikson, Winnicott).

$\mathrm{Na}$ psicologia cognitiva, Wallon (1981) se reporta ao jogo como uma forma de infração do cotidiano e suas normas; Bruner (1978) considera que a brincadeira permite uma flexibilidade na conduta e conduz a um comportamento exploratório; Vygotsky (1988) entende a brincadeira como uma situação imaginária criada pelo contato da criança com a realidade social; e Piaget (1976) postula que a brincadeira surge da predominância do comportamento de assimilação sobre a acomodação (princípio básico de sua teoria a noção de equilibração como mecanismo adaptativo da espécie).

Piaget (1978:144) mostra que há três tipos de jogo: de exercício, simbólico e de regras.

- O jogo de exercício envolve a repetição de seqüências já estabelecidas de ações e manipulações, não com propósitos práticos ou instrumentais, mas pelo prazer que essas ações e manipulações produzem.

- O jogo simbólico surge durante o segundo ano de vida com o aparecimento da representação e da linguagem. Segundo Piaget (1978), o jogo simbólico dá origem às 
representações individuais e à esquematização representativa. Constitui a manifestação de uma função mais geral do desenvolvimento que é a função semiótica, identificada no comportamento da criança a partir da aplicação de esquemas a objetos inadequados e a evocação para o prazer. Portanto, desenvolve-se com a descoberta da significação e consiste em uma diferenciação dos significantes (signos e símbolos) e dos significados (conceitos dos objetos e acontecimentos esquematizados), de modo que os primeiros permitam a evocação da representação dos segundos. A linguagem é vista como uma forma particular da função simbólica, indispensável à elaboração do pensamento no sentido de realizar a condensação simbólica e a regularização social.

- O terceiro tipo de jogo, o jogo de regras, marca a transição da atividade individual para a socialização. Este jogo não ocorre antes de 4 a 7 anos e predomina no período de 7 a 11 anos de idade. Para Piaget, (op.cit) a regra pressupõe a interação de dois indivíduos e sua função é regular e integrar o grupo social. Distingue dois tipos de regras: as transmitidas socialmente e as que são construídas espontaneamente.

Segundo o autor, (op.cit), há uma evolução entre os tipos, ou seja, o jogo de exercício é substituído pelo pensamento ou pelo símbolo e este, substituído pela regra. $\mathrm{Na}$ verdade, não se trata de mera substituição, mas de tranformação e reintegração de uma atividade á outra, ou seja, do exercício para o simbolismo e deste para as regras, dado a diferenciação progressiva :

“o jogo infantil é simplesmente a expressão de uma das fases dessa diferenciação progressiva: é o produto da assimilação dissociando-se da acomodação antes de se reintegrar nas formas de equilíbrio permanente que dele farao seu complemento, ao nível do pensamento operatório ou racional.” (Piaget, 1975, 207)

Piaget ( 1978) aponta seis critérios para caracterizar o jogo:

a) O jogo encontra finalidade em si mesmo.

b) É uma atividade espontânea oposta à atividade de trabalho.

c) É uma atividade que dá prazer, sendo uma busca subordinada à assimilação do real do eu. O prazer lúdico seria a expressão afetiva dessa assimilação. 
d) É desprovido de uma estrutura organizada em contraposição ao "pensamento sério", que é regulado.

e) As condutas no jogo são livres de conflito (ignora os conflitos ou liberta o "eu" através de uma solução de compensação ou liquidação).

f) É também uma atividade que envolve uma supramotivação, ou seja, o jogo começaria com a intervenção de motivos não contidos na ação inicial.

Friedmann (1996) destaca que, para Piaget, o ato de brincar é um comportamento que distorce a realidade "objetiva", serve para expressar o pensamento, mas não participa como gerador na construção deste. Seu enfoque é o indivíduo, na forma como o sujeito ativo apreende e se apropria dos conhecimentos. Já Vygotsky (1991) e Bruner (1987), partindo das concepções interacionistas, apontam o jogo como mediador de aprendizagem, central no desenvolvimento de certas habilidades cognitivas. A autora conclui que, apesar de apresentarem perspectivas diferentes, essas teorias parecem caminhar paralelamente sendo que, principalmente em relação ao jogo, Piaget dedica mais atenção à sua função no desenvolvimento da criança, enquanto Vygotsky insiste na questão cultural e no contexto social e interacional como determinantes para a atividade lúdica.

Em Vygotsky (1989), entendemos que o jogo é o elemento que irá impulsionar o desenvolvimento dentro da Zona de Desenvolvimento Proximal (ZDP). O brinquedo, assim, não deve ser entendido como uma ação simbólica no sentido próprio do termo (como um sistema de símbolos que generalizam a realidade). Seu papel no desenvolvimento se fundamenta mais pela motivação que gera e pelas circunstâncias envolvidas, e não somente pelos processos cognitivos implicados. O autor aponta dois elementos importantes na brincadeira infantil: a situação imaginária e as regras.

A situação imaginária, que envolve qualquer forma de brinquedo, contém regras de comportamento que determinam as ações no jogo. A ação da criança na situação imaginária ensina-lhe a dirigir seu comportamento pelo significado da situação. O brinquedo leva a criança a operar com um significado imaginário numa situação real, vinculado ao prazer. A criança aprende a seguir regras e também a se subordinar á elas. O essencial, no brinquedo, é que uma regra se torne um desejo, que ao ser realizado permite que as categorias básicas da realidade sejam vivenciadas pela criança. 
Como assinala o autor (op. cit), operar com significado de coisas, leva ao pensamento abstrato; e operar com significado de ações leva ao desenvolvimento da vontade e à capacidade de fazer escolhas conscientes. A imaginação, a interpretação e a vontade são processos internos conduzidos pela ação externa.

Partindo desta visão, Leontiev (1987a, 1987b apud Friedmann 1996:37), entende que a atividade lúdica surge na criança em um momento de contradição entre o desenvolvimento da necessidade de agir sobre os objetos e coisas e o desenvolvimento das operações que permitem realizar essas ações. Assim, o objetivo do jogo se dá no próprio processo e não no seu resultado. É quando a criança está desenvolvendo seu mental que o jogo torna-se sua principal atividade.

O autor acredita que a estrutura da atividade lúdica é que provoca o surgimento da atividade imaginária e destaca dois aspectos. A ação surge, como um processo dirigido a um objetivo, ligado a um motivo que dá sentido à brincadeira. Assim, a ação é que conduz para a descoberta da realidade objetiva. O conteúdo da ação corresponde às suas condições de existência: o significado está associado a esse conteúdo (Friedmann,op. cit). Desta forma, afirma que a atividade lúdica determina tanto as relações das crianças em relação ao objeto, quanto às relações das pessoas entre si. No jogo, surge o processo de subordinação do comportamento a certas regras de ação, condição importante para o aparecimento da consciência do princípio da própria regra.

Friedmann (op. cit.) ainda destaca a idéia de avaliação atribuída por Leontiev: a criança começa a julgar por si mesma suas próprias ações, suas habilidades, possibilidades e progresso através da comparação com outras crianças.

Coscione (1988) define jogo como a capacidade de agir, por iniciativa própria, aos estímulos, objetos e fatos do meio exterior. Jogo é ação. O pensamento e a ação não são atividades separadas. O jogo dá às crianças uma razão intrínseca para o exercício de sua inteligência e da sua criatividade. A inteligência vai se desenvolvendo, na medida em que está sendo solicitada. Para a autora ( op. cit), os jogos contribuem para a formação de sentimentos e atitudes de cooperação e respeito mútuo. Como o jogo implica ação, faz-se necessária uma fase de adaptação e reconhecimento que permite a exploração de todas as suas possibilidades de forma livre, sem regras. Conforme o jogo vai se desenvolvendo, as regras podem ser sugeridas, ou pelo adulto, ou pela criança, ou pelo grupo.

A autora enumera alguns tipos de jogos e suas características: 
- jogos de sensibilização (ou de autoconhecimento) - propiciam aguçar os sentidos da criança e conhecer seus limites;

- jogo simbólico - meio pelo qual a criança expressa seu modo de ver as coisas e os conhecimentos de seu mundo real. No jogo simbólico, as crianças são ao mesmo tempo símbolos e criadoras de símbolos, exprimem simbolicamente uma grande parte de seu conhecimento social, recriam uma determinada situação, acentuando os aspectos que mais marcaram e que foram mais significativos para elas. Tanto o jogo simbólico como as histórias são instrumentos particularmente importantes no desenvolvimento da criança na medida em que favorecem a organização e reorganização de seus pensamentos, idéias, sentimentos e conhecimentos;

- jogos dramáticos - possibilitam a criança assimilar o real a seus próprios interesses, estabelecendo um jogo de faz-de-conta, ou seja, representar um personagem ou utilizar um objeto qualquer como símbolo para representar uma situação que ela deseja vivenciar. Esses jogos ajudam a desenvolver a linguagem e o vocabulário pela interação e pela necessidade de organização do pensamento. Desenvolve a capacidade de expressão ao possibilitar identificar-se com sentimentos de raiva, tristeza, aprender a expressá-los, dominá-los ou canalizá-los para outras atividades, adquirir informações sobre fatos, objetos ou sentimentos;

- jogos de construção: a criança representa seu conhecimento simbolicamente, brincando de faz-de-conta e criando situações e diálogos. Podem ser os blocos lógicos que se constituem de um conjunto de peças geométricas de cor, forma, espessura e tamanho variado que se combinam de diferentes modos, jogo livre, construções geométricas, construções de objetos ou figuras, etc., ou os jogos prontos de madeira ou plásticos, quebra cabeças etc., ou os jogos construídos pela própria criança com material tipo sucata.

Desta classificação podemos averiguar que em diferentes tipos de jogo o faz-deconta se faz presente. Desde o jogo simbólico, quando a recriam situações vividas a partir dos símbolos aos jogos dramáticos e os de construção.

Novamente temos esta sutil diferença com Wallon (s.d. apud Kishimoto 2003: 41), que considera a atividade lúdica como uma forma de exploração, de infração da situação presente. $\mathrm{O}$ autor classifica o jogo em quatro tipos: funcionais, de ficção, de aquisição e de 
construção. Os jogos do tipo funcional são os que representam a movimentação simples de braços, pernas, o balançar de objetos. Os de ficção são as brincadeiras de faz-de-conta. Os de aquisição são os que favorecem um aprendizado da criança, ou seja, em buscas para compreender as coisas e, os jogos de construção são os que proporcionam a combinação e a reunião de objetos entre si possibilitando a criação e modificação destes.

A partir destas clocações podemos considerar então, um grupo de jogos chamados de exercício, funcionais ou de sensibilização que envolvem o corpo da criança, o conhecimento de seus limites e sensações, e o segundo grupo que envolve o faz-de-conta, a representação e a imaginação.

Verba (1990) define o jogo de ficção como brincadeira que envolve o faz-de-conta, podendo ser realizado com objetos (brinquedos) ou não. É uma atividade em que a criança não se prende à realidade espaço-temporal e às convenções sociais. Quando o jogo de ficção é coletivo, o pensamento da criança é liberado da dificuldade do real, mas está condicionado à presença do parceiro para se ajustar. A autora (op. cit) vê o jogo de fícção partilhado como sendo uma atividade cooperativa que necessita de um quadro comum de referência resultante da construção e partilha de significações elaboradas nas trocas sociais.

Para Friedmann (1996) os jogos de faz-de-conta são atividades em que a criança representa papéis. Pode haver uso de objetos ou não, mas há sempre uma situação imaginária implicada na interação da criança com o meio ou com o parceiro.

É importante ressaltar que, na literatura, podemos empregar o termo jogo de ficção, jogo de faz-de-conta, ou somente faz-de-conta para a mesma noção. Com base na distinção de Kishimoto (2003), já citada anteriormente e Friedmann (1996) citada acima, utilizaremos o termo jogo e não brincadeira já que, na pesquisa, estaremos lidando com o jogo "Lego" que envolve tanto o brinquedo quanto as regras, e o termo ficção ou faz-deconta por estar envolvido em uma situação imaginária .

Com relação ao jogo "Lego", observamos que, num primeiro momento, as crianças constroem objetos e brincam de forma livre e exploratória. Aos poucos, é que as regras vão se estabelecendo, as idéias vão surgindo e o jogo se desenrola a partir das proposições dadas, tanto pelo adulto quanto pela criança. Assim, o jogo "Lego" é um jogo de construção, que também favorece a dramatização. Além de permitir à criança, representar simbolicamente seus conhecimentos, também possibilita a criação de situações e diálogos de faz-de-conta, assim como a representação de papéis. 


\subsection{Uma visão do jogo em um contexto da construção e partilha de}

significações.

Conforme mostra Verba (1990), na comunicação entre os indivíduos, as referências às significações são convencionais e socialmente codificadas, permitindo a compreensão mútua. Nos jogos de ficção, as referências a essas significações convencionais estão ausentes e, portanto, é necessário que se crie um quadro de significações comuns, que atue como referência. $\mathrm{O}$ conjunto destas significações comuns resulta da elaboração das trocas sociais. Durante a brincadeira, as significações individuais surgem das representações e das experiências vivenciadas por cada parceiro separadamente. Cada parceiro deverá assim, comunicar as significações pessoais que veiculam a experiências e as representações de cada um, que ao serem confrontadas, criam uma zona intermediária de "colocação comum" de pensamento.

Os jogos de ficção partilhados possibilitam a criança criar de acordo com sua fantasia, fazer ligações subjetivas, inverter a ordem das coisas e modificar regras, mas ela ainda permanece assujeitada á presença do outro, ao qual deve se ajustar. Desta forma, cada parceiro do jogo explora sua fantasia e imaginação, mas precisam comunicar seus pensamentos, idéias e intenções. A coordenação das atividades simbólicas só se torna possível se os parceiros partilharem o estatuto de ficção e as significações atribuídas aos eventos, personagens e objetos (Verba, 1990).

A autora (op.cit) distingue três tipos de situações para a atividade de ficção de acordo com o tipo de material utilizadao. Assim, temos: as brincadeiras livres sem objetos; as brincadeiras com objetos que evocam significações pelo seu uso em situações cotidianas; e, as com objetos familiares que não evocam significações particulares, como no caso dos blocos de montar. Neste caso, as referências aos significados, atribuídos a cada montagem, devem comunicadas. Há situações em que um objeto montado pode ter sua significação compreendida implicitamente, decorrente da manipulação do parceiro no conjunto do cenário.

Em Verba (1999) destacamos que diferentes formas de representação se desenvolvem das diferentes significações surgidas durante o jogo de ficção. Das atividades mentais envolvidas, que dão suporte às atividades lúdicas, a autora discrimina dois aspectos: as transformações simbólicas, e as idéias e evocação de eventos e estados. 
O primeiro aspecto se refere às atividades simbólicas. São as transformações simbólicas ou construções simbólicas que representam objetos, animais, lugares, (uma montagem com os blocos se transforma em carro, por exemplo). $\mathrm{O}$ segundo, se refere às atividades imaginárias, em que ocorre a evocação de eventos ou estados que se encadeiam num cenário e se desenrolam em uma seqüência de fatos, (um carrinho segue por uma estrada para chegar à praia, por exemplo).

A autora (1990) delimita os episódios de transformações simbólicas ou construções simbólicas em seqüências constituídas principalmente e exclusivamente pela denominação e caracterização dos significados atribuídos aos objetos, personagens e lugares que foram construídos com o "Lego". Há: a) os episódios de transformações simples, os quais não há cenários e nem papéis a serem representados, somente a atribuição de denominações e caracterizações aos objetos montados, personagens e ações. Exemplo: a criança monta com o "Lego", um carrinho, mostra e fala: é um carrinho; b) os episódios de transformações complexas, que são os episódios de transformações simbólicas associados à ação de faz-deconta como reforço á significação atribuída aos objetos montados. Ex. A criança monta um carrinho e brinca com ele empurrando e imitando a onomatopéia de sua buzina, freada, aceleração etc.

E também, há os episódios de "jogo de faz-de-conta propriamente ditos", que segundo Verba (1990), correspondem às transformações simbólicas e seqüência de eventos, ou seja, englobam as construções simbólicas (objetos, personagens, cenário montados) envolvidas em uma seqüência de eventos, com tema e papéis representados. Estes episódios são mais complexos, pois a criança estabelece relações lógico-temporais, cria eventos com causa-efeito e etc. São episódios que se desenrolam ao redor de um tema, diferente dos anteriores em que a criança simplesmente monta e desmonta objetos através do "Lego". Exemplo: criança monta a mesa, o fogão, a geladeira, o quarto e faz-de-conta que os bonecos montados acordam e vão tomar café.

Gardner (1994) nos esclarece melhor estas duas situações. Segundo o autor (op. cit:61), "nomear e classificar são aspectos centrais da linguagem". A nomeação leva a criança a diferenciar objetos, pela sua forma, função ou outra categorização. É uma capacidade ligada ao universo da significação. Entendemos que nos episódios de transformação simbólica ou construção simbólica prevalece esta capacidade. A criança realiza a montagem e nomeia sua construção com os blocos. 
Ainda o autor ( op. cit) refere sobre outro uso da linguagem que envolve a descrição de eventos recorrentes, que ele chama de "uso de roteiros" e que "revela a determinação pela criança de importantes seqüências de eventos familiares em seu ambiente" (Gardner,1994:62).Observamos que, os episódios de "faz-de-conta propriamente dito" trata da identificação e ordenamento das montagens com os blocos numa seqüência de eventos, baseada em roteiros. A criança desenvolve os temas, os personagens e ainda, criam cenários e encadeiam seqüências de eventos, a partir dos roteiros que conhece e que foram determinados pela sua experiência de vida.

Com relação à atividade de ficção partilhada, Verba (op. cit) verifica três aspectos distintos: 1) a imaginação do conteúdo; 2) a partilha com os parceiros; 3) a gestão do jogo.

1) A imaginação e a criação articulam diversas atividades mentais desde as construções ou transformações simbólicas realizadas com blocos e com os objetos montados até o surgimento e criação de idéias e eventos. As construções simbólicas ou transformações simbólicas envolvem os encaixes realizados com os blocos (uma montagem de peças representa um objeto, um objeto significa outro); com as personagens (a criança coloca-se no lugar de um personagem, um bloco torna-se um personagem); com os lugares (um encaixe é a casa, outro é o portão do sítio); e com o tempo (momento de passear, momento de comer). Nesta atividade cognitiva, as crianças atribuem significações pessoais aos elementos da situação. Quando surgem as "idéias" que compõe a história, as situações e os encadeamentos dos eventos, elas devem ser comunicadas por ações ou enunciados, ou então aparecerem nas transações, sob forma de proposições, para serem aceitas, negociadas ou rejeitadas pelo parceiro. O encadeamento das "idéias" constitui o desenvolvimento dos elementos do cenário ou do tema da história.

2) Com relação á partilha, Verba (1990) salienta que o caráter fictício precisa ser bem especificado. A partilha decorre do acordo entre proposições e intenções dos participantes do jogo, estabelecida pela necessidade de compreensão mútua. É quando se colocam acordos ou proposições entre o que foi montado com os blocos e a significação dada. A partilha necessita deste acordo que se constitui a partir do equilíbrio entre a afirmação de si e o reconhecimento do outro como parceiro. Pode ser obtido progressivamente através dos ajustes recíprocos ou de forma imediata, sem dificuldades. Pode ser mantido sem conflito (pelas demandas de confirmação, buscas de aprovação, 
aceitação e etc.), ou negociado em conseqüência de mal-entendidos ou discussões. O tema do jogo pode ser um facilitador para a constituição de um quadro de referência e ancoragem na partilha de significações.

3) A gestão do jogo decorre da imaginação e da partilha de significações, ou seja, a elaboração da forma do jogo se desdobra ao mesmo momento em que a do conteúdo do jogo. A gestão está relacionada com os eventos ou seqüência de eventos que se realizam a partir da montagem dos blocos. Como observa Verba (1990), freqüentemente os parceiros, não só criam e dirigem os elementos do jogo como também atuam representando papéis da história inventada. Eles supervisionam as performances de cada um, atraindo e mantendo a atenção do outro, propondo eventos, distribuindo papéis, escolhendo o cenário, de forma a conduzir a um bom desenrolar do jogo. A gestão pode aparecer em turnos alternadamente, ou como observamos em muitas ocasiões, iniciada pelo adulto e, posteriormente, pela criança.

A autora (op.cit) também evidencia a influência dos objetos e dos encadeamentos de eventos na interação no jogo, pois estes podem evocar, ou não, os mesmos significados para os parceiros. O conteúdo do jogo e as interações também podem variar dependendo do quadro referencial externo de cada parceiro (social, familiar, institucional), e pode aparecer subtendido ou não em suas atividades.

Vale ressaltar que, certas atividades sociais conduzem à elaboração e à organização dos jogos. Os elementos do cenário podem variar, mas as regras que subtendem sua organização são conhecidas e partilhadas pela criança. A atividade de cozinhar, por exemplo, é uma situação que orienta a elaboração da criança e organiza o jogo de determinada forma.

As crianças tendem a impor preferencialmente suas escolhas sobre o tema, sobre a caracterização de personagens e objetos, sobre a coordenação dos eventos e expressões de sentimentos. Quando não se tem um quadro de referência externo, freqüentemente, os parceiros, ou se apóiam nas experiências comuns e constroem as significações necessárias para um desenrolar coerente ou o adulto intervém, no sentido de auxiliar na significação. A referência aos significados pode vir implícita ou explicitamente. Quando os objetos não evocam nada em particular, é indispensável que, cada parceiro transmita ao outro, os significados que eles atribuíram. Mesmo assim, nas situações em que, o conjunto evoca cenas ou experiências socialmente codificadas, é necessário que a criança expresse seus 
pensamentos de forma clara e precisa, transmitindo os significados dados para que a elaboração do jogo tenha coerência. Caso contrário, o adulto, e até a própria criança, buscam compreender e se ajustar.

A comunicação estabelecida entre adulto e criança, com o objetivo de construir e partilhar significações pode ocorrer a qualquer momento do jogo. Pode ser verificada desde o início das montagens com os blocos, pode surgir durante os encadeamentos de eventos da história imaginada. Esta comunicação dirige-se aos elementos do jogo, informando algo a seu respeito, seja para situá-lo na atividade, seja para transmitir ao outro as intenções e ações a serem realizadas.

Geralmente, a criança realiza as construções simbólicas de maneira exploratória e livre, para depois desenrolar as seqüências de eventos. Muitas vezes, o adulto direciona a atividade, embora haja uma tendência da criança em impor suas idéias e temas. Tanto quando a criança está construindo suas montagens, quanto propondo suas idéias e desenvolvendo os eventos no jogo, a representação e a imaginação estão presentes. Imaginação e representação são aspectos fundamentais do faz-de-conta, e serão abordados a seguir.

\subsection{O brincar e o imaginário no universo da ficção}

Como Vygotsky (1991) postula, "a exploração dos saberes culturais é impossível sem a liberdade que possibilita a criança de explorar o mundo através do jogo e do imaginário". O autor entende que nos jogos, a criança constrói as representações do mundo ao mesmo tempo em que, estabelece relações entre os símbolos e seus referentes e os saberes relativos ao mundo social, suas ações e objetos. Através do brinquedo, a criança realiza seus desejos depositando sua atividade num mundo imaginário e ilusório.

Segundo Postic (1993), imaginar é evocar seres, situá-los em determinado contexto e fazê-lo viver conforme nossos desejos. Para o autor, imaginar é uma atividade paralela à ação que exercemos, ligada a realidade. A imaginação é o processo e o imaginário o seu produto.

Imaginar é uma atividade de transformação do real, seja de reconstrução em função dos significados dados, seja das repercussões interiores que vivenciamos. $\mathrm{O}$ desencadeamento da atividade imaginária é provocado por encontros emocionais entre o "real" e mim. A criança se descobre ao mesmo tempo em que age num processo de 
descoberta que não é racional, é mais vivida do que percebida. Assim, o imaginário está povoado de representações simbólicas do real e encontra seu centro, não na busca de um significado no plano racional, mas no despertar de imagens que ressoam e incorporam um sentido.

Como sugere Postic (1993), pela atividade imaginária a criança se confronta com os outros e com o real. Toma consciência de suas possibilidades de ação e de seus limites. Pela ação, ela pode buscar formas de modelar o seu próprio real e dominar sua emoção.

Na perspectiva psicanalista, o imaginário implica-se com os acontecimentos que ocorrem na vida afetiva do sujeito e nos efeitos que estes acontecimentos provocam em seu inconsciente. Estes compensam os aspectos da realidade que o decepcionam e que não correspondem à sua expectativa, realizando atividades no qual o imaginário predomina com o objetivo de ter seu desejo satisfeito.

Segundo Winnicott (1975) existe uma área "intermediária de experimentação", para a qual contribuem tanto a realidade interna quanto a externa na vida do ser humano. É a área da ilusão, da imaginação, espaço do brincar, da criatividade e da arte.

Davis e Wallbridge (1982) comentam as qualidades primordiais do brincar, apontadas por Winnicott.

* O importante para as crianças pequenas não é o conteúdo do jogo, mas o estado de quase afastamento que se cria, similar a uma concentração.

* No brincar, a criança pode manipular os fenômenos externos de acordo com suas fantasias e investe em fenômenos externos escolhidos com significados e sentimentos oníricos.

* Há uma evolução direta dos fenômenos transicionais para o brincar, do brincar para o brincar compartilhado e daí para as experiências culturais.

* Brincar implica em ter confiança no ambiente, na capacidade de ficar só na presença de alguém.

* Implica em manipulação de objetos, o que envolve o corpo e, portanto pode estar associado a certos tipos de excitação somática.

* A criança precisa sentir satisfação no jogo.

* O brincar atinge seu ponto de saturação ou auge, por assim dizer, quando se refere à capacidade de conter a experiência.

* Apresenta um aspecto precário e excitante dada à inter-relação da mente da criança entre o subjetivo e o percebido objetivamente. 
Para Winnicott (1975), o brincar é considerado como qualquer atividade que envolve criatividade do indivíduo e seu sentimento de estar presente. É no brincar que a criança é capaz de ser criativa, de usar sua personalidade e descobrir assim o seu "eu". O espaço da brincadeira, ou seja, o espaço onde o brincar se desenrola é chamado de espaço potencial e é neste que ocorre a comunicação significativa. A comunicação advém da mutualidade na experiência, da superposição de espaços potenciais que as relações interpessoais podem tornar-se fáceis e férteis no sentido de enriquecimento. Disso, decorre a importância do espaço potencial de cada indivíduo, pois, seja na sociedade, seja no ensino, ou na cultura, é quando cada um contribui com sua criatividade pessoal.

Como lembra Verba (1990), nos jogos de ficção, a criança pode criar de acordo com sua fantasia, mas seu pensamento mesmo estando livre da dificuldade do real, permanece assujeitado na presença do parceiro. Ela pode fazer novas ligações arbitrárias e subjetivas entre os elementos do jogo, modificar regras estabelecidas, pode explorar novas regras e liberar seu pensamento do real, porém de uma forma que se ajuste com o parceiro para que o jogo possa se realizar.

Como já dissemos, Verba (1999) discrimina dois aspectos importantes entre as atividades mentais envolvidas que dão suporte às atividades lúdicas: o aspecto cognitivo e o aspecto imaginário. Assim, verificamos que o primeiro está ligado à manipulação dos blocos e montagem de objetos e personagens, e o segundo, à criação, ou seja, no imaginar situações que constituem o jogo. Como lembra Verba (op.cit), a imaginação nos jogos de ficção é que articula a criação de idéias, as transformações simbólicas dos objetos, personagens, cenários e os encadeamentos das ações. Geralmente a imaginação da criança é alimentada, no jogo de ficção, por intermediários, ou seja, pelo adulto ou por outra criança.

Nas construções simbólicas ou transformações simbólicas dos objetos e nas idéias apresentadas a criança emprega elementos da sua experiência pessoal associados á elementos de sua imaginação. Ao fazer suas construções com o "Lego", ela toma como referente os objetos, cenários, personagens que têm relação com sua experiência de vida e associa elementos que a sua imaginação permite explorar. A atividade imaginária consiste em associar, dissociar, combinar, deslocar e etc. elementos da experiência pessoal, modificando-as de acordo com o interesse no jogo. 
Nos jogos de faz-de-conta, as crianças tornam-se capazes de imaginar, ou seja, ir além da habilidade de pensar sobre sua experiência de mundo e ainda, elaborar sobre o que foi imaginado. Ao fazer de conta, ela faz representações mentais da realidade. É sobre esta capacidade de representar que pretendemos discorrer a seguir.

\subsection{Sobre a representação e o faz-de-conta}

Como foi visto acima, a atividade lúdica possibilita a criança construir representações do mundo, ao mesmo tempo em que, ela apreende as relações simbólicas, conhecimentos e saberes sociais referentes á sua cultura. Alguns estudiosos passaram então a questionar como poderia a ficção auxiliar a criança no seu aprendizado sem se perder no imaginário.

Para Piaget (1975:209), o pensamento representativo inicia-se quando o significante se diferencia do significado. Assim, a formação da representação se explica pela função simbólica, que consiste na diferenciação entre significante (signos e símbolos) e significado (conceitos de objetos e acontecimentos esquematizados) de modo que os primeiros permitam a evocação da representação dos segundos. Para o autor (op. cit:214), o jogo simbólico comporta sua crença própria, subjetiva já que é uma forma de satisfazer diretamente o eu, não sendo, em determinado sentido, verdadeiros para os outros e para a cultura. Assim, o jogo de ficção tem seu crédito, para a criança, simplesmente porque está inserido no universo do eu e tem por função proteger este universo contra as acomodações obrigadas á realidade comum. Para Piaget, (op. cit) este processo ocorre devido ao egocentrismo.

Wallon (1989) também considera a função simbólica como o despontar da representação, referindo-se a esse processo como operação com significações representadas por signos. Para ele, é pelo sincretismo do pensamento da criança que se observa a ficção, revelada no discurso da criança.

Flavell et all (1999) refere que as habilidades simbólico-representacionais mais significativas englobam: o entendimento das representações pictóricas, o uso de modelos físicos e as brincadeiras de faz-de-conta. Ressalta que o faz-de-conta encontra seu período fértil entre dois e seis anos de idade. O autor (op. cit) salienta que, no faz-de-conta a criança evoca a imaginação, cria metáforas, transforma mentalmente objetos e sentidos de 
palavras. Entende que o faz-de-conta pode ser um precursor da mente. Quando as crianças fazem de conta que estão com raiva, bravos, com medo, com fome, elas agem levando em conta estados mentais causais e, portanto elas brigam, dão broncas, choram, comem. Esta atuação mostra que a criança já tem um entendimento sobre as representações mentais.

Astington (2003) mostra que, quando as crianças brincam com o faz-de-conta, elas são capazes de imaginar outra realidade possível. Esta capacidade se manifesta por volta dos 28 meses e se desenvolvem ao longo dos anos seguintes. Crianças de dois anos e meio de idade são capazes de iniciar cenários fictícios e entre três e quatro anos de idade os jogos de faz-de-conta tornam-se mais complexos e criativos, sendo já capazes de representar papéis. As crianças de dois anos de idade participam do jogo de "faz-de-conta", freqüentemente acompanhadas das crianças de mais idade. Elas têm a capacidade de tomar emprestada uma identidade, e fazer de conta que desempenha um papel ou mesmo de dizer a outra pessoa, qual papel ela está representando.

Para Alan Leslie, conforme afirma Astington (2003:56), tão logo as crianças começam a fazer de conta, elas também são capazes de compreender o faz-de-conta de outros. O mais importante desta manifestação é a capacidade das crianças compreenderem os estados mentais de uma outra pessoa e de coordenar sua atividade em relação ao outro. A criança de dois anos de idade está começando a descobrir o mundo e o sentido das palavras. Nesta idade, ao fazer de conta, ela está acumulando um saber, base para construir essa compreensão de simulação, pois, de outra forma, ela poderia ser conduzida a uma distorção da realidade.

Para o autor (apud Astington op.cit:57), o cérebro deve conter um mecanismo inato particular, que permite isolar as simulações do mundo real, que ele chama de "módulo da Teoria da Mente". Esse mecanismo está ligado aos sistemas perceptuais e cognitivos e são os sistemas que permitem formar as representações primárias, ou seja, as representações e as crenças exatas sobre o mundo. As representações secundárias, que seriam as crenças sobre as próprias crenças e sobre as dos outros (esperança, medo, desejos, intenções e simulações), se diferem por não serem submissas à prova da realidade como são as primárias. Quando a representação secundária se encaixa na primária, esta é isolada da realidade. O módulo da teoria do espírito seria exatamente o mecanismo cognitivo que possibilita o encaixe, fazendo com que a representação primária não seja nem verdadeira nem falsa. Assim, os jogos de faz-de-conta são as primeiras manifestações de que este sistema esta operando, que permitem a criança de formar as representações secundárias 
sem que seu sistema cognitivo se confunda. Para ele, este mecanismo cognitivo é inato, mas são as ações e condutas sociais que indicam quando se está fazendo de conta. Mais tarde, esse mecanismo permite formar outras representações secundárias que ele chamou de metarepresentações.

Contrapondo Leslie, Astington (2003:59) cita Perner (apud Astington, 2003) que diz que as representações secundárias da criança de dois anos de idade não podem ser consideradas como metarepresentação, apesar de acreditar que, as crianças dessa idade, possam formar representações secundárias. Para este autor, os jogos de faz-de-conta da criança pequena não indicam o surgimento da representação simbólica, pois com esta idade, ainda não podem compreender a representação. Refere que, uma criança que ainda não compreende que uma coisa pode ser usada para representar outra, ela pode ser capaz de imaginar coisas hipotéticas alternativas à realidade e à ação, mas a compreensão representacional só surge a partir de quatro anos de idade.

Concluindo, podemos observar os diferentes olhares dados para a metarepresentação. De um lado, as metarepresentações são como as representações das entidades representacionais como as crenças em propósito das crenças. De outro lado, elas referem-se à compreensão da atividade representacional considerando seus estados mentais.

Em Gardner (1994:87) é a capacidade metarepresentacional que possibilita a criança tomar uma posição frente à realidade. A metarepresentação é a capacidade de tratar um objeto como se fosse outro, desta forma, nas brincadeiras de faz-de-conta a criança pequena pode pensar sobre sua experiência, imaginar um estado diferente daquele que apreendeu pelos sentidos, como também pode captar certas atividades imaginárias em formas simbólicas socialmente codificadas e a continuar a elaborar sobre essa atividade.

Compreendemos assim que, ao começar a entender as representações mentais do outro, a criança passa a operar com os símbolos e principalmente com a linguagem de uma maneira diferente. Gardner (1994) salienta que, os seres humanos desenvolveram diferentes conceitos e princípios para lidar com o mundo físico, com a tecnologia desenvolvida, com suas máquinas e também, com outros seres humanos que podem adotar diferentes comportamentos ou discursos.

Nesta interação com outros seres humanos é que destacamos as condutas explicativas/ justificativas, pois são condutas sociais, dependentes da comunicação e da 
interlocução e se desenvolvem na interação, quando há diferentes pontos de vista, diferentes crenças, diferentes visões de si e do outro.

Hudelot e Veneziano (2002) propõem que as condutas explicativas /justificativas, quando começam a ser utilizadas pela criança, revelam um início da compreensão de que suas intenções, centros de atenção e conhecimentos poderiam ser diferentes das do seu interlocutor e que, pela linguagem ela pode partilhar representações mentais e construções subjetivas com o outro, além de poder estabelecer relações com um saber-fazer implícito, relativo ao mental do outro. Os autores entendem que as condutas explicativas/ justificativas são de natureza representativa e estão implicadas na capacidade de antecipar o que é suscetível de influenciar o comportamento, as intenções e crenças do outro.

Assim, nos jogos de faz-de-conta, as condutas explicativas/ justificativas estariam relacionadas não só com o saber-fazer, mas também no como cada parceiro pensa o jogo, ou seja, refletindo as intenções e idéias de um, as intenções e idéias do outro.

De certa forma, apesar de ainda não se ter respostas mais contundentes a respeito, o que realmente se sabe, como afirma Astington (2003), é que as crianças, desde cedo, sentem prazer com estes jogos de " faz-de-conta" e manifestam ter certa compreensão deles. Elas são capazes de separar o que é simulado e o que é real, sem confundir com o pensamento. 


\section{CAPÍTULO 2}

\section{LINGUAGEM E PENSAMENTO/COGNIÇÃO:ALGUMAS REFLEXÕES}

\subsection{Preliminares}

Consideramos importante fazermos algumas reflexões e correlações entre linguagem e cognição, recorrendo aos conceitos extraídos das teorias psicogenéticas construtivista e interacionista e teorias lingüísticas, já que nosso objeto de estudo envolve atividade de interação, linguagem e cognição.

Para Piaget (1982), a ação surge do interesse, ou seja, de uma necessidade da criança que pode ser afetiva, fisiológica ou intelectual. A inteligência procura compreender essa necessidade ou interesse de acordo com o grau de desenvolvimento intelectual de seus estágios. Os estágios constituem uma forma particular de equilíbrio que se processam, na evolução mental, no sentido de uma equilibração cada vez complexa. Em todos os estágios têm-se mecanismos funcionais que tendem a: 1) incorporar as coisas e pessoas à atividade própria do sujeito; 2) reajustar as estruturas já construídas e acomodá-las aos objetos externos. Assim, o desenvolvimento mental, segundo o autor ( op. cit), trata-se de uma organização progressiva que busca uma adaptação cada vez mais precisa da realidade. As técnicas e o ajustamento dos meios empregados para tal constituem o aspecto cognitivo.

Lier (1998) mostra que, na teoria piagetiana a ação é estruturante do pensamento, não a linguagem e nem o social. $O$ papel da linguagem é de instrumento para que as operações possam se formular e objetivar. A autora pondera que, para Piaget, a linguagem e o social são responsáveis pela formulação e organização do pensamento e, à ação do indivíduo no meio, a sua construção.

A relação entre pensamento e linguagem se apresenta em planos diferentes na criança e no adulto. Na criança prevalece a subjetividade e no adulto a objetividade. Como analisa a autora (op. cit), Piaget avalia essas diferenças como sendo mais qualitativas do que quantitativas. Enquanto o pensamento na criança é expressivo, subjetivo e intuitivo, no adulto, é mais comunicativo, objetivo e lógico.

La Taille (1992) esclarece que a inteligência, na teoria piagetiana, deve ser entendida como um sistema que se alimenta da ação e da percepção do sujeito, e das 
informações extraídas do meio social e físico, com capacidade de organização destas informações e não somente de acumulador. $\mathrm{O}$ autor (op. cit) enfatiza que a inteligência é fator que depende da ativação social.

Para a teoria piagetiana, nos primeiros estágios há uma indiferenciação entre a criança e o objeto/mundo. Com o desenvolvimento da inteligência, ocorre uma transformação, os objetos passam a ser separados do "eu" e os sentimentos experimentados em função da objetivação das coisas e das pessoas. Com o aparecimento da linguagem, a troca e a comunicação entre os indivíduos se intensificam. A linguagem conduz à socialização e possibilita os atos de pensamento.

Conforme Piaget (1999), até os sete anos de idade as conversas das crianças estão ligadas à ação material propriamente dita. A criança não sabe discutir, só apresentar suas afirmações contrárias. Tem dificuldades de se colocar no ponto de vista do outro. Suas explicações são dadas como que para si mesmas. Falam cada uma por si e consideram que o outro esteja compreendendo. A fala gera uma excitação à ação e não a uma troca de pensamentos reais. A idade de dois a cinco anos é um período de transição entre as duas formas de pensamento: a) pensamento por incorporação ou assimilação pura, ou seja, sem objetividade, dado seu aspecto egocêntrico; b) pensamento adaptado aos outro e ao real, que prepara para o pensamento lógico.

De um ponto de vista um pouco diferente, a teoria walloniana considera o processo de desenvolvimento da criança bastante subjetivo devido às origens afetivas da atividade cognitiva. Para Wallon (1989), o pensamento sincrético como o principal atributo do pensamento infantil, dado seu caráter globalizante. No pensamento sincrético encontram-se misturados o sujeito e o objeto pensado, os objetos entre si, as noções e processos fundamentais do conhecimento de cuja diferenciação depende os progressos da inteligência.

Wallon (1989) compreende que a inteligência é um instrumento individual que auxilia e amplia o desenvolvimento. A inteligência é definida como aptidão para reagir de maneira diferente. Como aponta Dantas (1992), o sujeito, objeto, afetividade e inteligência alternam-se na preponderância do consumo de energia psicogenética. No primeiro ano de vida dominam as relações emocionais com o ambiente. A cognição está latente e ainda indiferenciada da afetividade. É a fase da preparação das condições sensório-motoras (pegar, olhar, andar). No segundo ano de vida, a inteligência se volta à construção da realidade. Quase no final do segundo ano, a função simbólica surge, juntamente com a fala 
e as condutas representativas. Com a função simbólica e a linguagem, o pensamento tornase discursivo.

Assim, diferente a Piaget (op. cit), Wallon (1989) considera a linguagem como instrumento e suporte indispensável para os progressos do pensamento. A linguagem exprime o pensamento e age como estruturadora. A linguagem, ao substituir a coisa, oferece à representação mental o meio de evocar objetos ausentes e de confrontá-los entre si. Os objetos e as situações passam a ter equivalentes em imagens e símbolos e, desta forma, podem ser operados no plano mental de uma maneira cada vez mais desvinculada da experiência pessoal e imediata. Através do processo de simbolização, que possibilita substituir as referências pessoais pelos signos convencionais, o pensamento atinge uma representação cada vez mais objetiva da realidade. Assim, a evolução do pensamento vem da diferenciação entre os conceitos que a cultura fornece. Essa diferenciação leva à diferenciação do eu-outro no plano do conhecimento.

A noção de estágio, ligada à idéia de períodos estanques diferentes entre si e hierarquicamente relacionados, foi bastante questionada. A visão de processo de desenvolvimento em função das experiências comunicativas tomou lugar com o aparecimento das teorias interacionistas. Nesta direção, Vygotsky (1989) propõe que o processo de desenvolvimento é inicialmente organizado e socialmente deflagrado pelo adulto, para ser modificado gradativamente num processo interior de auto-regulação, direcional e seletivo. Para o autor, esse processo ocorre no decurso da história social do homem, na sua relação com o mundo, mediado pelos instrumentos e pelos símbolos desenvolvidos culturalmente e criados na atuação do homem. A operação com os sistemas simbólicos é que possibilita a realização de formas de pensamento que não seriam possíveis sem os processos de representação e a linguagem.

Kohl (1992) mostra que Vygotsky se preocupa com a questão do desenvolvimento da linguagem e suas relações com o pensamento. Como mostra a autora ( op. cit) a linguagem tem duas funções básicas. A primeira é de intercâmbio social: linguagem como sistema que possibilita a comunicação. Para tal, é necessário usar signos que sejam compreendidos socialmente. A segunda função da linguagem é a de pensamento generalizante. A linguagem ordena o real agrupando em categorias conceituais. Assim, a linguagem fornece os conceitos e as formas de organização do real que constituem a mediação entre o sujeito e o objeto de conhecimento. A linguagem tem função de 
comunicação, de simplificar e generalizar a experiência ordenando as instâncias do mundo real em categorias conceituais cujo significado é compartilhado socialmente.

Nesta perspectiva, o aprendizado ocorre da interação do par mais competente com o menos competente. A experiência comunicativa que a criança vivencia com o adulto (experiência linguageira e lingüística), quando se internaliza, passa a ser utilizada como instrumento do pensamento. Na cultura é que criança e adulto em interação negociam e informam conceitos e significados num processo constante de recriação e reinterpretação.

Como explica Kohl (1992:30), esta operação se realizada pela "palavra". As formas culturais internalizadas se constituem no material simbólico que possibilitam a mediação entre o sujeito e o objeto de conhecimento. As palavras designam as categorias culturalmente organizadas e a linguagem passa a representar essas categorias e a funcionar como instrumento de organização do conhecimento. "O significado é componente essencial da palavra e ao mesmo tempo, um ato do pensamento, na medida em que o significado de uma palavra já é em si uma generalização." (Kohl,1992:80).

Neste sentido, pensar a relação entre pensamento e palavra se constitui de um processo dinâmico e contínuo que passa por transformações que, em si mesma, pode ser considerado um desenvolvimento no sentido funcional.

As abordagens cognitivistas apresentam seu ponto de vista com relação á linguagem, ao seu desenvolvimento, como construção e apropriação da fala do outro, mas não respondem á questões relacionadas á diversidade da língua e seus modos de significar, como aparecem as variações na língua e etc.

Possenti (2003) descreve sucintamente as abordagens da lingüística a respeito da linguagem e da língua. Primeiramente, o autor se dirige á linguagem como um sistema tão complexo "que não há teoria ou modelo que dê conta de todos os seus ângulos" (Possenti, op.cit: 362). Como discute o autor, as línguas não são sistemas internamente uniformes, são passíveis de variações (fonológicas, morfológicas, sintáticas, lexicais etc), que podem ser responsáveis pela constituição da identidade dos falantes e, às vezes, podem ser confundidas como erro. Segundo, as palavras ou seqüências de palavras são polifônicas, isto é, não se garante sua interpretação unívoca, pois há fatores lingüísticos, pragmáticos e discursivos envolvendo a significação. Terceiro, a língua não é um código e, portanto, seu funcionamento não é automático, exige uma atividade dos interlocutores que implica na avaliação e seleção de quais fatores devam ser considerados em cada ato de fala, que inferências e correlações pragmáticas precisam ser realizadas e também que saberes e 
memórias necessitam ser acionados para que se tenham interpretações mais ou menos adequadas ás diversas situações.

A partir destas teses, verificamos que a diversidade da e na língua, as variações lingüísticas, o erro não podem ser entendidas nas abordagens cognitivistas que consideram a mudança como algo a ser substituído, sem compreender como fora produzido. Em suas reflexões, De Lemos (2003) aponta que, destas abordagens derivam uma pragmáticas cognitivista que considera a comunicação sempre bem sucedida, que separa a fala da linguagem para isolar a língua e caracterizá-la como objeto de estudo. Como explica a autora (op. cit: 523), estes estudos analisam a linguagem e a comunicação a partir da determinação do conhecimento sobre o ato visto como comportamento, correspondendo a estados mentais à suas instanciações externas.

Para De Lemos (op.cit: 523,524), o modelo psicanalítico freudiano apresenta um conceito de representação que subverte qualquer espécie de correspondências entre palavra e coisa, pensamento e linguagem, não associando a um conhecimento. Assim, os erros e variações são produzidos pelos processos metafóricos e metonímicos, responsáveis tanto pelo erro quanto pela (re) significação e estabilização destes movimentos. Esclarece que essas mudanças não podem ser qualificadas como construção de conhecimento e nem desenvolvimento e sim, como captura do funcionamento de uma estrutura de funcionamento da linguagem. Propõe uma trajetória da criança na aquisição e desenvolvimento da fala baseada na mudança de posição em uma estrutura, marcada pela posição da criança relativa á fala do outro, relativa á própria língua e seu domínio funcional e, pela relação do sujeito com sua própria fala. É nesta posição, em que o sujeito "enquanto falante se dividiria entre aquele que fala e aquele que escuta sua própria fala, sendo capaz de retomá-la, reformulá-la e reconhecer a diferença entre sua fala e a do outro, assim como as instâncias subjetivas da sua fala e da escuta de um outro". (De Lemos, 2002:57).

As variações da fala da criança, o erro ou os enunciados incomuns podem levar a uma interrupção da interação que, como aponta Castro (2003, 472), pode solicitar a interpretação. Essa interpretação pode ser entendida como uma tensão entre o reconhecimento de uma língua e um estranhamento pelo erro surgido no enunciado ou por necessidade de uma (re) significação no possível da linguagem. Como diz François (1996: 47) "se há interpretação é porque o mesmo objeto pode ser visto e tocado, depois visto e dito pelo outro, depois dito pelo outro e dito por mim". Neste contexto é que a fala da criança se submete ás estruturas próprias da argumentação. 
Como comenta Possenti (2003), a linguagem não serve apenas para comunicar mensagens ou transmitir pensamentos e informações, mas também para estabelecer relações pessoais, para convencer, agredir, brincar. Não há formas corretas e incorretas de falar, há formas mais adequada e menos adequada.

O que podemos verificar é que, tanto entre lingüistas quanto as abordagens cognitivistas e interacionistas concordam que as formas lingüísticas não subsistem separadas dos fatores culturais, sociais e históricos.

Compreendendo assim, estas funções da linguagem, identificamos as seqüências explicativas na fala da criança, particularmente no contexto de faz-de-conta. $\mathrm{Na}$ necessidade de informar, de (re)significar os elementos do jogo, de articular idéias e proposições com o outro, e etc, a criança faz uso da linguagem produzindo explicações e justificações. A explicação/ justificação da criança envolve, portanto, as suas marcas interpretativas do mundo.

Veneziano e Hudelot (2002:233) revelam que as condutas explicativas/ justificativas são condutas iminentemente sociais, dependentes da comunicação e da interlocução que contribuem ao desenvolvimento de um saber-fazer e de saberes sóciocognitivos. Assim, a partir destas correlações, é que articulamos as condutas explicativas justificativas no jogo de fícção, como condutas provenientes da interpretação entre os interlocutores e da explicação e justificação como uma forma de usar a linguagem para a partilha de significações.

\subsection{O discurso explicativo: em torno da argumentação}

Como o enfoque deste estudo está nas seqüências explicativas produzidas pela criança, é primordial buscarmos inicialmente uma definição de explicação. Uma série de pesquisadores, sob diferentes abordagens, discutem o que é explicar, quando se explica, porque se explica e como se explica, mostrando que há fronteiras delicadas entre o justificar, explicar um fato, motivar, esclarecer, informar e etc. Um ponto comum entre os autores: explicar é fazer o outro compreender.

Borel (1981) indica dois aspectos distintivos para o que é explicar. Explicar como sendo uma atividade do conhecimento e explicar como atividade de linguagem, na qual a explicação é vista como objeto do pensamento, possuindo regras próprias e lógicas 
internas. Compreende a explicação como um tipo de discurso pelo qual a enunciação segue propriedades semânticas que permitem a linguagem de dar significados.

A autora considera o discurso explicativo um gênero de discurso estreitamente ligado à argumentação. Destaca alguns aspectos: explicar exige um distanciamento do locutor, ou seja, uma descentração para se reportar aos valores e tornar-se observador; e a explicação deve responder a um problema especifico em que se supõe um explanandum (aquilo que deve ser explicado) e um explanans (aquilo que explica).

Como salienta ainda a autora (op.cit 1981:25), a explicação depende das condições na qual é solicitada e de sua finalidade. Desta forma, se constitui de uma dimensão interacionista e outra dimensão cognitiva. Uma, está ligada à comunicação e, a outra, á racionalidade respectivamente. $\mathrm{Na}$ dimensão interacionista explicar: pode ser: comunicar (formular, expor, expressar); ensinar (fazer compreender); justificar (motivar, desculpar-se, legitimar). Na dimensão cognitiva explicar pode ser: explicitar no sentido de desenvolver (definir, criticar, comentar); explicitar no sentido de interpretar (elucidar, traduzir, situar, reconstituir) e como explicar (dar as razões de, prestar conta). As duas dimensões estão freqüentemente associadas a uma função de "fazer compreender".

A autora conclui que a explicação envolve um processo cognitivo manifestado simultaneamente a um processo de comunicação. Comunicação entendida como circulação e troca de informações que se operam a partir de desejos, crenças, e das decisões dos interlocutores e que são expressas pela linguagem. Na medida em que, a explicação pode contribuir para a tomada de decisão, estabelecendo um posicionamento ou uma avaliação, é que a autora considera a explicação ligada ao discurso argumentativo, lembrando que a diferença entre explicação e argumentação está no produto.

Em Grize (1981:40), temos que um argumento se constitui nas justificativas utilizadas com intuito de intervir na opinião do outro. A argumentação se refere ao discurso que implica o outro ao nosso ponto de vista. Para o autor (op.cit), argumentar é uma atividade do pensamento se remete a justificar, explicar. É modificar as representações do outro evidenciando certos aspectos dos objetos e propondo novos inseridos em uma esquematização apropriada.

Ducrot e Ascombre (1988) lembram que a argumentação se inscreve na própria língua dada à natureza argumentativa da linguagem. Neste ponto de vista, a linguagem é considerada não só um instrumento de informação, mas basicamente de argumentação. 
Para Meyer (apud Carrilho 1994:17), a argumentação é a negociação da distância entre os sujeitos que tem sua raiz num problema que se processa na linguagem. Para o autor, a argumentação está presente na situação de interlocução sob duas dimensões: no domínio da troca e as circunstâncias pragmáticas. A situação de interlocução impõe uma interpretação, um sentido no conjunto de valores que os termos adquirem, numa rede de significados e que interpretados, reconstruirão a significação, a relação entre as palavras e o conceito de coisa ou a coisa.

Borel (op.cit) correlaciona estas propriedades da argumentação ao discurso explicativo. Inscreve a explicação numa organização de informações formulada nos enunciados na língua natural e que a explicação não compreende marcas dedutivas, mas sim marcas interpretativas sustentando a pesquisa das hipóteses explicativas.

A autora ressalta que as marcas interpretativas que intervêm na construção do objeto de conhecimento, ou seja, um elemento de significação interacional que intervém como momento de significação cognitiva, não é mais retórico. Por este ponto de vista, a autora mostra que o discurso explicativo caracteriza-se por uma articulação especifica entre fatos/objetos que aparecem numa situação interacional e privilegia a sua significação cognitiva. Neste contexto, os interlocutores divergem em suas opiniões e apresentam pontos de vista diferentes em relação ao fato/objeto de interesse comum.

$\mathrm{Na}$ comunicação, a explicação se apresenta como uma esquematização de um objeto de conhecimento. Desta forma, o discurso não mais segue em direção dos agentes e das significações das ações como a argumentação retórica, mas em direção ao objeto. "A verdade é dita a respeito do objeto, se diz algo a respeito do objeto, de qualquer coisa, e não mais para qualquer um ou qualquer coisa" (Borel, 1981).

Contrastando o discurso explicativo ao discurso argumentativo, Borel (1981) acrescenta que a explicação sempre comporta um elemento dialógico (mesmo quando com um componente de justificativa). Entende que explicar é um tipo de comunicação instaurada numa interação conflituosa, mas isenta de uma situação polêmica característico da argumentação. Como refere à autora, o discurso explicativo na criança, surge nos fragmentos discursivos que contribuem para a compreensão dos fragmentos da experiência.

Partindo da noção de que explicar é "fazer compreender para agir", "é fazer o outro compreender", Halté (1988) enfatiza que o discurso explicativo surge quando uma interrupção da compreensão aparece numa dada situação e a perturba. Entendendo que na comunicação, o discurso é uma forma de intermediar a interação, de conduzir e orientar os 
interlocutores segundo seus objetivos, o discurso explicativo surge neste contexto, num momento que algum fenômeno não é compreendido, confundindo e interrompendo a interação. Com a finalidade de restabelecer a interação, o discurso trata o fenômeno intrigante de forma objetiva, buscando a compreensão deste, a fim de restabelecer a interação anterior. Halté (op. cit., 1988:5) aponta também que, dada sua especificidade no fluxo comunicacional e dada sua função, o discurso explicativo faz-se objeto de negociação entre os protagonistas.

Borel (1981:23) ressalta que o discurso explicativo não é uma realidade tomada isoladamente, fora de seu contexto e das relações com outros discursos, da situação que o determina. Sua função explicativa pressupõe um saber necessário sobre o objeto e sobre a relação do outro com objeto e as condições sociais que o legitima. Os interlocutores assumem papéis de propositor, como aquele que sabe do requerente, aquele que não compreende e que leva o outro a explicar. Portanto, emerge na assimetria dos estatutos e dos saberes e em seu desenvolvimento assinala, num segundo momento, a simetria.

Para Coltier (1989), duas situações favorecem a produção do discurso explicativo: a) quando numa situação surge um problema da ordem do saber; b) quando um agente comunica sua proposição com o intuito de modificar a percepção que os outros tem do real, trata-se de um fazer compreender. Em ambas as situações o discurso explicativo pode surgir em forma de questões, que nem sempre são formuladas por meio de uma interrogativa direta.

Outro traço característico do discurso explicativo, segundo Coltier (op. cit.), é transformar o fenômeno problemático em um fenômeno comum. Dois procedimentos podem ocorrer: a) o discurso explicativo mostra a complexidade da representação do fenômeno a explicar. Partindo dos saberes anteriores, a explicação agrega novos elementos permitindo estabelecer uma nova relação entre o conjunto de conhecimentos e o objeto enigmático; b) modificar o todo ou parte dos saberes anteriores. Explicar aqui consiste em recusar todo o valor dos saberes admitidos, justificar a rejeição desses saberes e propor um sistema diferente de representação do fenômeno.

Como conclui a autora (op. cit), problematizar um objeto, apontar uma resposta suscetível de modificar um sistema de representação e transmitir através do discurso, de forma racional e adaptado a um enunciatário específico, são propriedades do discurso explicativo, sob no ponto de vista lingüístico. 
Veneziano, Favre e Berthoud-Papandrolou (1990) enfatizam que a explicação não apresenta necessariamente, marcadores lingüísticos específicos. Consideram o ato explicativo como um fenômeno interacional, no qual o locutor: 1) identifica um explanandum, ou seja, um acontecimento, ação ou ato comunicativo do qual se é preciso explicar ao interlocutor ou por solicitação ou por suposição desta necessidade. 2) e um explanans, ou seja, a causa ou razão ou justificação deste acontecimento ou ação.

$\mathrm{O}$ ato explicativo pode se apresentar na enunciação das seguintes maneiras:

* O explanans é verbalizado e o explanandum aparece não-verbal;

* O explanandum e o explanans são verbalizados, mas esse último é produzido em um segundo tempo, após um turno de fala do adulto;

* O explanandum e o explanans são verbalizados em um mesmo turno de fala ou em dois turnos de fala sucessivos, sem intervenção do adulto entre eles.

Segundo a ótica de que a explicação aparece como forma de modificar as representações do outro, ou seja, de fazer o outro compreender para agir, alguns estudiosos passaram a estudar a explicação na fase de desenvolvimento, implicada num quadro funcional e interacional. Assim, o ato explicativo por se referir a comportamento, ou seja, a condutas que envolvam atos de explicação e justificação, os autores denominaram de condutas explicativas/ justificativas. (Veneziano, Favre e Berthoud-Papandrolou,1990; Hudelot, 1997; Hudelot e Veneziano, 2002).

Hudelot, Préneron, Salazar-Orvig (1990, trad. 2003), lembram que as condutas explicativas/justificativas se constituem de encadeamentos discursivos que apresentam relação de significado manifestada pela co-articulação, de pelo menos, dois enunciados centrais. Os encadeamentos manifestam ao mesmo tempo uma relação de conteúdo (especificação, explicação, explicitação, justificação, refutação) e uma relação com o outro. Assim, se poderia dizer que as condutas envolvem uma dimensão pragmática, no sentido de que a troca recai sobre uma atividade essencialmente prática ou em interação e uma dimensão discursiva, na qual os encadeamentos recaem na adequação de uma codificação, ou seja, no compartilhar de significações (Melo, 2003). 
A partir destas concepções, assumiremos a atribuição dos rótulos "condutas explicativas/ justificativas" (CEJ) ás seqüências de explicação produzidas pela criança, como objeto de estudo desta pesquisa.

\subsection{A explicação na criança a partir de diferentes olhares.}

Para Piaget (1999) e Wallon (1986), a criança dá explicações a partir do processo de indiferenciação, ou seja, de diferenciar sujeito do objeto. Piaget (1999) refere que esse processo ocorre pela descentração, ou seja, perceber o outro e perceber o mundo pelo ponto de vista do outro. Este aspecto peculiar do pensamento da criança de ser centralizado sobre eu próprio ponto de vista, é que Piaget (1999) denomina de egocentrismo. Como aponta La Taille (1992), o "eu" é construído juntamente com a noção de outro num processo de diferenciação. Egocentrismo significa que a criança ainda não tem domínio sobre seu próprio eu e que ainda é heterônoma no seu modo de pensar e agir, por isso este teórico não considera a interação social como fator desencadeador da comunicação e da linguagem. Por isso, as explicações da criança, até a idade de sete anos, são dadas como que para si mesmas. Cada uma, fala por si e considera que o outro esteja compreendendo. Para ter objetividade é necessário passar da indiferenciação inicial dos pontos de vista para uma diferenciação por descentração quando, então, suas explicações passariam a ter mais objetividade. Como salienta Castro (1996), a causalidade e as operações, na teoria piagetiana estão em constante interação a cada estágio do desenvolvimento. "Sua fonte comum é a ação e, é somente no decorrer do desenvolvimento que se procura simultaneamente a diferenciação e a colaboração entre eles.” ( Castro, 1996:49)

Numa visão diferente, Wallon (1986) enfatiza que a criança não passa por uma fase de egocentrismo, mas de sincretismo. O pensamento sincrético se caracteriza pela indiferenciação entre sujeito e objeto a nível discursivo, mas não por a criança ser autrocentrada.

A noção de causalidade vem da própria atividade da criança e de suas experiências com o mundo. Inicialmente a criança classifica os objetos segundo sua atividade ou sua percepção e sensação e a causalidade é percebida em relação à ação da criança em seu mundo. Num segundo, as atividades estão centradas no exterior, nos objetos externos. Portanto, a criança cria impressões, rotinas e, a partir da representação, ela ordena-as, 
selecionando diferenças e semelhanças, identificando e classificando em categorias. Nas situações vividas, ela irá estabelecer a relação entre causa e efeito. A partir dos cinco anos de idade, a criança desenvolve a função categorial, período em que passa a organizar o real em séries e classes possibilitando a análise, síntese, generalizações, e comparações. O conteúdo das explicações, nesta fase, é essencialmente baseado no conhecimento da criança e de suas criações. As explicações da criança partem de um ponto de vista próprio até que ela tenha desenvolvido habilidades para ver o mundo de maneira não mais subjetiva, mas objetiva, percebendo as relações de causa e efeito direcionadas ao fato em si, e não às suas experiências e aos seus registros empíricos.

Na teoria de Wallon (1986), o momento de indiferenciação ocorre quando a criança passa o ter mais objetividade, ou seja, quando reduz a fase de sincretismo e inicia a fase categorial. O pensamento sincrético é constituído em pares, duas idéias fundidas de maneira indissociável, que se associam independentemente de sua significação objetiva.

Os fenômenos típicos encontrados no pensamento sincrético são fabulação, tautologia e elisão. Entende-se por tautologia quando se explica um termo pela repetição do mesmo; "telepatia é um bicho que tem telepatia". Indica os primeiros sinais de que a criança busca uma coerência intelectual, tentando experimentar alguns elementos de objetividade. Dizer que "uma mesa é uma mesa" é uma fórmula, cuja significação pode reduzir estritamente o objeto designado ao de sua definição ou que seu conceito permite esperar. A tautologia pode ser uma tomada de consciência. Apesar de rudimentar, o pensamento tautológico está no caminho da abstração. É uma identificação de algum modo estática, mas já representativa. Na tautologia, o pensamento da criança permanece intermediário ente a explicação e a particularidade identificada.

- A fabulação é quando a criança inventa uma explicação original e intencional por desconhecer objetivamente o significado do conceito. No exemplo, "o bicho" como vetor da "telepatia". A fabulação é uma atividade lúdica, faz parte de suas atividades naturais. Não é uma explicação controlada e nem esperada pelo adulto. Interessante observar que a fabulação não resulta do excesso de criatividade e nem pode ser vista como uma forma de explicação ou de compreensão facilmente acessíveis, pois como acentua o autor, revela uma fraqueza particular das condutas intelectuais. Pode se aproximar de uma fuga de idéias, pois possibilita uma dispersão nas conversas ou nos atos. A fabulação pode tornar-se fonte de novas associações e pode aparecer como idéias desordenadas e o conjunto ficar contraditório. 
- A elisão ocorre quando a criança omite alguns termos, dando a impressão que falta partes. Parece uma fala confusa, que ocorre quando prevaleceu algum outro critério, como o afetivo, por exemplo, sobre os lógicos e objetivos. Essa característica se faz presente também nas definições e explicações do real (Melo, 2003).

Para Wallon (1989), explicar é estabelecer as condições de existência. Ao dar explicações, as crianças têm como base a sua experiência vivida e a sua percepção direta. $\mathrm{Na}$ fase pré-conceitual, fase que começa a reduzir o sincretismo, a função da inteligência é o de explicar a realidade. Explicar supõe definir. Definir é fazer a atribuição das qualidades especificas de um objeto, integrando-os em uma classe maior e diferenciando-os. Diferenciação e integração constituem os processos básicos envolvidos, que permitem subtrair os objetos da confusão sincrética, e estabelecer entre eles uma rede de relações que constituirão as explicações das coisas. Enquanto não houver esse processamento, o pensamento binário permanecerá e manterá o sincretismo.

Para o autor (op. cit), as capacidades de pensamento da criança podem ser observadas a partir das explicações que ela dá aos objetos e eventos do mundo. Compreender ou dar explicações é ser capaz de fazer ou compreender a pergunta correspondente. A criança só faz perguntas por curiosidade pessoal ou quando o objeto solicita, porém não sabe fazer quando pressionada. As crianças reagem às perguntas ouvidas quando estas apresentam um motivo que possam associar a alguma afirmação.

Conversas com criança sobre objetos que não the interessam imediatamente, tornam-se possíveis por volta de cinco anos e meio e seis anos de idade. Antes dessa idade, a atividade pode ser suscitada, mas não dirigida, pode ser descrita, mas ainda é uma atividade ligada às situações afetivas ou práticas, complementar aos objetos manipulados ou desejados e das pessoas de quem a criança espera ou exige algo. É a atividade que a criança manifesta em seus jogos e em suas tentativas de imitação. Essa atividade é marcada por alternância de objetividade e de manifestações afetivas. A criança pede para ser observada no que faz. Sua atuação oscila entre a manipulação, as efusões afetivas, a colaboração gestual, a oposição. No plano da conversação pode-se perceber que a sua colaboração com o interlocutor mostra a maneira pelo qual se estabelece o contato e a influência disso em suas repostas. Às vezes, responde com total silêncio e, às vezes, coloca-se numa situação de oposição (Wallon 1986).

As reações de oposição refletem a vontade da criança em recusar a solicitação do interlocutor adulto. A oposição pode modificar a pessoa do interlocutor. Outras vezes a 
oposição resulta de uma situação que perturba a criança, por ser totalmente desconhecida para ela, de forma que ela não tenha uma resposta fácil e espontânea, portanto, silencia. A oposição também pode ser conseqüência de uma confusão criada pelas pessoas que interagem com ela e como ela. Como ainda não controla bem suas atitudes, reage dessa forma. São reações de oposição ou de inibição favorecidas ou modificadas pelas circunstâncias. As manifestações de ignorância podem também se tornar lúdicas. É freqüente, em um jogo, a criança fingir que não sabe o que é, sendo que no fundo, ela sabe que sabe. A ignorância simulada pode ser um jogo ou uma oposição, que estão ligados a certos objetos ou certas perguntas. Wallon (1986) mostra vários exemplos como: "Como é que fica de noite?" Não sei. "O que é noite?" Não sei. "Você não sabe o que quer dizer ficar de noite?" Não, não sei. "E de dia?" Não, não sei.

Respostas de contorno são ora acidentais, ora sistemáticas. Parece que a criança faz um jogo de furtar-se às perguntas do adulto através de respostas engraçadas. Ora é malícia, ora é divertimento, ora reflete falta de vontade.

Ex.: "você gosta do mar?" Eu já fui tomar banho lá. "Você gosta de tomar banho de mar?" Ele me lava e me deixa limpo. "Você já bebeu água do mar?" Não. (Wallon, 1986).

$\mathrm{O}$ autor refere-se também à inércia intelectual que, nas primeiras manifestações, dificulta a cadência do adulto, causando discordâncias nas conversas. Disso decorre o atraso das respostas das crianças, o que parece um contra-senso, pois estas se relacionam não à questão precedente, mas a penúltima ou antepenúltima. Com a descontinuidade presente no pensamento da criança, ela não pode manter sua atenção, no mesmo objeto, por muito tempo, dado a incapacidade para conservar, por tempo maior. A acomodação mental gera, assim, um rápido esgotamento de seus atos psíquicos. A descontinuidade tem, portanto, como contrapartida, a persistência, que se pode verificar nas repetições. Essa reação de descontinuidade e repetições pode parecer uma má vontade, embora tenha sua origem numa inaptidão fundamental, na qual outro efeito é o da não evocação das imagens que as circunstâncias ou os termos da conversa deveriam suscitar. $\mathrm{O}$ fracasso da criança pode parecer uma recusa ou uma oposição. Quer seja uma inércia de má-vontade ou de incapacidade, existe uma associação freqüente. A persistência de uma palavra pode levar á incoerências, contradições, justaposições, pensamento descontinuo que pode gerar as digressões.

Kohl (1992:80) mostra que, na teoria de Vygotsky, a criança ao tomar posse dos significados, ela os aplica em seu universo de conhecimentos sobre o mundo, num modo 
todo particular de "recortar" a experiência. Através da interação entre adultos e outras crianças mais velhas ela vai ajustando seus significados de modo a aproximá-los cada vez mais dos conceitos determinados cultural e lingüisticamente ao grupo a que pertence, transformando-os e tornando-os cada vez mais próximos dos conceitos estabelecidos pela cultura. A autora ainda nos remete a dois componentes distintos do significado da palavra: o significado propriamente dito e o sentido. O significado propriamente dito refere-se ao sistema de relações objetivas que se formou no processo de desenvolvimento da palavra, consistindo num núcleo relativamente estável de compreensão da palavra e compartilhado por todas as pessoas que a utilizam. O sentido refere-se ao significado da palavra para cada indivíduo, composto por relações que dizem respeito ao contexto de uso da palavra e às vivências afetivas do individuo. $\mathrm{O}$ sentido da palavra liga seu significado objetivo ao contexto de uso da língua e aos motivos afetivos e pessoais de seus usuários. Assim, as explicações da criança, aqui, serão reflexos da experiência que tem do mundo e dos significados que ela apreende na interação com o outro.

Várias pesquisas, com base nestas concepções abordadas, vêm mostrando que as crianças, desde pequenas, podem dar explicações. Portanto, as seqüências explicativas produzidas na fase de desenvolvimento da criança, além de refletirem sua experiência, fazem parte de um processo mais amplo de mediação cultural e social que ocorre na interação, através da linguagem.

\subsection{As condutas explicativas /justificativas na situação de jogo de ficção}

Hudelot (1997), Dubost (1999), Veneziano e Hudelot (2002) identificam as condutas explicativas/ justificativas na interação a partir dos seguintes critérios:

* Primeiro: locutor faz referência às duas partes da explicação: o explanans (o que explica) e deve ser verbalizado e o explanadum (o que é explicado), que pode aparecer marcado verbalmente ou não, podendo ficar implícito.

* Segundo: a verbalização, ou seja, o explanans deve ser dirigido ao outro e assumir um espaço próprio, não deve se confundir com a "colocação em linguagem" de uma ação ou evento. Deve fornecer a causa, a razão ou motivação do explanandum. 
* Terceiro: o evento pelo qual a explicação é fornecida pode ser considerado pelo interlocutor como qualquer coisa que pede para ser explicada, deve responder a um "por que" solicitado de modo explícito ou implícito.

Segundo Mollo e B-Berthoux (1999), as seqüências explicativas que surgem na situação criança - adulto em situação de jogo podem aparecer como motivação do agir e como explicação propriamente dita. A explicação propriamente dita comporta duas categorias distintas: a) a que trata da regulação do jogo, ou seja, o ato linguageiro serve para explicar e possibilitar a gestão do jogo; b) o ato explicativo não tem pretensão de influir no jogo, e sempre responde a um "porque" do adulto, ou o adulto induz um comportamento dialógico particular, visando produzir uma explicação. São contribuições do adulto e, geralmente, se relacionam com a gestão dos saberes ou visam explicitar, dar suporte à informação e criar intervenções para a gestão de ações. Assim temos:

- Regulação: $1^{\mathrm{a}}$ categoria da explicação - se relaciona à gestão do jogo.

- Explicação: $2^{\mathrm{a}}$ categoria de explicação - se relaciona à gestão dos saberes.

Essas distinções envolvem processos diferentes, tanto do ponto de vista lingüístico, comunicativo, como cognitivo.

As autoras também distinguem a categoria "comentários" relacionada á gestão dos afetos, como motivação do agir. Essa categoria traduz os sentimentos, as emoções que surgem durante do jogo ou fazem a descrição do que se passa. Podem ser espontâneos, ou dados em resposta a outras intervenções. Revelam o prazer e o não prazer no transcorrer do jogo. As autoras ainda estabelecem diferenciação entre "comentário" e "regulação". Os "Comentários" se dirigem ao aspecto dominante de responder uma questão e, a "Regulação", ao aspecto dominante de realizar uma intervenção sobre o agir no jogo. A categoria "explicação" é sempre determinada pela resposta a um "por quê" explícito ou induzido pelo diálogo.

Para Veneziano, Favre e B. Papandrolou (1990), os conteúdos das explicações (explanans) produzidas pela criança, recai sobre aspectos diferentes: a) sobre sua incapacidade de efetuar a ação; b) sobre características da ação a ser efetuada ou do objeto; c) sobre estados internos; d) sobre as intenções e planos alternativos de um futuro imediato; e) sobre a avaliação da criança na situação ou na ação. Segundo Veneziano (2003), as 
explicações que surgem a respeito de estados internos estão relacionados principalmente, mas não só, ás situações de jogo de ficção, quando a criança atribui intenções ou estados internos aos personagens fictícios.

Conforme Dubost (1999), as situações e eventos que a criança considera como explananda, ou seja, as situações/ eventos que devam ser explicados ao seu interlocutor são essencialmente de três tipos: as oposições, os pedidos e as requisições, e a ação propriamente.

Verba (1990) também constata que, nos jogos de ficção partilhada, a comunicação exerce um papel fundamental nos três aspectos constituintes: a) sócio-afetivo que engloba o estabelecimento e a manutenção da interação; b) o criativo que envolve a partilha; e c) na gestão do jogo, que envolve sua progressão. A autora (op.cit) revela que para haver compreensão mútua entre os parceiros, dois processos são identificados: a transmissão de informação e a confrontação. A transmissão se dá principalmente pela denominação dos significados. A denominação pode aparecer acompanhada de complementos da informação ou por solicitação do parceiro. Na confrontação é quando os parceiros comparam seus pontos de vista e suas representações e buscam um ajustamento. Entendemos que, neste contexto, as condutas explicativas / justificativas apresentam seu papel fundamental para o desenrolar dos jogos de ficção.

Como podemos notar a conduta explicativa/ justificativa da criança manifesta-se implicitamente ou explicitamente, espontaneamente ou provocada pelo adulto. A conduta tutelar do adulto, no jogo de faz-de-conta, exerce um papel de desencadeador de explicação/ justificação. O intuito é fazer o jogo progredir, estimulando a partilha e a negociação de sentidos. Algumas vezes, a criança introduz idéias, tanto para construir elementos (objetos personagens, cenários) quanto para propor eventos e ações e, apresenta explicações e justificações já com intuito de fazer o adulto aceitar esta proposição dada. Geralmente, é o adulto que conduz a criança, estimulando-a a explicar ou justificar as proposições dadas ou possibilitando a negociação de proposições. Assim, neste momento, interessa nos então, estabelecer correlações entre as condutas explicativas / justificativas da criança e a tutela do adulto, aspecto que será discutido a seguir. 


\section{CAPÍTULO 3}

\section{EFEITOS DA TUTELA NA CONDUTA EXPLICATIVA/ JUSTIFICATIVA EM SITUAÇÃO DE JOGO DE FICÇÃO}

\subsection{Preliminares}

Em Vygotsky (1984), o desenvolvimento e o aprendizado decorrem da interação entre criança e adulto ou um par mais competente, denominando tutela, esse tipo de interação. Essa noção tem como base o conceito de Zona de Desenvolvimento Proximal, que se refere à:

[...] distância entre o nível de desenvolvimento real determinado pela solução independente de problemas realizada pela criança e, o nível de desenvolvimento potencial, determinado pela solução de problemas sob a orientação de um adulto ou em colaboração com companheiros mais capazes. (Vygotsky, 1984).

Sob esta perspectiva, muitos estudos surgiram buscando compreender o papel do adulto nos processos de internalização de conhecimento em função do aprendizado e desenvolvimento da criança. Bruner (1991), baseando-se na perspectiva vygotskyana, conclui que as representações do mundo são, em grande parte, constituídas pelas regras socioculturais, pelas convenções da linguagem e pelos sistemas semióticos. Propõe então que uma teoria do desenvolvimento deve seguir um modelo que possa compreender o aprendizado da criança na interação.

A posição de Bruner (op.cit) sobre o estudo da cognição é mais interpretativa, na medida em que ele se interessa pela "produção de significados".. Como refere o autor (op.cit), o meio de vida culturalmente adaptado depende da partilha de significados e conceitos, de modos compartilhados de discurso para negociar diferenças de significação e de interpretação. Entende que o significado é determinado pelas formas de conduzir as ações de acordo com a cultura que está inserido. Portanto, é necessário entender como as experiências e ações são moldadas por atos intencionais e como esses se realizam através da sua participação em sistemas simbólicos da cultura. Cada cultura espera que seus 
membros tenham comportamentos apropriados ao cenário na qual elas inserem, de acordo com a situação ou com seu papel representado (Bruner, 1991:41).

Assim, no jogo de ficção partilhado, algumas formas de manusear os elementos do jogo, de encadear ações e idéias são esperadas pelo parceiro, dado este determinante cultural. Quando não se segue esta rotina, os parceiros precisam significar os elementos, ações e idéias e buscar aceitação do outro. Um parceiro pode recusar, modificar ou aceitar integralmente as propostas, idéias, significações e sentidos apresentados pelo outro parceiro.

As crianças, ao fazerem uso da linguagem, se tornam capazes de captar significados. Para Bruner (1991), o significado simbólico depende da capacidade de interiorizar a linguagem e usar seu sistema de sinais para interpretar. Para o autor, a criança, mesmo antes de dominar a linguagem, desenvolve habilidades comunicativas generalizadas que posteriormente seriam incorporadas à fala. Essas habilidades se relacionam às funções $\mathrm{e}$ intenções comunicativas como a atenção conjunta frente ao referente, revezamento no falar, troca mútua etc. Para adquirir a linguagem, a criança requer assistência das pessoas que cuidam dela e de sua interação para aprender o que dizer, para quem, em que circunstâncias etc. Sua abordagem enfoca a função da linguagem, pois o autor acredita numa aptidão inata pré-lingüística para o significado que será dominado pela participação da linguagem como instrumento de comunicação.

Acreditando no envolvimento deste mecanismo inato de aquisição de linguagem e que este mecanismo é estimulado pela interação com o outro, Bruner $(1987,1991)$ propôs o LASS (sistema de Suporte de aquisição de linguagem), especificando formas de interação que permitam esse processo. Define tutela como o conjunto das intervenções ocorridas entre o adulto e a criança que favorecem a realização de uma tarefa na qual a criança não conseguiria realizar sozinha. Nesta condição, o adulto assume certas atitudes como induzir, manter a direção da orientação, apontar, controlar frustrações, encorajar a criança a finalizar a tarefa etc., com intuito de auxiliar a criança na aprendizagem.. O termo "tutela", então, começou a ser utilizado com o sentido de sustentação, designando as atividades do adulto empregadas para ajudar a criança a compreender, pois para se beneficiar da tutela, precisa-se primeiramente compreender a solução, para depois então, realizá-la. Assim, Bruner ( op.cit) caracteriza as condutas do adulto nesta função de sustentação, distinguindo seis aspectos: 
1) engajamento: criar interesse e motivação para a criança para que ela realize a tarefa;

2) redução dos graus de liberdade: simplificação da tarefa em subtarefas, que estejam ao alcance da criança;

3) manutenção da orientação: manter a criança dentro do objetivo da tarefa, evitando desvio do objetivo final;

4) sinalização das características determinantes: assinalar as características da tarefa que são pertinentes para sua execução, apontar a produção adequada ou não adequada, levando-a compreender as diferenças;

5) controle da frustração: estimular o prazer de realizar a tarefa, encorajando-a mesmo quando não foi bem sucedida, para não criar dependência do adulto;

6) demonstração: apresentação de um modelo ou de uma solução estilizada para a criança, mostrando como pode ser executada e o que pode ser aceito ou não para ela retomar de outra forma;

Hausendorf (1993), François (1996), Hudelot (1996, 1997), questionam a noção bruneriana de tutela. Hausendorf (1993) refere que a metáfora da tutela pode ser implicada no desenvolvimento do discurso da criança e não somente na aquisição da linguagem. Analisando a posição de Bruner (1991), conclui que o "sistema de suporte na aquisição de linguagem" proposto por pelo autor possibilita, por analogia, um "sistema de suporte na aquisição do discurso".

A seguir, o autor ( op.cit) mostra que muitos aspectos da tutela proposta por Bruner (op.cit:288), sob o ponto de vista da aquisição lingüística em crianças pequenas, também estão presentes quando se trata de desenvolvimento das características discursivas na criança de mais idade, posicionando-se assim, contrário a Bruner (op.cit) que situa a tutela somente na fase de aquisição. Segundo o autor, os aspectos como o esforço do par competente em dirigir a atenção da criança sobre a atividade / tarefa a ser realizada limitando suas escolhas, a atuação do adulto de fornecer modelos que possam orientar a criança na realização da atividade/tarefa e o ajustamento do parceiro adulto na sua atuação em relação ao nível de desenvolvimento do parceiro também podem ser observados na interação entre adulto e criança na situação de narrativa, ou seja, em uma atividade discursiva. 
Hausendorf (op.cit) propõe que seja dada maior atenção para a compreensão das relações entre interação e desenvolvimento, enfatizando as díades interativas, privilegiando o mecanismo das obrigações da interação adulto-criança e explicitando suas relações com princípios gerais e válidos por toda a interação. Somente inserindo a tutela em um conjunto funcional, em uma rede de tipos de interação, poder-se-ia pretender explicar, sob o ponto de vista interacionista, como as estruturas interativas concretas podem produzem os efeitos observados. Visto desta maneira é que o sistema interativo pode ser concebido como realidade social que poderia aparecer a "ZDP", conceito que trata de explicar a pertinência da interação entre adulto e criança no desenvolvimento (Hausendorf, op. cit.).

\subsection{Conceito e tipos de tutela: a tutela discursiva}

François (1986) aponta que, na tutela bruneriana, a criança está em na posição de quem não sabe e o adulto na posição de quem sabe. No caso da linguagem, pode-se observar que muitas vezes a criança faz usos que o adulto nem é capaz de fazê-lo. Assim, a criança e o adulto, na situação dialógica esboçam, enquanto sujeitos discursivos, o movimento de seus discursos, os gêneros, modo de categorização, deslocamentos temáticos, enfim, o conhecimento de mundo de cada um está presente em seus respectivos discursos. E é assim que, na situação dialógica, a tutela participa como forma de interpretação.

François (1996) enfoca a tutela como o modo em que criança reage ao discurso do adulto, considerando ou não o que lhe foi dito e as intervenções do adulto. Segundo o autor (op.cit), a tutela aparece de duas formas no discurso: a tutela global que dá um sentido próprio à situação de diálogo, associado ao que o tutor representa para a criança num dado contexto situacional e; a tutela local baseada naquilo que se faz com determinados enunciados, gestos ou olhar num dado momento da interação.

O autor (op. cit.) propõe-se a estudar a tutela sob quatro pontos de vista: o momento da intervenção, as intervenções que respeitam o discurso da criança, as diversas modalidades lingüísticas da interação (complementar, sobrepor, substituir, aprovar, reformular, correção metalingüística), e os efeitos explícitos no discurso da criança. Caracteriza as modalidades em: forma paralela do modelo imitado ou da série, que François (op. cit) denomina tutela paralela estrita, quando o adulto faz o que a criança 
deve fazer, e de tutela paralela por esboço, quando o adulto começa o que a criança deve terminar; forma complementar, quando o esboço desencadeia a seqüência no outro, denominada de tutela complementar, que busca favorecer a ampliação da produção da criança e aparece nas situações questões-respostas, ordens ou proibições; e forma metalingüística, que é a tutela metalingüística, quando a criança desenvolve, modifica, resume, isto é, faz retomadas/modificações do discurso do outro. Mas, a tutela pode tornarse contra - tutela quando, ou a tarefa é muito difícil para a criança que sente a impossibilidade de solucionar a situação, ou a tarefa fácil demais, e ela não sente necessidade da ajuda do adulto. Neste caso a tutela se coloca fora da Zona de Desenvolvimento Proximal (ZPD).

Como sugere François (1996), as intervenções do adulto orientam o discurso da criança. Os enunciados apresentam uma dinâmica que cria uma sucessão de gêneros discursivos, ou seja, de micro-encadeamentos que levam a macro-encadeamentos. Assim, o autor distinguiu as seqüências discursivas em: a) seqüências de encadeamento de enunciados conduzidos de forma quase linear pelo adulto, que retoma episódios particulares; b) o adulto pede uma explicação conduzindo a um gênero não somente narrativo da criança. São as seqüências explicativas que aparecem quando se necessita em alguns momentos de mudanças (modificações) que se entrecruzam entre designação de personagens, elucidação das motivações, chamada de episódios negligentes ; c) o adulto pede para a criança reformular um enunciado anterior interrompendo a linearidade narrativa solicitando confirmação ou explicitação. Desta forma, o autor mostra que a tutela não é um fenômeno linear, mas uma rede de gêneros discursivos, narrativos, descritivos, explicativos, argumentativos.

Para Hudelot e Vasseur (1997), o termo "tutela" tornou-se um recorte no fluxo verbal interlocutivo e não num modo de funcionamento dos interlocutores, contradizendose assim à teoria que está embasado. Buscando entender os diferentes sentidos da noção de tutela, Hudelot (1996), Hudelot e Vasseur (1997) destacam os diferentes usos que o termo compreende:

- tutela como intenção eventualmente programada, ou seja, quando um tutor realiza uma intervenção segundo um protocolo pré-estabelecido para conduzir a criança na realização de uma tarefa (Bruner, 1991);

- tutela como tradução (trans)-semiótica. Ocorre quando uma atividade semiótica corporal ou verbal auxilia no desenvolvimento ou na aprendizagem de uma 
conduta. Apresenta traços de complementaridade, de contigüidade ou de continuidade. Surge quando a comunicação não verbal tutela a comunicação verbal;

- tutela como reação aos dizeres do outro. A relação social estruturada que se estabeleceu entre dois parceiros insere-se numa interação contingente no sentido em que a reação de cada um é dependente das reações anteriores do outro (definido por Bruner como formats). (Bruner op. cit.);

- tutela como busca pelo novo. Bruner (op. cit.) mostrou que os formats constituem um contexto auxiliando o parceiro mais novo. Trata-se das intervenções de um mais experiente que assume as funções de informante, de reparador e de avaliador com o intuito de cobrir as insuficiências do outro menos experiente;

- tutela como desencadeador de atividade. Pretende garantir o desenrolar da interação. A atividade desencadeada no outro é produzida na ZDP (Vygotsky, 1986), onde a tutela é atividade conjunta ao outro com o intuito de auxílio para a realização do que ele não conseguir sozinho, buscando manter a interação;

- tutela como atitude global. Neste nível as intervenções locais e explícitas exercem um papel de organizador do discurso do outro;

- tutela de tutela. Quando o menos experiente avalia a tutela oferecida pelo mais experiente. Esta avaliação aparece nos discursos produzidos em reação a ajuda oferecida, na continuidade, na retomada ou na ruptura, nos discursos que mostram se a questão foi ou não eficiente, se a palavra oferecida seria, ou não, a palavra pesquisada ou que o comentário permitiu ou não avançar o discurso;

- tutela virtual ou diálogo de si com si mesmo. Esse tipo de atividade, o locutor inexperiente verbalizando as hesitações, os questionamentos e auto-reformulações do outro tomando como modelo ou pedindo que ele represente como sendo do outro;

- tutela como um movimento dialógico entre outros. Pode-se considerar que a tutela trata de um movimento discursivo particular, composto por características nas quais possamos identificar efeitos dialógicos, em geral, e condutas linguageiras particulares.

Hudelot e Vasseur (1997) consideram que a tutela linguageira depende bastante da concepção que se faz de língua, de linguagem e de comunicação verbal. Como apontam os autores, se a linguagem for considerada unicamente como objeto formal, o procedimento considerado "tutelar" é aquele que visa esclarecer uma formulação. Se considerarmos a linguagem como circulação de sentido, e não somente expressão de sua forma, a tutela 
pode ser vista como uma conduta que, pressupondo uma ajuda pelo parceiro, fornece significação ao interlocutor em relação a certo objeto, pois é na interlocução que a conduta linguageira e a matriz lingüística se moldam.

Hudelot (1996) por sua vez, chama a atenção para as características que distinguem a tutela na situação de resolução de problemas e/ou tarefas prática e nas situações de elaboração discursiva. $\mathrm{Na}$ situação discursiva, o adulto não conheceria por antecipação o produto final. Desta forma, a tutela poderia ser inscrita em uma espécie de jogo de linguagem (ou de gênero) e, neste caso, a tarefa não é explícita, não tem um modelo a ser seguido, assim como não há uma única forma de colocar as palavras, ao contrário, têm-se diversos meios lingüísticos para expressar uma mesma significação ou relação, além de diversas estratégias discursivas possíveis para serem utilizadas para explicar um jogo ou narrar um evento.

O autor (op.cit) destaca dois aspectos importantes da posição de Bruner (1991) com respeito à tutela: o entendimento de que a compreensão deve preceder a produção, pois de fato sem a compreensão não se tem feedback real; e o reconhecimento do jogo como uma das características dominantes presentes na interação mãe e criança..Para Hudelot (op. cit.), o efeito do jogo nesta interação é de atrair a atenção da criança sobre a comunicação, num momento em que a criança estaria mais atenta a forma do que a função, facilitando assim, a condução da criança na utilização dos meios convencionais de expressar as suas intenções.

A esse propósito, Hudelot (op. cit.) reconhece que os estudos de Bruner contribuíram para modificar a perspectiva dos trabalhos sobre aquisição de linguagem, pois colaboraram para uma mudança paradigmática nas pesquisas em psicolingüística, mostrando que a criança não aprende a linguagem sozinha e inscrevendo o diálogo como contexto para a criança aprender a obter resultados comunicativos mais eficazes com o parceiro de interlocução. Além disso, mostrou um modelo transacional, no qual não se atém nem no input nem no output da criança (item 1 e 2), mas na compreensão das regras do diálogo (organização das estruturas preposicionais, princípio da dêixis pelos qual, o contexto interlocutivo pode estar estabelecido), na troca e no modo como as intervenções podem estar assinaladas ou interpretadas.

Para Hudelot (1997), inscrever a tutela na interlocução desde o início da aquisição, implica em compartilhar das propriedades da linguagem. 
* Multiplicidade das semióticas verbais: a linguagem se caracteriza pela diversidade dos modos de significar. Essa diversidade aparece nos atos ou jogos de linguagem (no uso da linguagem para pedir, chamar, evocar, rever) de acordo com as condições de interlocução. Conforme enfatiza François (1996: 135), se não apreendemos o sentido, nós o interpretamos. Entende-se, assim, que tutelar pode ser uma maneira de significar, uma maneira de interpretar. $\mathrm{O}$ contexto discursivo serve às vezes de quadro e às vezes de base à tutela. Permite o partilhar de intenções, das referências deiêiticas comuns, de estabelecer e controlar as pressuposições criadas nas condições de tutela.

* A relação de sentido na atividade linguageira não é uma relação biunívoca código-mensagem, mas uma relação entre o que se diz e a maneira que o outro retoma ou modifica o que foi dito.A tutela se inscreve,portanto, naquela relação, seja retomando, ou seja modificando o que vem a ser dito pelo outro, sem prejudicar as reações ou efeitos desencadeados.

* Inscreve-se também na redundância e nas rotinas: as atividades linguageiras comportam rotinas. Ensinar para o inexperiente consiste em decompor uma tarefa em constituintes mais ou menos rotineiros para recombiná-los depois. Esse aspecto da tutela se refere à simplificação, o caráter parafrásico do discurso, as redundâncias, as repetições, as retomadas, as reformulações, e etc...

* A relação dialógica constitui-se de uma relação com o outro e uma relação com si mesmo e, ao mesmo tempo, uma relação com os dizeres do outro e uma relação com seus próprios dizeres: essa relação permite o desenvolvimento de atividade reflexiva (VasseurArdity,1997, apud Hudelot, 1997:113). A tutela pode aparecer como um comentário (implícito ou explícito), uma paráfrase, uma tradução interna ou externa do discurso do outro. O experiente mais que o inexperiente age com conhecimento de causa e pode favorecer o surgimento de uma tomada de consciência, súbita ou progressiva que permite a elaboração e a apropriação de significados.

* A tutela situa-se na dimensão dinâmica da linguagem na medida em que as retomadas-modificações realizadas nos discursos do outro são retomadas-modificações de seu próprio discurso. O que caracteriza as trocas entre experiente- inexperiente são as 
retomadas, os retornos posteriores, as seqüências explicativas, os esclarecimentos etc., que têm o intuito de progredir a interação, garantir a troca, favorecer a construção de sentido e do desenvolvimento em geral.

Hudelot (op. cit) trata, portanto, a tutela como um movimento discursivo dinâmico, reflexivo, linguageiro, implicado na interlocução como forma de interpretar e favorecer a partilha de significação ou de intenções e negociações de proposições, a fim de promover e fazer progredir a interação. Neste espaço discursivo é que pretendemos identificar as condutas explicativas na criança.

Em seus estudos sobre a tutela na brincadeira de ficção, Verba (1999) considera a interação de tutela, nos jogos simbólicos, pela atividade mental que caracteriza a brincadeira e pela dinâmica das trocas sociais que dão sentido à atividade.

Assim, analisando o encadeamento das produções simbólicas do adulto e da criança e, os diferentes modos de construção e partilha de significações simbólicas no jogo de ficção, Verba (1999) delimitou algumas modalidades de tutela, considerando desde a gestão relativamente autônoma da criança no jogo até à gestão exclusiva do adulto. Diante desta abordagem, analisamos a dinâmica discursiva proposta por Hudelot ( op. cit), como veremos a seguir.

\subsection{As dinâmicas sociais e cognitivas e a posição discursiva do adulto na ficção.}

Como citamos, Verba (1999) delimita a tutela, no jogo de ficção, a partir da atividade mental presente e pela dinâmica das trocas sociais que dão sentido à atividade. Assim, a autora (op.cit) preocupa-se em descrever os diferentes processos sociais e cognitivos praticados nos jogos de ficção partilhados levando em conta as ligações entre as seqüências tripartites, criança -adulto- criança, que dão conta da transformação da atividade cognitiva.

Apoiada na perspectiva sócio-cognitivista, Verba (op. cit) analisa as dinâmicas interativas avaliando os encadeamentos das produções simbólicas entre adulto e criança que estão implicados aos diferentes modos de construção e partilha de significação simbólica nos jogos de ficção. Ao privilegiar as condutas comunicacionais do adulto que 
promovem e mantêm a atividade simbólica das crianças como a modalização, a solicitação, a atribuição de significados aos dizeres e fazeres da criança, a facilitação da tarefa e, estabelece algumas modalidades de tutela, considerando desde a gestão relativamente autônoma da criança na brincadeira até á contribuição unidirecional do adulto:

a) sustentação da atividade: a criança faz as construções simbólicas , coordena as idéias e o adulto participa retomando a atividade.

b) co-elaboração: as contribuições do adulto e da criança são equivalentes e as significações são partilhadas ativamente e, ás vezes, negociadas.

c) direção-participação: o adulto propõe as idéias, controla e induz a criança na atividade.

d) direção estrita: constitui como forma de modalização da representação , o adulto propõe, atua e coordena as idéias de faz-de-conta. Criança participa como espectadora.

Como podemos perceber, as modalidades de tutela apresentadas por Verba, (1990) possibilitam analisar a conduta do adulto frente á criança na atividade de ficção. Podemos constatar que as modalidades apontadas pela autora ( op. cit) mostram, na dinâmica interativa, condutas do adulto e condutas da criança em relação á atividade simbólica. Desta forma, complementando esta noção, analisamos a posição discursiva do adulto nesta dinâmica interativa. Hudelot (1996) refere que a atividade do adulto em sua função de sustentar o discurso infantil, favorece a memória, a cognição, os aspectos afetivos e relacionais da interação. Reativando, explícita ou implicitamente, a memória da criança, o adulto auxilia-a a organizar seu discurso, mantendo uma boa relação interpessoal ao mesmo tempo em que exige uma resposta um pouco melhor.

Hudelot (1997) chama de desencadeadores os enunciados da criança que provocam a intervenção do adulto. Nesta perspectiva, não se considera o discurso da criança isoladamente e nem somente as atividades do adulto, mas uma tripla relação: conduta da criança - reação contingente do adulto - reação da criança. Desta forma, as intervenções, tanto da criança quanto do adulto, tomam sentido no contexto de modo a ultrapassar as intervenções locais.

Estas intervenções, como expõem Hudelot (op. cit) podem ser iniciativas, responsivas, reativas ou aditivas. Podem ser assimétricas, complementares ou metadiscursivas.Assim podemos ter: 
* Formulação pouco compreensível - demanda de reformulação -reformulação:

A criança faz uma formulação pouco compreensível, estabelece relações discursivas sem contextualizar ao adulto que então, solicita uma reformulação .

* Mensagem atenta - reprise da colocação de palavras - aceitação ou concordância:

O adulto repete o turno da criança mostrando atenção e concordância.

* Designação por um dêitico - pedido de denominação

O adulto solicita uma denominação da criança a partir da designação apontada pela criança ( ex: o que é.... ).

* Denominação ambígua - pedido de especificação:

A criança denomina um objeto, personagem ou ação e o adulto pede que especifique melhor .

* Denominação - pedido de descrição:

A criança denomina um objeto, personagem ou ação e o adulto solicita que descreva.

*Qualificação - pedido de justificação.

A criança designa, qualifica objeto, ação ou personagem e o adulto solicita que justifique.

Entre os desencadeadores de tutela do adulto, Hudelot (1997) ressalta o silêncio das crianças. Da observação geral dos dados coletados até então, percebemos que o silêncio, em certos momentos, indica a reflexão da criança em relação à tarefa a executar, e em outros, a sua não aceitação da proposição do adulto. O silêncio dos adultos também pode ser visto como desencadeadores, como por exemplo, ao indicar aceitação dos dizeres e 
fazeres das crianças. Vale destacar que, a noção de desencadeador surge como um elemento importante na compreensão de que as propostas do adulto não são independentes Hudelot (1996) distingue a posição do adulto na interlocução avaliando: o fato que o enunciado encadeia sobre si ou sobre o outro; a resposta suscitada do alocutor, a implicação direta pelo enunciado precedente e a avaliação de um enunciado implicando num encadeamento. Assim, os enunciados dos adultos podem assumir quatro posições no diálogo de acordo com seus interlocutores:

Posição $O$ - o discurso do adulto está orientado na direção da tarefa, é independente da criança. Segundo Melo (1998), é o lugar do enquadramento da tarefa ou da introdução de um tema novo.

Posição 1 - atenção ou antecipação - o adulto ocupa um lugar antecipativo (preventivo). O adulto é pró-ativo. Predomina os enunciados interrogativos.

Posição 2 - o adulto retoma a fala da criança, esboça uma resposta e propõe seus próprios códigos, explicitando a resposta da criança.

Posição 3 - posição em que aparecem as avaliações positivas ou negativas, as reformulações parafrásicas, retomadas dubitativas, as solicitações de elucidação ou de confirmação, as solicitações de especificação.

A tutela é vista como um movimento discursivo, dinâmico, reflexivo, linguageiro. No contexto do jogo de ficção, a tutela está implicada na interlocução como forma de interpretar e favorecer a partilha de significação ou de intenções e negociações de proposições, elementos fundamentais para que o jogo possa se desenvolver. Como podemos observar, tanto Hudelot (1997) quanto Verba (1999) concordam que as condutas tutelares se apresentam em seqüências interativas em que, uma conduta da criança (simbólica, ou linguageira) desencadeia a próxima conduta do adulto. Complementamos a análise proposta por Verba (1990) avaliando a posição discursiva do adulto, proposta por Hudelot (1997) abordando assim os aspectos discursivos no jogo de ficção.

É neste espaço discursivo que identificamos as condutas explicativas na criança. 


CAPÍTULO 4
MATERIAL E MÉTODO

\subsection{A escolha dos sujeitos e do material}

Este trabalho se desenvolveu a partir de pesquisa de corte transversal realizada com seis crianças brasileiras, na faixa de idade entre cinco a seis anos, de ambos o sexo e cursando a pré-escola. As crianças foram expostas, exclusivamente, ao Português como língua materna, durante o período de coleta de dados.

Os sujeitos foram selecionados a partir dos seguintes critérios:

* Inexistência de comprometimento e/ou distúrbios de linguagem

* Autorização prévia dos pais

O importante para a pesquisa era a idade, entre cinco e seis anos de idade, faixa etária que, como já citamos anteriormente, a criança está mais capacitada a atuar em jogos de faz de conta, podendo criar temas e enredos diversos. Como ressalta Gardner (1994) na idade de cinco anos a criança é capaz de usar, de forma habilidosa, diversas formas simbólicas e ter envolvimento intenso ou extensivo em atividades cognitivas variadas. É uma mente que ainda não adquiriu a complexidade cultural e social, visto nos estereótipos, códigos morais e preferências estéticas, portanto é genuína na sua criatividade e imaginação, simples e seletiva em suas intenções. Partindo desta compreensão, decidimos por esta faixa etária.

Nosso intuito é analisar os movimentos discursivos na produção de condutas explicativas e justificativas, portanto, trata-se de um estudo descritivo e interpretativo. Apesar de optarmos por três meninas e três meninos, de níveis socioeconômicos- cultural heterogêneos, os fatores sexo e nível socioeconômico e cultural não constituíram preocupação central, visto que não é nosso objetivo analisar as influências destes fatores, embora estes pudessem refletir em nossas produções.

Optamos por utilizar na pesquisa, o jogo "Lego" * infantil e escolhemos o kit "Lego" composto por blocos médios, com quatro pares de rodas que se encaixam nos blocos, assim como dois bonecos que representam os personagens do "Sítio do Pica-Pau 
Amarelo": Emília e Visconde. Este brinquedo foi escolhido justamente por apresentar as características de um jogo de construção que possibilita sua utilização como um jogo dramático. (Coscione, 1988). É um brinquedo que envolve uma conduta estruturada com regras, característicos dos jogos de ficção e que propicia a negociação de sentidos e partilhar de significados, aspectos que a pesquisa pretende abordar. Os personagens do Sitio do Pica-Pau Amarelo foram escolhidos por considerarmos ser um facilitador para a criança criar situações de faz de conta.

Somente uma criança não conhecia bem o material de montar da "Lego" e foi necessário criar um momento para a exploração, experimentação e inclusive um aprendizado com o manuseio das peças. Esta questão não interferiu na relação com o pesquisador, nem mesmo na impossibilidade de manter a criança na pesquisa. As demais crianças já conheciam o material de montar da "Lego", não sendo, portanto, necessário um período para aprendizagem de sua utilização.

\subsection{Procedimentos adotados na coleta de dados}

As seis crianças foram observadas em duas sessões de 20 a 30 minutos cada (de acordo com o interesse da criança pela atividade), realizadas em dias diferentes. Determinamos este tempo para a duração das gravações pela necessidade de evitar cansaço por parte da criança, permitindo maior flexibilidade quanto à realização deste, evitando ansiedade ou falta de motivação. A preocupação foi de criar um ambiente prazeroso, que estimulasse a criança a participar e atenuar os possíveis constrangimentos que pudessem surgir numa relação dialógica, em que as crianças sabiam que estavam sendo "observadas".

A situação lúdica criada para a pesquisa era semi-dirigida, propiciando uma dificuldade pequena. Os blocos eram colocados frente à criança e, então, solicitada que brincasse livremente.

* Esse jogo foi criado pela empresa LEGO, que hoje se chama LEGO Educacional Division e tem como base a filosofia de que a criança pode construir seu próprio conhecimento, utilizando-se de recursos tecnológicos, guiando-se pelo método do construtivismo, ou seja, aprender fazendo. Os blocos "Lego" são brinquedos de montar, cujo objetivo principal é estimular a imaginação e a criatividade da criança, encorajar a descobrir, experimentar e expressar seu próprio mundo. Compõe-se de blocos de material plástico, de diversos formatos, cores e tamanhos, que se encaixam entre si. São produzidos de acordo com cada faixa etária específica e conforme desenvolvimento e progressão e educacional.(informações retiradas do site " www.edacom.com.br"). 
O adulto interferia o menos possível e deveria interagir conforme a solicitação da criança ou da situação.

As sessões foram gravadas em vídeo (VHS) e transcritas integralmente e minuciosamente. A opção pelas filmagens se justifica pela necessidade de um registro de comunicação não verbal (gestos, olhares...), imprescindível para o registro da intenção e comunicação não-verbal, baseado na verbalização ou expressão corporal. Este registro se faz necessário já que entendemos que muitas condutas explicativas/justificativas recaem sobre estados internos, sobre as intenções ou avaliação da criança na situação ou na ação, casos em que o explanandum pode aparecer implícito, solicitado por uma intenção ou comunicação não verbal.

Uma vez que nos interessa observar a intenção da criança manifestada pela direção do olhar, ações, condutas comunicativas verbais e não verbais das crianças e expressões emocionais, optamos por transcrever os diálogos com base ás normas do Projeto NURCUSP (Projeto de Estudo da Norma Lingüística Urbana Culta de São Paulo, Preti e Urbano, 1990). Cada criança será identificada pela letra inicial de seus nomes ( $G, J, L, N, J P$ e B respectivamente) e o adulto-pesquisador por A. Os turnos das crianças serão registrados em itálico, diferenciando-os dos turnos do adulto.

\subsection{As categorias de análise}

Com base no quadro teórico apresentado e no exame dos corpora, observamos:

1) a organização interindividual dos jogos de ficção e o papel das condutas explicativas/justificativas nesta organização;

2) a necessidade de partilhar significados: identificar, nas situações interativas entre adulto-criança, as condutas explicativas e justificativas que se reportam aos processos de partilha e negociação de sentidos;

3) correlacionar a posição do adulto , segundo Hudelot (1987) e as interações de tutela no jogo de ficção, segundo Verba (1999) ás condutas explicativas/justicativas presentes no jogo de fíç̧ão. 
Elegemos os seguintes autores para nortearem a análise dos dados: no que diz respeito aos aspectos discursivos da conduta do diálogo, nos apoiaremos em François (1996), Hudelot (1996, 1997), Melo (1998 a e b); Verba (1990,1999) norteará a análise dos aspectos do jogo e da partilha de significação; Mollo e Belleval-Berthoux (1990), Veneziano, Favre e Papandrolou (1990), Hudelot (1997), Hudelot e Veneziano (2002), nos ajudarão na definição de explicação, e Fávero (2002), Koch (2002, 2003) e Chalhub (2002), entre outros, contribuem para o estudo da coesão, coerência e da metalinguagem, respectivamente, observadas nas produções das crianças.

Para a análise estabelecemos os seguintes critérios:

a) selecionamos os episódios de faz-de-conta que se desenvolveram ao redor de um tema geral. (ex. passeio de carro, comer etc.) e em cada episódio identificamos seqüênciaschaves de acordo com sua articulação no jogo (constituição do cenário; construção de objetos, personagens; encadeamento de eventos e idéias e etc);

b) em cada seqüência-chave, identificamos as condutas explicativas/ justificativas e avaliamos as características discursivas;

c) correlacionamos ás condutas explicativas/ justificativas, as condutas tutelares e a posição do adulto.

Assim, para as condutas tutelares, nos apoiamos nas modalidades indicadas por Verba (1990):

\begin{tabular}{|c|l|}
\hline sustentação da atividade da criança & $\begin{array}{l}\text { Criança constrói o jogo. O adulto não } \\
\text { introduz idéias novas, somente aceita as } \\
\text { proposições, confirmando e interpretando. }\end{array}$ \\
\hline co-elaboração & $\begin{array}{l}\text { Ambos, adulto e criança têm um papel } \\
\text { construtivo na gestão do jogo, apresentando } \\
\text { idéias, realizando as construções simbólicas } \\
\text { e coordenando-as. }\end{array}$ \\
\hline
\end{tabular}




\begin{tabular}{|c|c|}
\hline direção-participação & $\begin{array}{l}\text { Adulto dirige a criança propondo ou } \\
\text { modalizado uma idéia, explicando e/ou } \\
\text { facilitando a atividade. O jogo é proposto } \\
\text { pelo adulto e a criança se apropria das } \\
\text { significações, corresponde ás solicitações } \\
\text { do adulto. }\end{array}$ \\
\hline direção-estrita & $\begin{array}{l}\text { Adulto propõe e coordena as construções } \\
\text { simbólicas e as idéias sem considerar, em } \\
\text { particular, a participação da criança. Para o } \\
\text { adulto o que importa é a sucessão de } \\
\text { eventos e sua coerência e não a participação } \\
\text { ativa da criança, sua atuação é mais } \\
\text { individual, como se correspondesse á } \\
\text { representação de um script ou de seqüência } \\
\text { de ações de faz-de-conta como num } \\
\text { espetáculo. A criança manifesta seu } \\
\text { interesse sem atuação, se mantém como } \\
\text { observadora. }\end{array}$ \\
\hline negociação do tema & $\begin{array}{l}\text { A criança manifesta seu desacordo em } \\
\text { relação à proposição ou significação dada } \\
\text { pelo adulto que tenta compreender sua } \\
\text { intenção e se ajustar, buscar um acordo. }\end{array}$ \\
\hline Outros & $\begin{array}{l}\text { São as dinâmicas atípicas ou que não se } \\
\text { classificam facilmente como as atividades } \\
\text { intermediárias entre as atividades } \\
\text { exploratórias e as simbólicas. }\end{array}$ \\
\hline
\end{tabular}

Com relação á posição do adulto apresentada por Hudelot , (1997) temos:

\begin{tabular}{|c|c|c|c|}
\hline Posição 0 & Posição 1 & Posição 2 & Posição 3 \\
$\begin{array}{c}\text { Adulto } \\
\text { direciona a tarefa, sem } \\
\text { leva em conta a fala da } \\
\text { criança }\end{array}$ & $\begin{array}{l}\text { Adulto pro- } \\
\text { ativo, antecipativo, } \\
\text { solicita a fala da } \\
\text { criança }\end{array}$ & $\begin{array}{c}\text { Adulto } \\
\text { responde no lugar } \\
\text { da criança, } \\
\text { apresenta sua } \\
\text { própria codificação }\end{array}$ & $\begin{array}{c}\text { Adulto } \\
\text { avalia a fala da } \\
\text { criança, aparece as } \\
\text { reformulações } \\
\text { parafrásicas, } \\
\text { pedido de } \\
\text { confirmação e } \\
\text { da tarefa }\end{array}$ \\
\hline
\end{tabular}

A partir destas colocações, discutiremos as condutas explicativas/ justificativas e suas relações com as condutas tutelares encontradas nos corpora. 


\section{CAPÍTULO 5}

ANÁLISE E INTERPRETAÇÃO DOS RESULTADOS

Ao analisarmos os corpora, observamos que a subjetividade, expressividade e a intuição são bastante freqüentes no discurso da criança. As seqüências explicativas que a criança produz em seu discurso apresentam mais respostas subjetivas e seguem mais a intuição que a lógica. Em nosso corpora identificamos 359 condutas explicativas/justificativas produzidas no jogo de ficção.

Com base na distinção apresentada por Verba (1990) com relação às diferentes formas de jogar, examinamos três formas nos corpora . Uma forma se refere às atividades de construção simbólica, na qual a criança constrói objetos, animais, lugares, personagens com os blocos "Lego", nomeando-os ou assinalando alguma função e/ou característica particular.A segunda forma se refere aos jogos de ficção propriamente ditos, parafraseando Verba (1990). São as atividades, em que a criança articula suas idéias e os elementos construídos com os blocos, numa seqüência de eventos encadeados no tempo e espaço. Nestes jogos há cenários, papéis são representados, há encadeamento de ações e eventos conforme um tema ou roteiro. Na terceira forma encontrada, o jogo "Lego" serviu de suporte para outra brincadeira, como acontece no jogo de adivinhação realizado por uma das crianças.

Em nosso trabalho, manteremos a distinção apresentada por Verba (1990), porém utilizaremos uma denominação diferente para jogos de ficção propriamente dito, pois julgamos mais apropriado idéias e encadeamento de eventos. Segundo Gardner (2002:62), o "uso de roteiros" pela criança no jogo de faz-de-conta envolve a identificação e ordenamento de elementos (figuras), que estão associados a um evento recorrente. O autor (op. cit:62) descreve que " os roteiros servem como conjuntos genéricos de seqüências de eventos contra quais eventos recentemente encontrados são julgados". Assim, tomando como base esta noção e considerando que a diferença entre a forma de construção simbólica e a de jogo de ficção propriamente dito é que, a primeira se refere à construção de elementos, e a segunda, às idéias e aos encadeamentos realizados a partir dos elementos construídos, manteremos o termo construção simbólica, e optamos por utilizar idéias e 
encadeamento de eventos, em substituição ao termo "jogo de ficção propriamente dito" utilizado por Verba (1990).

A partir disto, observamos que os episódios de construção simbólica encontrados se constituíam de: a) construção simples, em que a criança manipula os blocos para a construção de um objeto; b) construções simbólicas associadas a uma ação de faz-de-conta, que são os a criança aplica uma ação de faz-de-conta ao objeto construído ( por exemplo, fazendo um carrinho e empurrando pelo chão, como se estivesse em movimento); e c) as construções simbólicas para construção de cenário, (Verba, 1990). Cada episódio está delimitado por um tema. Quando a criança construiu uma mesa para o cenário, delimitamos o tema mesa. Quando a criança construiu o trem e aplicou uma ação de andar pelo chão com o trem, delimitamos o tema trem. Quando montou o carro, tema carro. Em nossos corpora, percebemos que, muitas vezes, as crianças montavam e desmontavam objetos ou outros elementos por prazer. A ação de faz-de-conta, nos episódios de construções simbólicas, surgia para enfatizar a categorização do objeto ou personagem construído. As construções simbólicas em cenário apareciam geralmente antes, mas também durante os episódios de encadeamento de eventos e idéias.

Koch (2003) salienta que, na conversação, os parceiros na interação têm atenção centrada em um ou vários assuntos, que são delimitados, denominados na literatura de "tópicos". Esses temas, que identificamos nos jogos, podem ser relacionados aos tópicos discursivos e aos subtópicos na medida em que integram o tema e serão articulados na interação. Muitas vezes, percebemos que a criança "joga ao acaso" ou "desloca" proposições que parecem estar desarticuladas. Ainda retomando a autora (op. cit), isto se deve à natureza interacional da interação face a face (ou conversação), que é planejada localmente, ou replanejada no jogo a cada "lance" ou proposição, pela característica de descontinuidade freqüênte devida a fatores de ordem cognitivo-interativa, que solicitam justificativas pragmáticas, sinalizando a importância das condutas explicativas/justificativas no jogo de faz-de-conta.

Segundo Mollo e B-Berthoux (1999), as seqüências explicativas que surgem na situação criança - adulto em situação de jogo podem aparecer como motivação do agir e como explicação propriamente dita. As condutas explicativas/justificativas apareceram para explicar e possibilitar a gestão do jogo e/ou para responder a um "porque" do adulto. Ás vezes o adulto induz um comportamento dialógico particular, visando produzir uma 
explicação que geralmente, se relaciona com a gestão dos saberes ou visa explicitar, dar suporte à informação e criar intervenções para a gestão de ações. Exemplos:

* Os comentários - gestão dos afetos - motivação para o agir

1) A - você está tendo uma idéia?

2) N - ((silêncio)) ((pega as peças do " lego" e monta alguma coisa))

((ao terminar mostra o que montou, olha para A ))

3) A - ((silêncio, observa)) Ah

4) $\mathrm{N}$ - é um carrinho

5) A - um carrinho para Ele \{ e outro para ela ((aponta ))

6) $\mathrm{N}$ - $\quad$ \{ e outro para ela (( mostra o que ela fez))

* As regulações - gestão do jogo

58)- A: este ... será que agora dá?

59)- N: dá (( tenta encaixar uma peça e não consegue))

60)- A: põe aSSIM ...VAmos ver ((observa))

61)- N: (( movimenta o carrinho passando por baixo do bloco encaixado)) $D A$

62)- A: DEu?

63)- N: só não passa o chapeuZInho um pouquinho

64)- A: ah... passa BEm raspando

65)- N: agora os carros não passam ...SÓ eles...tititi (( onomatopéia do movimento do boneco andando e pelo chão))

* As explicações - gestão dos saberes

((criança e adulto montam uma porteira para um sítio fictício, e dois bonecos encaixados num carro deveriam passar pela porteira)). 
1)- A: vou por o telhado assim... será que eles passam? ...vamos ver...

2) - N: de carro não deve passar... \{a pé

3) - A: $\quad$ a pé deve, de carro não

4 ) -N: ((N tenta passar o carro por debaixo da peça que montaram))

5) - A: passou ou não passou?

6)- $\mathrm{N}$ : não ....não porque eles estão muito alto

As crianças dos corpora construíram episódios maiores ou menores na brincadeira com o jogo "Lego". Podemos observar que as diferentes formas de jogar podem aparecer isoladas ou interligadas. Na organização dos jogos, a criança pode primeiro construir elementos para, depois, introduzí-los em eventos, no tempo e espaço.

A seguir discutiremos alguns exemplos de episódios de construção simbólica correlacionando as posições no diálogo de Hudelot (1987), as modalidades de tutela segundo Verba (1990) e as condutas explicativas/justificativas de acordo com Veneziano e Hudelot, (2002), e Veneziano et all (2003), destacando seus aspectos discursivos e comunicacionais.

A) Condutas explicativas/justificativas nos episódios de construção simbólica

Selecionamos dentre os vários episódios de construção simbólica que apareceram nos corpora, alguns exemplos:

Exemplo 1: [a criança montou um cortador de grama e empurra a peça pelo chão que desmonta.Ela, refaz a montagem e A observa.]

119-A: ((observa))

120-N: aÍ.....só falta uma coisa ........ espera um pouco ((pega o cortador e encaixa mais uma vez com mais firmeza fazendo expressão de esforço))

121-A: ahn? que qui tá faltando? 
122-N: Isso ((acrescenta mais blocos ao cortador de grama, fazendo expressão de esforço e descaracterizando a montagem anterior ))

123-A: que qui é isso?

124-N: um RAto

125-A: que qui é ISso...rato tem roda?

126-N: não ...isso é a PERna dele NÉ

127-A: mas ele

128-N: \{senão ele não ANda

129-A: certo... mas o rato tem rabo....cadê o rabo?

130-N: não dá para fazer

131-A: ah ...então ele vai ficar sem rabo?

132-N: wh...rabo dele tinha cortado...tava quase mortinho

133-A: coitado... ah....... ah... ((fazendo expressão de dó))

\section{Comentários}

No exemplo anterior, a criança introduz sua proposição , no turno (120), aÍ.....só falta uma coisa ....... espera um pouco. Neste momento, o adulto interage perguntando ahn? que qui tá faltando?, turno (121) e realiza uma tutela complementar que segundo François (1996) se trata de quando o adulto estimula a criança na continuidade da tarefa, como podemos atestar pela resposta da criança no turno (122), Isso, como se fosse: porque falta isso, explicando para o adulto sua ação.

No turno (125) que qui é ISso...rato tem roda? , a conduta tutelar do adulto de sustentar a atividade da criança desencadeou sua conduta explicativa/justificativa (turno 126) não ...isso é a PERna dele NÉ. Buscando partilhar sua significação dada à montagem com os blocos "Lego", ela fornece uma justificativa, turno (128) senão ele não ANda, que indica a intenção da criança em negociar o sentido dado e criado no imaginário. Segundo Castro (1996: 213), “o enunciado com $x$ senão $y$ é um procedimento que pode ser usado como justificativa de regras do mundo físico ou social, ou como justificativa da própria ação ou até como ação sobre o objeto lingüístico". Percebemos que a conduta tutelar e a conduta explicativa, ocorrem para estabelecer um quadro comum de significações, promovendo um acordo entre os parceiros importante para a gestão do jogo. A posição do adulto no diálogo, segundo Hudelot (1997) é a posição 1, que prevalece nos enunciados 
interrogativos. A conduta tutelar do adulto desencadeou a explicação da criança do turno (126), Isso é a perna dele , ou seja , é o explanans do turno (125) e para turno (128) é seu explanandum . O explanans, tanto do turno (126) quanto do turno (128), recaiu sobre a intenção da criança e a conduta explicativa/justificativa forneceu dados sobre as características do objeto, (Veneziano, 2003).

Nos turnos (129) (133), notamos que o adulto atribui características na descrição do animal rato. Ao realizar a conduta explicativa/justificativa nos turnos (130) não dá para fazer, ela explica sobre sua incapacidade de desempenhar a montagem solicitada. Em (132): unh...rabo dele tinha cortado...tava quase mortinho, ela confirma a caracterização do animal rato, com uma justificativa com porque implícito ( elidido). A intenção é justificar o uso de porque ela vai deixar o rato sem rabo. É como se dissesse: não dá para fazer o rabo, então, faz-de-conta que o rabo dele estava cortado porque estava quase mortinho. O explanandum aqui é sua incapacidade de realizar a ação. Ela lança uma argumento para se justificar, e ao mesmo tempo, explica e justifica sua nova proposição.

A conduta tutelar do adulto no turno (129) certo... mas o rato tem rabo....cadê o rabo?, tem como objetivo dirigir a atividade da criança, na medida em que lhe propõe uma caracterização diferente, e leva a criança a buscar uma negociação com o adulto, em relação aos significados dados por ela na caracterização do objeto, indicando a modalidade de tutela negociação do tema, (Verba, 1990). O adulto assume então a posição 2 , no diálogo, (Hudelot , 1987), com a criança em ambos turnos (129) e (131) desencadeando a negociação, na qual a crianca apresenta uma justificativa ao pedido implícito do adulto ao porque ele ficou sem rabo.

Assim, dos desencadeadores de tutela segundo Hudelot ( 1987), que podemos observar temos: denominação e pedido de descrição, turnos (120), (121) e turno (123); designação por um dêitico e pedido de denomiação, turnos (122), (123) e (124); denominação ambígua e pedido de especificação nos turnos (125), (126),(128) ; qualificação-pedido de justificação em (132) e (133).

Exemplo 2:[ A criança (L) faz encaixes tentando descobrir as peças mais adequadas à sua montagem, termina e mostra para (A).]

172-L: ( ) televisão 
173-A: essa é uma televisão? como que é isso?

174--L: televisão de raio

175-A: de raio?.. que qui é isso?

176-L: já viu raio?

177-A: já

178-L: então é uma televisão de raio....aí...no buraco

179-A: e como é televisão de raio ...eu nunca vi televisão de raio

180-L: é de outro país essa televisão

181-A: ah:::: de outro país essa televisão

182-L: é ... é :..... lá... e tem que ficar mu:.:ito longe dela ...senão.:.

183-A: e como funciona essa televisão?

184-L: de raio ... com raio

185-A: então... com que eu ligo?... e se cai um raio?

186-L: cai o raio aqui óh (( mostra o lugar))

187-A: e aí ela só liga quando tem raio?

188-L: é...é

189-A: e quando não tem raio... a televisão não liga?

190-L: só:.....se.:..: colocar água ..ela liga.

191-A:ah tá/... porque senão o dia que não tem raio \{ela não vai ligar

192-L:

\{água quente

193-A: ah ..tem que ser água quente?

194-L: é água quente

195-A: e porque tem que ser água quente?

196-L: uh... ...uma coisa eu não... nunca vi essa televisão um dia... mas eu .... só vi na minha televisão

197-A: você viu essa televisão na televisão?

198-L: é mas eu não entendi .... que ela é dos chineses.....

199-A: ah.... ela é dos chineses... tá/ certo... eu nunca vi essa televisão e nem na televisão

200-L: é ... e tem essa CApa para proteger... quando tá chovendo água fria então tem que co.....apertál aqui e aí a capa .... perail/ (( encaixa um novo bloco))

201-A: o que acontece com a capa? 
202-L: espera ... tô/ montando aqui ((encaixa a capa))....aí a capa tá aqui ... aperta o botão e ela se levanta e vai aqui ((aponta))

203-A: aí ela cobre

204- L: $\dot{e}$

205-A: isso se chover água FRIa?

206-L: é

207-A: e se chover Água QUENte?

208-L: (( silêncio pensativo))

209-A: aí ela fica lá embaixo? (( aponta abaixo da televisão))

210-L: é

211-A: mas você já viu chover água quente?...eu só vi chover água FRIa

212-L : ((olha para A)) ..não.. mas é de outro paÍS... eu já falei que essa televisão é de outro paÍS... eu não falei?

213-A: é dos chine:::ses é verdade ....é dos chineses... você falou... é verdade

\section{Comentários}

Neste episódio, o adulto atua, segundo a modalidade sustentação da atividade da criança, (Verba, 1999). A princípio, o adulto acredita que a criança está inventando um tipo de televisão. $\mathrm{Na}$ e pela interação, e a partir das condutas explicativas/ justificativas da criança, é que o adulto percebe tratar-se de um objeto que a criança viu em algum programa de televisão. O fragmento acima destaca várias condutas explicativas/justificativas produzidas pela criança, solicitadas pelo adulto, desde os turnos (173) até (205). Observamos as seguintes posições do adulto no diálogo, conforme propõe Hudelot (1987), desencadeadoras de explicações/justificações: posição 1, presente nos turnos (173), (175), (183), (185), (189), (195) e (201), posição que leva o adulto a envolver a criança numa questão a ser resolvida; posição 2 , nos turnos (191) e (199), posição em que o adulto retoma e explicita a resposta da criança; e posição 3 , nos turnos (179), (181), (187), (193), (197), quando o adulto retoma a fala da criança solicitando-lhe especificações, confirmações, ao mesmo tempo em que avalia sua resposta. Em todas estas posições o adulto manteve uma conduta tutelar de sustentação da atividade da criança, (Verba, 1999).

No turno (211), verificamos a ocorrência de uma tutela insistente ( Bitar, 2002) pois adulto realiza várias intervenções como vemos no turno (205) isso se chover água 
FRIa?, até o turno (211) mas você já viu chover água quente?...eu só vi chover água FRIa, que desencadeia então a conduta explicativa/justificativa na criança (212) não.. mas é de outro paÍS... eu já falei que essa televisão é de outro paÍS... eu não falei?. Para (L) estava difícil resolver a questão colocada por (A), em relação à água quente e à água fria. $\mathrm{Na}$ verdade, ele já havia pontuado argumentos sobre a questão, em turnos anteriores, explicando que não conhecia bem o objeto, (turno 196) e com a conduta explicativa / justificativa, ele, ao mesmo tempo em que toma uma posiciona frente à questão ( eu não sei sobre isto), explica para o adulto que desconhece a resposta e justifica sua posição.

As explicações/justificações dadas referem-se às características do objeto televisão. (turnos 174, 178, 180, 182, 184, 186, 190, 192, 194, 198, 200 e 202). Quatro explicações /justificações produzidas consistem em avaliações da criança quanto à situação, (Veneziano, 2003). Podemos observar que, em três situações, a criança utiliza o operador mas. Koch (2002:73), retomando a literatura, ressalta que "o operador mas pode exprimir um movimento psicológico entre crenças, opiniões, emoções, desejos, ainda que implícitos, quando orientados em sentidos contrários". É o que notamos nos turnos (196) (...) ... mas eu .... só vi na minha televisão, (198) é mas eu não entendi ...(...), e (212) não...mas é de outro paÍS... eu já falei que essa televisão é de outro paÍS... eu não falei?, a criança utiliza este operador mas, para traduzir o movimento de ver e não ver, entender e não entender, presentes nos dois primeiros turnos, e ser e não ser e de falar e não falar, presentes no turno (212), com o mas elidido na segunda pausa deste turno.

Como podemos notar, explanans e explanadum aparecem juntos, nestes turnos. Em (196) uhn... ...uma coisa eu não... nunca vi essa televisão um dia... mas eu .... só vi na minha televisão, observamos que a criança explica que não sabe ( forma elidida) e justifica esse não saber, logo em seguida.A interpretação que podemos fazer: eu não sei... porque eu nunca vi esta televisão no real ....porque somente assisti sua imagem na televisão. Portanto, uma coisa eu não é explanans do turno (195) do adulto porque tem que ser água quente. Neste mesmo turno (195), uma coisa eu não torna-se explanandum para nunca vi essa televisão um dia... marcado no mesmo turno, e ainda nunca vi essa televisão um dia...é explanans de só vi na minha televisão (Veneziano,2003). Também, no turno (198) é mas eu não entendi .... que ela é dos chineses...., ela explica e justifica no mesmo turno. Quando a criança explica que, não entendi como sendo o motivo de porque só viu na televisão ( turno 197 do adulto) e porque ela é dos chineses justificando, portanto, sua dificuldade ainda maior de entender. 
O turno (202) espera...tô montando aqui, nos mostra uma conduta explicativa/ justificativa em que a criança solicita um tempo ao adulto para terminar sua ação no jogo. É como se ela dissesse : espera um pouco porque preciso de tempo para terminar isto que estou montando.

Uma explicação/justificação foi dada pela criança de maneira espontânea , como se observa no turno (182) é ... é ..... a lá... e tem que ficar mu:.:ito longe dela ...senão.... Esta conduta foi considerada necessária pela criança, quando ela fez um julgamento, ou seja, uma avaliação a respeito da situação em relação ao objeto: porque é uma televisão de raio tem que ficar muito longe dela senão pode haver problemas, como podemos interpretar.

É interessante observar o turno (176) já viu raio?, que apresenta uma conduta explicativa/justificativa formulada em forma de pergunta. Aqui, podemos inferir que o adulto solicita uma explicação sobre a televisão em (175) de raio?.. que qui é isso? e a criança responde : porque se você já viu raio então é uma televisão disso que você já viu. Concluímos então que o turno (176) é explanans do turno (175) e explanandum do turno (178) então é uma televisão de raio....aí...no buraco. Esta explicação da criança é caracterizada pela tautologia, quando, segundo Wallon (1986), a criança explica um termo pela repetição do mesmo. Chalhub (2002), assinala como sendo uma metalinguagem em que um termo, referente ao objeto, opera um conhecimento a respeito deste, ao mesmo tempo em que explica este termo.

Dos desencadeadores de tutela apontados por Hudelot (1987), temos: a) formulação pouco compreensível da criança no turno (172) com pedido de reformulação , turno (173) e refoemulação da criança em (174). Também vemos no turno (184) da crianca que desencadeia o pedido de reformulação pelo adulto ( 185) e a reformulação da criança no turno (186) ; b) denominação ambígua para a adulto em (174) com pedido de especificação em (175) feita pelo adulto e resposta da crianca turno ( 176/178). Outro pedido de especificação do adulto em (179) desencadeando o turno (180) e novamente vemos nos turnos (189) desencadeando (190) e ( turnos ( 197) com (198); c) mensagem atenta do adulto á fala da criança com reprise da colocação das palavras e aceite ou concordância no turnos (180) e (181), em (186),(187) e ( 188), em (190) e (191), em (192), (193), (194), em ( 198) e (199) e em (212) e (213); d) denominação com pedido de descrição nos turnos ( 179), (180) e em ( 183) e (184) e em (200), (201) e (202); e) qualificação e pedido de justificação nos turnos (194), ( 195), (196) e em (211) e (212). 
Hudelot (1987), também refere que há outros tipos de desencadeadores como o silêncio das crianças, observado no turno (209), desencadeando o turno (210) do adulto.

Exemplo 3: [ Criança e adulto estão montando a entrada do sítio e testando a passagem do carro por entre os blocos encaixados.]

48-A: mas eles não conseguem passar...vou por o telhado asSIM... seRÁ que eles PASsam? vamos ver

49-N: de carro...não devem passar ... \{a pé ((faz tentativa com o carro montado de passar por debaixo da casa montada))

50-A:

\{a pé deve ...de carro não ? passou ou não passou?

51-N: não...não porque eles estão muito AL::to

\section{Comentários}

$\mathrm{O}$ adulto, neste segmento, desempenha a modalidade de tutela de direçãoparticipação, pois direciona a criança sugerindo-lhe idéias e facilitando a atividade, enquanto ela aceita e participa apropriando-se das idéias e significações,(Verba, 1999). Notamos, pela posição 0 no diálogo , turno (48) mas eles não conseguem passar...vou por o telhado aSSIM... SeRÁ que eles PAssam? vamos ver, o direcionamento do adulto enquadrando a criança no jogo e incitando-a a prosseguir com a ação de faz-deconta.(Hudelot,1987). Esta conduta desencadeia a conduta explicativa/justificativa do turno (49), de carro.....não deve passar ...\{́a pé . O explanandum fornecido pelo adulto , será que eles passam (48), conduz ao explanans dado de carro ...não deve passar (49). Esse explanans torna-se explanandum para a criança que introduz o explanans \{ a pé, com os termos mas e deve passar elididos. A criança utiliza o operador mas para articular dois argumentos com orientação oposta.(Koch,2002).

No turno (50) \{a pé deve ...de carro não ?, o adulto faz uma retomada do enunciado da criança e, após outra pausa , questiona ação no faz-de-conta da criança (passou ou não passou?), indicando a posição 1 no diálogo, que favorece a produção da 
próxima seqüência de explicação do turno (51) não...não porque eles estão muito AL::to. Aqui, a criança faz uso do conectivo porque, para inserir uma explicação sobre a ação realizada com o objeto no jogo e, ao mesmo tempo, justificar sua proposição, (Koch, 2002).

Exemplo 4: [(A) e (J) combinam montar uma casa e a mesa da cozinha, para contextualizar a cena..]

138-J: tem mesa (( olha A))

139-A: que mais?

140-J: a minha MEsa é asSIM ... ela é grudada.... e ela a::bre e fe::cha...aQUI... ela tá fechada... e aQUI... ela tá aberta... aqui ela tá fecha::da ... e aqui ela tá abe.:.rta (( gestos com as mãos para mostrar ))

(...)

164-J: não.... a mesa é e.:.::ssa (( mostra a peça))

165-A: essa é a MEsa?

166-J. é... pode ser... porque mesa é asSIM

167-A: mas você disse que a mesa é de abrir e feCHAR

168-J: ((silêncio, amarra o tênis)) seRÁ que ela vai feCHÀ/?.. aBRÍ/ ...e feCHÁ/?... NÃO.....eu tive uma idÉ::ia ((olha A))

169-A: o que cê/ teve de idéia?

170-J: (( volta a amarrar o tênis)) ah não.... mas não é:...... ... não fecha tem ( ) ... ah ((termina de amarrar o tênis))

171-A: o que que foi?

172-J: mas a mesa pode sê/... sem abrí/ e fechá/ (( olha para A))

173-A: tá bom ...pode ser sem \{abrí/ e fechá/

174- J: \{na casa do meu PAi...na casa do meu pai lá tem uma ... uma mesa na salinha... num abre e fecha

175-A: não?

176-J: não preci:::sa né?

177-A: tá bom.. não precisa ... LÁ na vó ...a mesa também não abre e fe::cha.. né? 


\section{Comentários}

Notamos aqui, que criança e adulto negociam sentidos e partilham significados. Anteriormente, a criança havia explicado seu referente de mesa com base na sua experiência de vida, turno (140). Por causa da montagem, ela decidiu construir sua mesa apoiando-se em outro referencial,( turno (164) não... a mesa é e:.::ssa). O adulto busca obter a confirmação, posição 3 no diálogo, no turno (165) essa é a Mesa?. No turno (166) é... pode ser... porque mesa é asSIM, notamos uma explicação tautológica (Wallon, 1986) do tipo mesa pode ser assim porque mesa é assim, ou metalingüística, operação de explicar um termo segundo ele mesmo, segundo Chalhub (op. cit.).

Em decorrência do retorno do adulto, posição 3, (Hudelot, 1987), turno (167) mas você disse que a mesa é de abrir e feCHAR, ao primeiro referente da criança , (J) repensa como seria montagem da mesa, de acordo com este referencial. Esta tutela do adulto conduz a criança a repensar os referentes. No turno (172) mas a mesa pode sê/... sem abríl e fechá/, verificamos o uso do operador mas, que contrapõe argumentos orientados para idéias, opiniões e conclusões contrárias (Koch,2003), para iniciar sua justificativa no novo referente. $\mathrm{O}$ adulto (A) aceita a argumentação de (J), porém ela continua explicando/justificando no turno (172), ou seja, fazendo referências ao novo referente, e reforçando seus argumentos como no seu próximo turno (174) na casa do meu PAi...na casa do meu pai lá tem uma ... uma mesa na salinha... num abre e fecha, com base na experiência com o referente mesa. Segundo Piaget (1975), o jogo simbólico se constitui em manifestação da função semiótica. O pensamento representativo se inicia, quando "o significante" se diferencia do "significado" e é, a partir de diferentes formas de significação, que diferentes formas de representação podem se desenvolver. Neste exemplo, o jogo, além de possibilitar a criança estabelecer relações entre significantes e significados do objeto mesa na interação com o adulto, através das condutas explicativas/justificativas, favoreceu a partilha de significados e a negociação de sentidos, para prosseguirem no jogo. Como vemos, a tutela do adulto produziu um efeito positivo na tutela complementar, pois na troca interativa, o adulto levou a criança a (re)pensar e ampliar a significação do elemento mesa, introduzindo outros significantes ao seu significado dado, (François, 1986). O adulto assumiu a posição 1 no turno (171) o que que foi ?, que desencadeou a conduta explicativa/justificativa e a posição 3, no turno (173) tá 
bom ...pode ser sem [abrí/ e fechá/, em que o adulto parafraseia a criança reformulando sua proposição em (167) mas você disse que a mesa é de abrir e feCHAR.

No turno (175) não? , o adulto, na posição 3 , conforme Hudelot (1987), confirma o turno (174), desencadeando a explicação/justificação da criança do turno (176), não preci:::sa né , que pode ser entendida: por causa disso não precisa então.

Podemos observar, neste segmento, os desencadeadores de tutela: a) formulação pouco compreensível com pedido de reformulação e reformulação da criança nos turnos (164), (165), (166); b) qualificação e pedido de justificação , turnos ( 167) e (168) e em ( 173) e (174).

B) Condutas explicativas/justificativas nos episódios de encadeamento de eventos

As próximas situações a serem analisadas estão relacionadas aos episódios de idéias e encadeamentos de eventos, que se desenrolaram em vários temas: a) temas relacionados à experiência cotidiana, b) temas relacionados à histórias imaginadas. Os temas baseados na experiência cotidiana da criança envolvem as ações de ir á escola, jantar, almoçar,etc. Os temas referentes às histórias imaginadas se diversificam entre as histórias inventadas baseadas em fábulas, desenho animado,etc.

Em nosso corpora, uma criança ( $\mathrm{J}$ ) desenvolveu o tema baseado na vida cotidiana. Três crianças $(\mathrm{B}, \mathrm{G}, \mathrm{JP})$ criaram histórias com os personagens Emília e Visconde, independente do contexto do Sítio do Pica-Pau Amarelo, e uma criança (N) conduziu seu jogo para este último contexto.

A seguir, avaliaremos as condutas explicativas/justificativas pertinentes aos episódios de idéias e encadeamentos de eventos, exemplificando os vários temas encontrados.

Exemplo 5: [(A) e (J) montaram a casa com os blocos e cada um assume um personagem que interage na casa, numa situação do dia a dia.]

232-J: pode tomá/ café (( com mudança de voz )) 
233-A: cê não vai tomar café coMIgo?... cê não vai comê/ pão coMIgo?(( com mudança de voz ))

234-J: eu já coMI .....eu acordei priMEIro que você (( com mudança de voz))

235-A: ah:: é verdade....(( mexe com o boneco)) pronto... eu JÁ tomei café ((com mudança de voz))

\section{Comentários}

A dinâmica interativa de acordo com Verba (1999), neste exemplo, é de coelaboração, portanto tanto o adulto quanto a criança participam da gestão do jogo, apresentando idéias, realizando construções simbólicas e articulando seqüências de eventos eventos e/ou propondo e justificando cada uma suas proposições. Aqui, podemos verificar a ocorrência da conduta explicativa/justificativa presente na fala dos personagens, que participam da história fictícia. Verba (1990) revela que há distinção entre enunciados com propósito de jogo, que cumprem a função de negociar temas, escolher cenários e etc, e os que surgem nas situações, em que os parceiros representam papéis, que são os in frames ou acting (como os enunciados que aparecem na comunicação entre doente e médico, por exemplo). Fávero (2002:74) ressalta que " frame é uma noção interativa em que a interpretação contextual é negociada pelos falantes, refletindo-se direta ou indiretamente em suas trocas conversacionais".

Nas passagens a seguir, adulto e criança têm seus personagens pré-estabelecidos e caracterizados pela voz. No turno (233) cê não vai tomar café coMIgo?... cê não vai comêl pão coMIgo?, o adulto convida a personagem de (J) para fazer parte da ação de faz-deconta. A personagem de $(\mathrm{J})$ recusa, explicando seu motivo, como observamos no turno (234) eu já coMI .....eu acordei priMEIro que você. Notamos que, eu já coMI é explanans do explanandum verbalizado pelo adulto no turno (233) cê não vai tomar café coMIgo. Este explanans passa a ser o explanandum do próprio explanans fornecido pela criança, eu acordei priMEIro que você, para justificar sua resposta. Podemos inferir : eu não vou tomar café porque eu já tomei porque eu acordei antes de você. Assim, o adulto mesmo representando um personagem, assume a posição 1 no diálogo de acordo com Hudelot (1987), incitando a criança a uma ação, como no turno (233), e/ou provocando a explicação/justificação como no turno (234). Neste fragmento, o que desencadeou a tutela 
do adulto foi a criança ter-se retirado da interação no turno( 232), quando solicita o adulto que "vá tomar café", sem incluir-se na situação.

Exemplo 6: [A criança termina de montar a porta do sítio (inspirada pela história do “Sítio do Pica-Pau Amarelo") e decide fazer um passeio com o carro.]

66-A: certo..e será que eles passam agora aqui DENtro?

67-N: não ... mas agora eles SÓ vão andar de CArro

68-A: andar por onde ...por AI?

69-N: é por AÍ ...para a pedra MÁgica... a pedra mágica é que uma pessoa é BRUxa ...tem uma filhinha ...é boaZInha... que ela tem um neGÓcio lá ... aí a Narizinho vira pedra 70-A: porque?

71-N: porque ela não gosta DEla ...do NariZInho

72-A: a bruxa não gosta do NariZInho?

73-N: ((silêncio))

74-A: nem dos outros persoNAgens?

75-N: NEm...nem do Visconde ...da Emília

76-A: e porque só a Narizinho virou PEdra?

77-N: porque ela tava passeANdo ...passeANdo e não sabia... eh (( fez um gesto dde endurecer o corpo como se mostrasse que estava dura ))

78-A: entendi

\section{Comentários}

Neste fragmento, ocorre uma seqüência de encadeamentos discursivos que exemplificam a rede discursiva entre: proposições da criança - intervenções do adulto reação da criança, sugeridas por Hudelot (1987). No turno (66) certo...e será que eles passam agora aqui DENtro?, o adulto assume a posição 1 no diálogo, solicitando uma reformulação e incitando a criança à ação de faz-de-conta. A seguir, no turno (67) não ...mas agora eles SÓ vão andar de CARro, a criança, ao se opor à proposição do adulto, explica sua intenção no jogo e justifica sua ação, ao mesmo tempo, utilizando o operador mas, para iniciar seu argumento. Como vemos, ao explanandum (66) eles passam aqui 
agora aqui dentro?, a criança produz um explanans justificando a resposta negativa em (67). O pronome eles é usado em elipse, referindo-se aos bonecos e a seus respectivos carrinhos. Este turno desencadeia nova intervenção do adulto, (68) andar por onde ...por $A I ?$, que assume a posição 1 , e provoca a conduta explicativa/justificativa da criança do turno (69) é por AÍ ...para a pedra MÁgica... a pedra mágica é que uma pessoa é BRUxa ...tem uma filhinha ...é boaZInha... que ela tem um neGÓcio lá ... aí a Narizinho vira pedra, confirmando e aceitando a proposição do adulto em, andar por ai (68). Ao mesmo tempo em que informa, a criança explica e justifica sua ação com explanandum e explanans, presentes no mesmo turno de fala, partilhando, assim, sua intenção no jogo.

Novas intervenções são realizadas pelo adulto, como vemos nos turnos (70),(72),(74),(76) que assume as posições 1,3,2,2 respectivamente, ( Hudelot, 1987), e favorecem a produção de explicações/ justificações na criança..Observamos nos turnos (71), porque ela não gosta DEla ...do NariZInho e (77), porque ela tava passeANdo ...passeANdo e não sabia... eh (( fez um gesto como se mostrasse que estava dura, sem movimento )), o uso do operador porque pela criança para introduzir sua explicação, que se complementa com uma informação não verbal. Com o gesto de endurecer o corpo, podemos compreender que ela quis dizer que a personagem ficou dura, ou seja, transformou-se em pedra. As intervenções do adulto surgem com o intuito de sustentar a atividade da criança, favorecer a troca de significações e idéias exigida pelo caráter ficcional e promover a gestão do jogo e da interação. Verba $(1990,1999)$. Este efeito de sustentar a atividade da criança pelo adulto, através de suas perguntas incentivou a progressão temática, possibilitando à criança de explicar, como se estivesse narrando, e de narrar, explicando, (François, 1986).

Como podemos observar, temos os desencadeadores de tutela: a) denominação (turno (67)) com pedido de descrição (turno (68)); b) qualificação com pedido de descrição ( turnos (69) e (70), respectivamente) e c) denominação ambígua e pedido de especificação nos turnos (76) e (77), respectivamente. Também observamos, como desencadeador, o silêncio da criança no turno (73) em resposta ao turno ( 72 ) levando o adulto ao turno (74) para retomar o diálogo.

Exemplo 7: encadeamento de idéias e eventos - história imaginada utilizando os personagens do sítio do Pica-Pau Amarelo. 
Situação (a) : [(B) está empurrando o carro que desmonta e então, ela encaixa novamente. Tira o carrinho para fora do tapete e empurra por um trajeto longo.

92-A: nossa que estrada longa hein?

93-B: ((sim com a cabeça, vira o carro e retorna pelo mesmo trajeto))

94-A: já está voltando?

95-B: já... e agora vai ser um caminho mais longo ainda

96-A: nossa assim eles vão ficar muito cansados

97-B: e é a Emília que tá dirigindo (( certo momento ela pára o castelo))

98-A: aí eles chegam?

99-B: eles chegam .. deixam o castelo aqui... e vão pra ( ) bem longa

100-A: aí o castelo fica aqui?

101-B: uh uh porque .. a Emília já tá dormindo

102-A: mas ela tá dirigindo... ela não pode dormir dirigindo

103-B: mas ela já tá dormindo

104-A: então é o Visconde que tem que dirigir

105-B: mas o Visconde também está dormindo

106-A: mas como pode dirigir dormindo?

107-B: é que ele tem o periquito dele e o periquito que tá dirigindo

108-A: e onde tá esse periquito?

109-B: ah ...(( expressão pensativa, olha A)) ele chamava guaxinim

110-A: o periquito chamava guaximim?

111-B: é

112-A: tá e cadê ele?

113-B: é que ele tá escondido embaixo do carro ((olha A))

114-A:coitado do periquito.. embaixo do carro?

116-B: ((risadas, olha A))

\section{Comentários}

As intervenções do adulto tratam de sustentar a atividade da criança, auxiliando sua atividade de narrar a história imaginada, portanto, temos a modalidade sustentação da 
atividade da criança, (Verba,1999). As condutas explicativas/justificativas compreendem principalmente características de eventos e ações dos personagens, graças aos recursos lingüísticos de seqüenciação típicos da narrativa. Ao contar sua história, (B) desencadeia, em seus enunciados e ações, a conduta tutelar do adulto, para que ela utilize as condutas explicativas/justificativas. Neste caso, ela recorre à utilização de operadores lingüísticos de força argumentativa, presentes nas condutas explicativas/justificativas, assinalando seu aspecto argumentativo nos enunciados da criança, (Koch, 2003).

O adulto na posição 1 do diálogo, ( Hudelot, op.cit), no turno (94), já está voltando?, favorece a conduta explicativa/justificativa da criança. (B) justifica para o adulto o explanandum, voltando (94) com o explanans, ... agora vai ser um caminho mais longo ainda, turno (95) e com o uso do operador e agora acrescenta, por sua vez, um argumento com função de introduzir conteúdos pressupostos,(Koch,2003). Portanto, quando ela diz: e agora vai ser um caminho mais longo ainda, pressupõe-se que o trajeto anterior não era tão longo como o que ela vai fazer agora. (turno 95).

$\mathrm{Na}$ conduta explicativa/justificativa utilizada nos turnos (97) e é a Emília que tá dirigindo e (99) eles chegam .. deixam o castelo aqui... e vão pra ( ) bem longa, a criança usa o operador $e$, para acrescentar argumentos a favor de uma determinada conclusão (Koch,2003).

No turno (98), ai eles chegam?, o adulto toma a posição 1 no diálogo, favorecendo a produção de uma justificação e explicação surgida no mesmo turno de fala, que fornece a causa e a motivação dos eventos e das ações no jogo. Podemos entender como sendo : eles chegam porque vão deixar o castelo aqui e vão deixar o castelo aqui porque vão para um lugar bem longe, turno (99). Portanto, temos: eles chegam é explanandum de deixam o castelo aqui, um explanans que passa a ser explanandum para o explanans dado em, vão para bem longe.

No próximo turno (101), uh uh porque .. a Emília já tá dormindo, (B) faz uso do operador porque para introduzir uma explicação relativa ao enunciado anterior do adulto, de posição 3, turno (100) aí o castelo fica aqui? . O adulto busca uma confirmação e a criança responde e justifica a sua resposta. Assim, fica aqui? (turno, 100) é explanandum para o explanans dado em (101), porque .. a Emília já tá dormindo, (Veneziano, 2003), com o verbo fica em elipse, (Koch,2003). Podemos interpretar o turno de (B): sim fica porque a Emília já tá dormindo. 
A seguir, a criança produz duas explicações /justificações desencadeadas pela posição 2, ( Hudelot, op.cit) posição em que o adulto retoma a a fala da criança e introduz uma complementaridade ao propor sua própria codificação. É uma posição em que o adulto apresenta uma questão e responde no lugar da criança. Vemos em (102) mas ela tá dirigindo... ela não pode dormir dirigindo, e em (104) então é o Visconde que tem que dirigir. Em ambos, a criança não aceita a proposição dada pelo adulto, e então justifica e explica sua proposição em (103) mas ela já tá dormindo e em (105) mas o Visconde também está dormindo, introduzidos pelo operador mas, que indica argumentos que se opõem em uma orientação contrária. (Koch,2003). Trata-se de uma negociação por parte da criança que busca, com a conduta explicativa/justificativa, manter sua intenção de que os personagens já estão dormindo. A modalidade de tutela aqui é negociação do tema, segundo Verba ,(1999).

O adulto, na posição 1, solicita em (106) mas como pode dirigir dormindo?, uma explicação. A criança, através do operador que, fornece esta explicação . Assim, para o explanandum verbalizado pelo adulto, como pode dirigir dormindo, temos o explanans dado pela criança no turno (107), é que ele tem um periquito, que torna-se explanandum para o explanans, verbalizado no mesmo turno da criança, que tá dirigindo. A conduta explicativa/justificativa da criança levou o adulto mudar sua conduta. $\mathrm{O}$ adulto aceita a proposição da criança, e suas intervenções seguintes são para sustentar a fala da criança, portanto, modalidade de tutela de sustentação da atividade da criança, (Verba, 1999).

O adulto, na posição 1, ( Hudelot, op.cit), solicita uma explicação da criança em (112) tá e cadê ele?. (B) pressupõe, por esta pergunta, que (A) não sabe onde está o periquito porque não vê nenhum, então, ao explanandum cadê ele ?, ela apresenta o explanans, turno (113) é que ele está escondido embaixo do carro, (Veneziano, 203).

Logo nos primeiro turnos, observamos que o adulto busca o diálogo com a crianca. Observamos o silêncio da criança como desencadeador da tutela do adulto, turnos (92), (94). Temos outros desencadeadores em : a) denominação ambígua com pedido de especificação , turnos ( 101) e (102); (103) e (104); b) formulação pouco compreensível com pedido de reformulação e reformulação nos turnos (105), (106) e (107); c) denominação ambígüa com pedido de especificação nos turnos (108) e (109); (110) e (111); (112) e (113). 
Situação (b): [(JP) e (A) manipulam os bonecos, Emília e Visconde como se travassem uma batalha.. (A) manipula o boneco Emília e depois, esconde o boneco informando que ele tomou pó de pirlimpimpim e sumiu.

143-JP: óh o Visconde

144-A: o Visconde ficou pensando para onde foi a Emília ((voz natural))... onde foi a Emília? ((voz mudada))

145-JP: a espaçonave agora tztztz agora é uma....super arma... lança um monte ... monte ... de:.: água que pode assim óh ... ((joga-se no chão)) e morre afogada

146-A: mas ela usô/ o pó de pirlimpimpim e ela sumiu

147-JP: mas ele tá com outro poder... voa alto... ((levanta e faz movimento de vôo com a peça)) tzz $v z v z z$ ((onomatopéia))

148-A: e como faz para encontrá / a Emília....agora se ela usou o pó de pirlimpimpim?

149-JP: olha agora tz ((onomatopéia, joga-se no chão e olha A))

150-A: no::ssa:::: está cheio de água aí? ((aponta para o lugar onde ele está))

151-JP: não...ele vai sentí /...onde está a Emília assim...por debaixo da terra ((olha A))

152-A: ah:: ele vai sentir onde está a Emília? ... por debaixo da terra?

153-JP: vai sim... asSIM...quando faz assim ele acha ((começa a engatinhar e a rastejar a peça))

154-A: encontrô / ?

155-JP: mas acho que agora tem que tirá / a Emília

156-A: tirá / daonde?

157-JP: daonde ela tiVÈR

158-A: mas se tirá/ então eles vão achá/

159-JP: mas..mas...daí... aí ela pode corrê / até o Visconde e atirál lá onde está o Visconde (( aponta onde o Visconde está))

160-A: ah é ... então eu vou fazer isso.... vamos lá (( pega a Emília e coloca rápido junto do Visconde))

\section{Comentários}


Muitas das explicações observadas na dinâmica desta interação são dadas pela criança para direcionar a participação do adulto. A tutela, de acordo com Verba (1999), é a modalidade co-elaboração, pois criança e adulto propõem situações, idéias e participam, ambos, da gestão do jogo. Assim, na primeira explicação da criança, turno (145), quando ela diz: a espaçonave agora tztztz agora é uma.... super arma... lança um monte ... monte ... de::.: água que pode assim óh ... (( joga-se no chão)) e morre afogada, é que ela lançou no jogo uma proposição, indicando a mudança na espaçonave e na arma de guerra, (a espaçonave agora tztztz agora é uma....super arma... ), justifica a proposição da mudança com um porque implícito, como podemos inferir em (porque)... lança um monte ... monte ... de.:. água e, explica sua função em, que pode assim óh ... (( joga-se no chão)) $e$ morre afogada, ou seja, pode jogar água e, então, matar por afogamento. Portanto, a criança narra, explica, justifica , descreve, para articular sua explicação / justificação.Vemos que espaçonave é o explanadum para lança um monte ... monte ... de.:.: água que é explanandum para que pode assim óh ... (( joga-se no chão)) e morre afogada . (Veneziano, 2003). O adulto retoma, então, a proposição dada em momento anterior sobre a situação do jogo, turno (146) mas ela usô/ o pó de pirlimpimpim e ela sumiu que a criança recusa justificando o porque ao dizer, mas ele tá com outro poder (147). Para tal, ela inseriu sua justificação, utilizando o operador mas, que implica na oposição entre argumentos enunciados, que dão origem a conclusões contrárias, (Koch,2003). O adulto procura, então, se ajustar (148 e 150) na proposição da criança em relação à mudança na espaçonave, assumindo a posição 1 no diálogo. A criança fornece nova explicação no turno (151), não ... ele vai sentí / ..... onde está a Emília assim ... por debaixo da terra (( olha A)), pois mentalmente ela realiza outra mudança na espaçonave. Assim, sua conduta explicativa/justificativa tem intuito de explicar sua ação no jogo e marcar a atuação do adulto, segundo suas intenções. Quando o adulto busca uma confirmação, (posição 3) no diálogo, como ocorre no turno (154) encontrô /?, a resposta da criança se dirige para o adulto, explicando como este deveria atuar no jogo,(turnos, 155 e 157) .

Em (158), mas se tirál então eles vão achál , o adulto ( posição 2), lança uma proposição contrária à criança, iniciada pelo operador mas, desencadeando a produção de outra explicação dela em (159) mas..mas...daí... ai ela pode corrê / até o Visconde e atirál lá onde está o Visconde (( aponta onde o Visconde está)), direcionado o adulto em sua atuação. Podemos inferir que a intenção de (JP) é que o adulto tire seu boneco escondido, 
porque no faz-de-conta o adulto pode contra-atacar o boneco de (JP). Assim, este turno da criança é o explanans (ela pode corrê / até o Visconde e atirál lá onde está o Visconde) do explanandum do turno do adulto (158) eles vão achál , (Veneziano, 2003).

Observamos os desencadeadores de tutela: mensagem atenta - reprise da colocação de palavras - aceitação ou concordância em (151), (152) e (153); denominação ambígua pedido de especificação em (155) e (156) e em ( (157) e (158).

Exemplo 8: [A criança fez uma expressão corporal e o adulto adivinhou o que a criança estava dramatizando. $\mathrm{O}$ adulto pega os blocos e começa a fazer montagens.]

28-L: OPS... ...mas o que você tá fazendo?

29-A: CAlma.... VOcê tem que descobrir... NÃo vou falar não

30-L: tem que IMITÁ/ o bicho

31-A: não...mas eu vou monTÁ/ ele aqui porque eu mão sei IMITÁ/ esse bicho

32-L: qual que é

33-A: você vai ver:::

34-L: ah .. é uma cobra

35-A: como você sabe?

36-L: cobra não fica no chão?

37-A: fica... \{mas::::

38-L: $\quad\{$ então ... $(($ risada $))$...sô/ eu

\section{Comentários}

Após (L) sugerir o "jogo de adivinhação", criança e adulto "adivinham" alguns elementos através de expressão corporal. Assim, (A) introduz a adivinhação na montagem do bloco "Lego", sem comunicar a sua intenção. A criança questiona, então o adulto, buscando entender a mudança de regra no jogo, turno (28) OPS... ...mas o que você tá fazendo? . O adulto continua jogando como se a regra já tivesse sido pré-estabelecida em (29) CAlma.... VOcê tem que descobrir... NÃo vou falar não, assumindo a posição 0 no diálogo.(Hudelot, 1987). Tal conduta do adulto favoreceu o aparecimento da conduta 
explicativa/justificativa de (L) no turno (30) tem que IMITÁ/ o bicho, em que ele explica para o adulto a regra do jogo, como se o adulto não a tivesse entendido. É como se a criança pretendesse dizer ao adulto : porque tem que imitar o bicho e não isso que você está fazendo. A intenção do adulto era mostrar para a criança outra forma de jogar e incitála a usar as peças do jogo "Lego", como vemos no turno (31) não...mas eu vou monTÁ/ ele aqui porque eu mão sei IMITÁ/ esse bicho. Verba (1990) chama esta dinâmica interativa de direção-participação, pois o adulto sugere, explica, facilita a atividade, introduzindo idéias e conduzindo o jogo. A criança participa respondendo às solicitações do adulto e apropriando-se da intervenção. No turno (35) como você sabe?, o adulto questiona (L), pedindo-lhe uma explicação . A criança explica com uma interrogativa, turno (36) cobra não fica no chão?, e justifica, no turno (38), utilizando então ... . Podemos entender como : é cobra porque cobra fica no chão, então, se está no chão é porque é cobra. Esta resposta implica na utilização da metalinguagem pela criança.. Chalhub (2002) refere-se à função metalingüística como uma linguagem b, referindo-se a linguagem a, ou seja, "uma operação de conhecimento acerca de algo é na relação eu - outro, uma tradução de linguagem, onde um termo A (...)". - referente ao objeto, opera um conhecimento acerca deste mesmo objeto - descrever, explicar, identificar (...) equivale a um termo B, (Chalhub, 2002:7). Para Wallon, é a manifestação do pensamento sincrético da criança, típico da tautologia.

Portanto vemos aqui, o desencadeador qualificação - pedido de justificação nos turnos (34), (35) e (36).

C) Análise quantitativa/perceptual das condutas explicativas/justificativas dos corpora

A partir deste momento, faremos um estudo quantitativo/ perceptual das condutas explicativas/ justificativas

Notamos que o jogo de adivinhação constitui de construções simbólicas com ações de faz-de-conta realizadas para fins de adivinhação. Das condutas explicativas/justificativas produzidas por esta criança, 16 estão presentes nos episódios de construção simples, 39 nos episódios de construção com ação de faz-de-conta (incluindo as que se produziram durante 
o jogo de adivinhação) e 11 integram o jogo de adivinhação. A seguir, prosseguiremos com nossa análise a partir das ocorrências de seqüências de explicação/justificação nas três formas de jogar que estão distribuídas como indicamos no quadro abaixo:

Quadro 1 : condutas explicativas/justificativas presentes nas diferentes formas de jogar em cada criança.

\begin{tabular}{|c|c|c|c|c|c|c|c|c|}
\hline & DUT & $\begin{array}{r}\text { S EXP } \\
\text { (Fol }\end{array}$ & $\begin{array}{l}\text { ATI } \\
\text { de j }\end{array}$ & $\begin{array}{l}\text { AS/JUS } \\
\text { gar) }\end{array}$ & ICA & & & \\
\hline $\begin{array}{r}\text { Criança } \\
\text { (idade) }\end{array}$ & $\begin{array}{l}\text { Con } \\
\text { Sim }\end{array}$ & $\begin{array}{l}\text { rução } \\
\text { blica }\end{array}$ & $\begin{array}{l}\text { Seq } \\
\text { Eve }\end{array}$ & $\begin{array}{l}\text { incia/ } \\
\text { os }\end{array}$ & $\begin{array}{l}\text { Sup } \\
\text { Bri } \\
\mathrm{N}^{\circ}\end{array}$ & $\begin{array}{l}\text { para outra } \\
\text { eira } \\
\qquad \%\end{array}$ & & $\begin{array}{l}\text { b-total } \\
\text { CEJ * }\end{array}$ \\
\hline & $\mathrm{N}^{\mathrm{o}}$ & $\%$ & $\mathrm{~N}^{\mathrm{o}}$ & $\%$ & & & $\mathrm{~N}^{\mathrm{o}}$ & $\%$ \\
\hline $\begin{array}{l}\text { B } \\
(5 \mathrm{a} 10 \mathrm{~m})\end{array}$ & 16 & 30,77 & 36 & 69,23 & 0 & 0 & & 14,48 \\
\hline $\begin{array}{l}\mathrm{G} \\
(5 \mathrm{a} 6 \mathrm{~m})\end{array}$ & 31 & 45,59 & 37 & 54,41 & 0 & 0 & 68 & 18,94 \\
\hline $\begin{array}{l}\mathrm{J} \\
(5 \mathrm{a} 2 \mathrm{~m})\end{array}$ & 45 & 64,29 & 25 & 35,71 & 0 & 0 & 70 & 19,50 \\
\hline $\begin{array}{l}\text { JP } \\
(5 \mathrm{a} 2 \mathrm{~m})\end{array}$ & 38 & 66,67 & 19 & 33,33 & 0 & 0 & 57 & 15,88 \\
\hline $\begin{array}{l}\mathrm{L} \\
(5 \mathrm{a} 2 \mathrm{~m})\end{array}$ & 38 & 55,88 & 0 & 0 & 30 & 44,12 & 68 & 18,94 \\
\hline $\begin{array}{l}\mathrm{N} \\
(5 \mathrm{a} 4 \mathrm{~m})\end{array}$ & & 81,82 & 08 & 18,18 & 0 & 0 & 44 & 12,26 \\
\hline TOTAL & 204 & 56,82 & 125 & 34,82 & 30 & 8,36 & 359 & 100 \\
\hline
\end{tabular}

Obs: 1) CEJ: condutas explicativas/justificativas.

2) $\mathrm{N}^{\mathrm{o}}=$ número de ocorrências

Como podemos evidenciar pela indicação da tabela 1, nas ocorrências de condutas explicativas/justificativas, produzidas pelas crianças, predominam mais a categoria 
construção simbólica que a de idéias e encadeamento de eventos. As crianças (J), (JP) e (N) apresentaram ocorrências maiores, com (J) indicando 64,29\% de construções simbólicas em relação a 35,71\% em idéias e encadeamento de eventos, (JP), com $66,67 \%$ e $33,33 \%$; e a criança $(\mathrm{N})$, a maior freqüência que as demais, indicando $81,82 \%$ e $18,18 \%$, respectivamente.

As crianças (B) e $(G)$ produziram mais condutas explicativas/justificativas na categoria idéias e encadeamento de eventos, com 69,23\% e 54,41 \% ,cada uma, respectivamente contrapondo-se à categoria construções simbólicas, com 30,77\% e 45,59\% , respectivamente.

Como assinalamos anteriormente, que as construções simbólicas podem surgir durante os episódios de idéias e encadeamento de eventos. No jogo de adivinhação, muitas construções simbólicas também integravam a atividade. Assim, a criança (L) apresentou ocorrência maior em relação às construções simbólicas do que no jogo de adivinhação, $52,22 \%$ e $44,88 \%$ respectivamente.

Os episódios de construção simbólica, como já dissemos, aparecem antes dos episódios de idéias e encadeamento de eventos, podendo também ocorrer durante a composição do cenário ou dos personagens, solicitados pelo jogo. As condutas explicativas e justificativas se distribuíram, nesta categoria, como veremos na tabela abaixo.

Quadro 2 : condutas explicativas/justificativas presentes nas construções simbólicas em cada criança. 


\begin{tabular}{|c|c|c|c|c|c|c|c|c|}
\hline \multicolumn{9}{|c|}{ CONDUTAS EXPLICATIVAS/JUSTIFICATIVAS - CONSTRUÇÕES SIMBÓLICAS } \\
\hline $\begin{array}{l}\text { Crianças } \\
\text { (idade) }\end{array}$ & $\mathrm{N}^{\mathrm{o}}$ & $\%$ & $\begin{array}{r}\mathrm{CO} \\
\mathrm{FAZ} \\
\mathrm{N}^{\circ}\end{array}$ & $\begin{array}{c}\text { ÇÃO DE } \\
\text { CONTA } \\
\%\end{array}$ & $\mathrm{~N}^{\mathrm{o}}$ & RIO & $\mathrm{N}^{\mathrm{o}}$ & $\%$ \\
\hline $\begin{array}{c}\text { B } \\
(5 \mathrm{a} 10 \mathrm{~m})\end{array}$ & 02 & 12,50 & 05 & 31,25 & 09 & 56,25 & 16 & 7,21 \\
\hline $\begin{array}{c}\mathrm{G} \\
(5 \mathrm{a} 6 \mathrm{~m})\end{array}$ & 07 & 22,58 & 17 & 54,84 & 07 & 22,58 & 31 & 13,96 \\
\hline $\begin{array}{c}J \\
(5 \mathrm{a} 2 \mathrm{~m})\end{array}$ & 27 & 60,00 & 06 & 13,34 & 12 & 26,66 & 45 & 20,27 \\
\hline $\begin{array}{c}\mathrm{JP} \\
(5 \mathrm{a} 2 \mathrm{~m})\end{array}$ & 0 & 0 & 39 & 100 & 0 & 0 & 39 & 17,57 \\
\hline $\begin{array}{c}\mathrm{L} \\
(5 \mathrm{a} 2 \mathrm{~m})\end{array}$ & 16 & 29,10 & 39 & 70,90 & 0 & 0 & 55 & 24,77 \\
\hline $\begin{array}{c}\mathrm{N} \\
(5 \mathrm{a} 4 \mathrm{~m})\end{array}$ & 16 & 44,45 & 13 & 36,11 & 07 & 19,44 & 36 & 16,22 \\
\hline TOTAL & 68 & 30,63 & 119 & 53,60 & 35 & 15,77 & 222 & 100 \\
\hline
\end{tabular}

Obs: 1) CEJ: condutas explicativas/justificativas

2) $\mathrm{N}^{\mathrm{o}}$ : número de ocorrências

A categoria construção simbólica com ação de faz-de-conta pode ser considerada como a de maior ocorrência de condutas explicativas/justificativas, como atestam os sujeitos (B), (G), (JP) e (L). Nas crianças (N) e (J), observamos uma ocorrência maior na categoria de construção simbólica simples.

Em relação à tutela do adulto, constatamos que a maior parte das explicações/justificações formuladas pelas crianças foi desencadeada pela tutela do adulto, como veremos mais adiante. Primeiramente, trataremos das explicações/ justificações produzidas espontaneamente pela criança. Estas produções aparecem nos corpora, sempre que a criança teve a necessidade de explicar/justificar ações, intenções solicitadas pelo contexto, ou em momentos de dificuldade na realização de uma atividade. Neste sentido, registramos a ocorrência de 39 condutas explicativas/ justificativas espontâneas nos corpora, representando $10,86 \%$ do total.

145-B: é....agora vamu/ passear? (( coloca o carrinho no castelo)) 
146-A: vamu/ ((observa))

147-B: (( faz o carro passar pela escada)) o meu óh ... já desce.. já desce com o carro

148-A: tá ((olha B)) o meu também (( faz igual B))

\section{Comentários}

A criança apresenta uma proposição para o adulto no turno (145), que a aceita sem restrições. A dinâmica tutelar, segundo Verba (1999), é a de co-elaboração, pois tanto a criança como o adulto participam do jogo com idéias e encadeamento de eventos e construções simbólicas, buscando coordenação intra e inter individual com interesse na gestão do jogo. A explicação/justificação da criança, no turno (147) não foi solicitada pelo adulto, mas a criança sentiu necessidade de explicar sua ação e intenção no jogo. Podemos interpretar como: o meu carro, olha, já desce porque já desce com o carro.

As produções espontâneas, que se sucederam no jogo, apareciam nos momentos em que a criança se dirigia ao adulto. Assim, pela conduta explicativa / justificativa, ela se antecipava a explicar sua intenção no jogo, evitando uma recusa ou intervenção do adulto. Desta forma, ela partilha o significado da ação, objeto ou intenção, na medida em que fornece argumentos antecipadamente, para conseguir a adesão do adulto e, inclusive, para conduzi-lo na atividade. Outras produções espontâneas estavam relacionadas às intenções e aos estados internos, como veremos a seguir.

116-N: precisa apertar (( pega os blocos e tenta encaixar com força))

117-A: conseguiu apertar?

118-N: ((sim com a cabeça, brinca com o cortador de grama))

119-A: ((observa))

120-N: aÍ.....só falta uma coisa ........ espera um pouco

\section{Comentários}


Neste segmento, (N) monta um objeto (cortador de grama) e fica brincando. De repente, tem uma idéia e remonta o objeto, acrescentando outros blocos. Ela não diz ao adulto sua intenção, mas a criança explica/justifica a realização de outra construção simbólica, como podemos perceber pelo turno (120) aÍ......só falta uma coisa espera um pouco. Com o uso do marcador aí, ela introduz sua proposição indicando a progressão no jogo. É como se dissesse : só falta uma coisa por causa disso espera um pouco, indicando ao adulto que ela precisa de um tempo para apresentar sua nova proposição no jogo.

A seguir, no quadro abaixo, apresentamos a distribuição das condutas formuladas de maneira espontânea em cada criança.

Quadro 3: condutas explicativas/justificativas produzydas espontaneamente em cada criança .

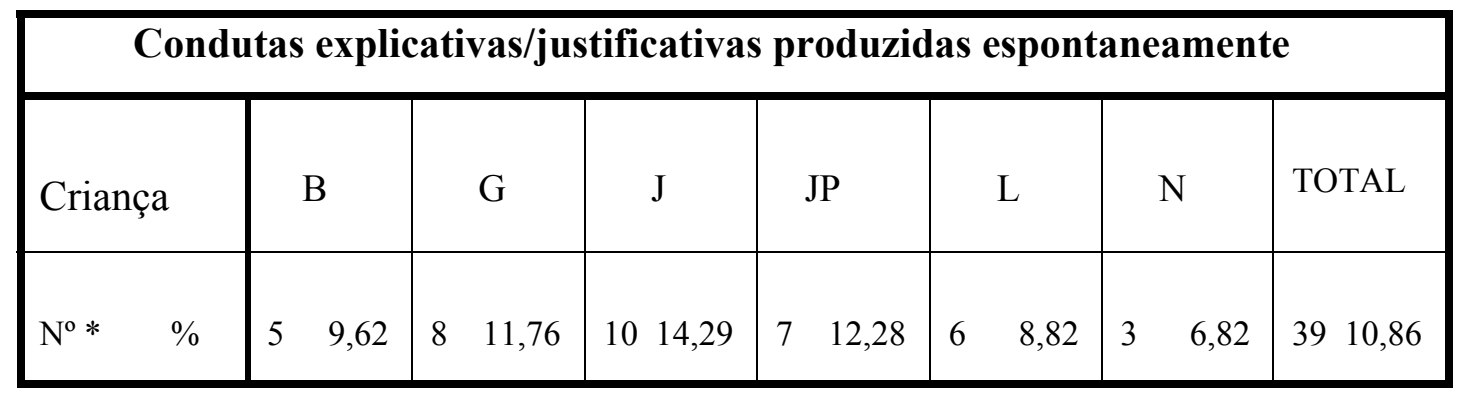

Obs: $* \mathrm{~N}^{\mathrm{o}}=$ número de ocorrências

Diante deste quadro, podemos constatar uma ocorrência bastante significativa das explicações/justificações das crianças, estimuladas pelas intervenções do adulto durante a interação. Como nosso interesse nesta pesquisa está nas condutas explicativas/justificativas produzidas pela criança e sua relação com a tutela do adulto, não discutiremos com mais detalhes as condutas produzidas espontaneamente. Dentre as condutas explicativas/justificativas que foram desencadeadas pelo adulto, avaliamos as produções de acordo com as modalidades de tutela de Verba (1999) e com a posição do adulto no diálogo 
de Hudelot (1987). Em relação às posições do adulto de Hudelot (1987), podemos conferir no quadro abaixo:

Quadro 4 : condutas explicativas/justificativas e a posição do adulto na conduta tutelar.

\begin{tabular}{|c|c|c|c|c|c|c|c|c|c|}
\hline \multicolumn{10}{|c|}{ CONDUTAS EXPLICATIVAS/JUSTIFICATIVAS - POSIÇÃO DO ADULTO } \\
\hline \multirow{2}{*}{ CRIANÇA } & \multicolumn{2}{|c|}{ P0 } & \multicolumn{2}{|c|}{ P1 } & \multicolumn{2}{|c|}{$\mathbf{P 2}$} & \multicolumn{2}{|c|}{ P 3} & \multirow{2}{*}{ (ocorrências) } \\
\hline & $\mathrm{N}^{\mathrm{o}}$ & $\%$ & $\mathrm{~N}^{\mathrm{o}}$ & $\%$ & $\mathrm{~N}^{\mathrm{o}}$ & $\%$ & $\mathrm{~N}^{\mathrm{o}}$ & $\%$ & \\
\hline $\mathrm{B}$ & 11 & 21,15 & 18 & 34,61 & 07 & 13,46 & 11 & 21,15 & 52 \\
\hline $\mathrm{G}$ & 09 & 13,24 & 20 & 29,41 & 10 & 14,71 & 21 & 30,88 & 68 \\
\hline $\mathrm{J}$ & 09 & 12,86 & 19 & 27,14 & 05 & 7,14 & 27 & 38,57 & 70 \\
\hline JP & 05 & 8,77 & 22 & 38,60 & 05 & 8,77 & 18 & 31,58 & 57 \\
\hline $\mathrm{L}$ & 12 & 17,65 & 24 & 35,69 & 10 & 14,71 & 16 & 23,53 & 68 \\
\hline $\mathrm{N}$ & 05 & 11,36 & 23 & 52,27 & 03 & 6,82 & 10 & 22,73 & 44 \\
\hline TOTAL & 51 & 14,21 & 126 & 35,10 & 40 & 11,14 & 103 & 28,69 & 320 \\
\hline
\end{tabular}

$\mathrm{O}$

Obs: 1) $\mathrm{P} 0=$ posição $0 ; \mathrm{P} 1=$ posição $1 ; \mathrm{P} 2=$ posição $2 ; \mathrm{P} 3$ = posição 3

2) $\mathrm{N}^{\mathrm{o}}=$ número de ocorrências

Como podemos examinar a partir da tabela, a posição 1 do adulto no diálogo favorece a produção de condutas explicativas/justificativas mais que as demais posições, apresentando maiores percentuais de ocorrência na maioria das produções. A posição 1 implica na conduta do adulto instigando, questionando a criança na interação e solicitando reformulações de suas respostas. Melo (1998) destaca que, nesta posição, estão as questões categoriais do tipo quem?, quando?, onde?, que podem ser respondidas só por um sintagma, e as do tipo como?, por quê?, que exigem uma resposta com predicação 
completa ao sintagma. Esta posição, portanto, leva a criança a reformular sua resposta, justificando/ explicando, e/ou dando argumentos para a questão colocada pelo adulto na interação.

Notamos que, na fala da criança (J), predominaram as condutas explicativas / justificativas, na posição $3(38,57 \%)$ e não na posição 1 (28,57). A posição 3 se destaca em segundo lugar em freqüência de ocorrências entre as crianças. Nesta posição, o adulto faz retomadas da fala da criança, avaliando, solicitando explicitações e confirmações, que podem vir acompanhadas de explicações e justificações.

A posição 2 apresenta a menor freqüência em relação às demais. A posição 2 está relacionada ao movimento discursivo em que, o adulto explicita ou complementa a fala da criança. As crianças que mais produziram condutas explicativas/justificativas nesta posição são (B), (G) e (L). Podemos concluir, pela análise dos corpora, que são as crianças que mais acrescentaram explicações e justificações ás complementações feitas pelo adulto, durante o jogo. A posição 0 é o momento do enquadramento ou direcionamento do adulto para a execução da tarefa ou mudança de tema . As condutas explicativas/justificativas nesta posição apareceram no corpora, em vários momentos, quando a criança não concorda com a proposição do adulto, e justifica/explica sua recusa/oposição, apresentando nova proposição com argumentos para obter a adesão do adulto.

As condutas explicativas/justificativas, realizadas pelas crianças estavam presentes nas diferentes dinâmicas de jogo entre adulto e criança. A seguir, examinaremos sua ocorrência nas modalidades de tutela de Verba (1999), distribuídas no quadro:

Quadro 5 : condutas explicativas/justificativas nas modalidades de tutela 


\begin{tabular}{|c|c|c|c|c|c|c|c|c|c|c|c|c|c|}
\hline \multicolumn{13}{|c|}{ CONDUTAS EXPLICATIVAS/JUSTIFICATIVAS - MODALIDADES DE TUTELA } & \multirow{2}{*}{$\begin{array}{l}\text { Sub } \\
\text { Total } \\
\text { CEJ }\end{array}$} \\
\hline $\begin{array}{l}\text { CRIANÇA } \\
\text { /idade }\end{array}$ & \multicolumn{2}{|c|}{$\begin{array}{l}\text { SUST. } \\
\mathrm{N}^{\mathrm{o}} \quad \%\end{array}$} & \multicolumn{2}{|c|}{$\begin{array}{l}\text { CO-ELAB. } \\
\mathrm{N}^{\mathrm{o}} \%\end{array}$} & \multicolumn{2}{|c|}{$\begin{array}{l}\text { D-PART. } \\
\mathrm{N}^{\mathrm{o}} \%\end{array}$} & \multicolumn{2}{|c|}{$\begin{array}{ll} & \text { D- } \\
\text { RESTR. } & \\
\mathrm{N}^{\circ} & \% \\
\end{array}$} & \multicolumn{2}{|c|}{$\begin{array}{l}\text { NEGOC. } \\
\mathrm{N}^{\circ}\end{array}$} & \multicolumn{2}{|c|}{$\begin{array}{ll}\text { OUTROS } & \\
\mathrm{N}^{\circ} & \%\end{array}$} & \\
\hline B & 08 & 15,38 & 27 & 51,92 & 07 & 13,46 & 0 & 0 & 05 & 9,61 & 0 & 0 & 52 \\
\hline $\mathrm{G}$ & 07 & 10,29 & 19 & 27,94 & 15 & 22,06 & 03 & 4,41 & 11 & 16,17 & 05 & 7,35 & 68 \\
\hline $\mathrm{J}$ & 23 & 32,85 & 18 & 25,71 & 07 & 10,00 & 0 & 0 & 11 & 15,71 & 01 & 1,42 & 70 \\
\hline JP & 14 & 24,56 & 15 & 26,32 & 0 & 0 & 0 & 0 & 22 & 38,60 & 0 & 0 & 57 \\
\hline $\mathrm{L}$ & 36 & 52,94 & 18 & 26,47 & 01 & 1,47 & 0 & 0 & 08 & 11,76 & 0 & 0 & 68 \\
\hline $\mathrm{N}$ & 22 & 50,00 & 0 & 0 & 09 & 20,45 & 0 & 0 & 03 & 6,82 & 05 & 11,36 & 44 \\
\hline TOTAL & 110 & 34,38 & 97 & 30,31 & 39 & 12,18 & 03 & 0,94 & 60 & 18,75 & 11 & 3,44 & 320 \\
\hline
\end{tabular}

Obs: 1) SUST.= sustentação da atividade da criança, CO-ELAB. = co-elaboração, D. PART. = Direção- participação, D.REST. $=$ Direção- restrita, NEGOC. $=$ Negociação, OUTROS = Outros .

2) $\mathrm{N}^{\mathrm{o}}=$ ocorrências.

3) $\mathrm{CEJ}=$ condutas explicativas/justificativas

Constatamos que as modalidades sustentação da atividade da criança e coelaboração são as que possibilitaram maior ocorrência de condutas explicativas/ justificativas. Notamos que as crianças $(B),(L)$ e $(N)$ realizaram com freqüência maior de $50 \%$, explicações/ justificações. Observamos na modalidade co-elaboração 51,92\% e na modalidade sustentação da atividade da criança 52,94\% e 50\%. Com a criança (J) também tivemos um percentual dominante, entre suas produções, na modalidade sustentação da atividade da criança. Com (JP) prevaleceu a modalidade negociação do tema, com $38,60 \%$.

Ao analisarmos as condutas de explicação realizadas nas modalidades de tutela e a posição do adulto que as desencadeou, obtivemos o quadro a seguir: 
Quadro 6 : condutas explicativas/justificativas nas modalidades de tutela e posição do adulto.

\begin{tabular}{|c|c|c|c|c|c|c|c|c|c|c|c|c|c|}
\hline \multicolumn{14}{|c|}{ CONDUTAS EXPLICATIVAS-JUSTIFICATIVAS } \\
\hline \multirow{3}{*}{$\begin{array}{l}\text { POSIÇÃo } \\
\text { Do } \\
\text { ADULTO }\end{array}$} & \multicolumn{12}{|c|}{ MODALIDADES DE TUTELA } & \multirow{3}{*}{$\begin{array}{l}\text { Sub - } \\
\text { ToTal } \\
\text { CEJ }\end{array}$} \\
\hline & \multicolumn{2}{|c|}{ SUST. } & \multicolumn{2}{|c|}{ CO-ELAB. } & \multicolumn{2}{|c|}{ D-PART. } & \multicolumn{2}{|c|}{ D-RESTR. } & \multicolumn{2}{|c|}{ NEGOC. } & \multicolumn{2}{|c|}{ OUTROS } & \\
\hline & & & $\mathrm{N}^{\circ}$ & & $\mathrm{N}^{\circ}$ & $\%$ & $\mathrm{~N}^{\mathrm{o}}$ & $\%$ & $\mathrm{~N}^{\circ}$ & $\%$ & $\mathrm{~N}^{\circ}$ & $\%$ & \\
\hline P 0 & 11 & 21,57 & 22 & 43,14 & 08 & 15,69 & 01 & 1,96 & 05 & 9,80 & 04 & 7,84 & 51 \\
\hline P 1 & & 42,86 & 31 & 24,60 & 16 & 12,70 & 01 & 0,79 & 19 & 15,08 & 05 & 3,97 & 126 \\
\hline P 2 & & 22,50 & 13 & 32,50 & 06 & 15,00 & 0 & 0 & 12 & 30,00 & 0 & 0 & 40 \\
\hline P 3 & & 31,06 & 31 & 30,10 & 12 & 11,65 & 01 & 0,98 & 24 & 23,30 & 03 & 2,91 & 103 \\
\hline TOTAL & 106 & 33,13 & 97 & 30,31 & 42 & 13,13 & 03 & 0,94 & 60 & 18,75 & 12 & 3,75 & 320 \\
\hline
\end{tabular}

Obs: 1) SUST $=$ sustentação da atividade da criança, $\quad$ CO-ELAB.$=$ co-elaboração, D. PART. $=$ Direção - participação, D.REST. $=$ Direção- restrita, NEGOC. $=$ Negociação, OUTROS $=$ Outros.

2) $\mathrm{N}^{\mathrm{o}}=$ ocorrências

3) $\mathrm{CEJ}=$ condutas explicativas/justificativas

Com base nestes dados, podemos concluir que dentre as condutas discursivas tutelares da posição 1, que desencadearam maior incidência de condutas explicativas/justificativas, estão na modalidade de tutela de sustentação da atividade da criança. Na posição3, encontramos maior incidência nas modalidades sustentação e coelaboração. Na posição 2, observamos a ocorrência das modalidades co-elaboração e negociação e a posição 0 , na co-elaboração.

Outro aspecto de nossa análise, com relação às condutas explicativas/justificativas produzidas pela criança, é o conteúdo do explanans. Veneziano (2003:50) lembra que a 
criança oferece explicações/justificações sobre os seguintes aspectos identificados nos corpora:

a) incapacidade de executar a ação : a criança sente dificuldade em realizar alguma atividade e fornece uma explicação / justificação a respeito.

214- A: que mais você disse que consegue montar...você disse que monta casa

215- L: é ...((olhando os blocos $))$ se tiver duas pecinhas destas... ((mostra o bloco)) eu consigo fazer o telhado

216- A: e si não tiver?

217-L: eu não consigo

b) características da ação a ser realizada: a criança fornece explicações / justificações com relação aos objetos, personagens ou ações.

156-B: --aí você chega lá e vai quebrá / o meu castelo aqui e aqui -- (( mostra, voz natural))

157-A: vai quebrá / ... mas o Visconde não quebra nada (( voz natural))

159-B: faz-de-conta

Ou em :

50-J: mas vamu/TÊ/ que precisá/ da roda porque é uma CAma de ROda

c) intenção ou avaliação da criança sobre a situação: ela fornece justificações e explicações referentes aos personagens do jogo, ou quando ela avalia suas ações.

239-A: você que quebro:::u...mocinha...por que você fez isso? ((com mudança na voz))

240-B: porque você tava dormindo e eu queria vigiá/ você....você deu uma paulada na:::na Emília...então você mereceu isso (( voz natural)) 
d) intenções ou planos alternativos para um futuro imediato: as explicações e justificativas recaem sobre uma proposição implicando numa alternativa para o que foi recusado, ou intenção solicitada.

187-A: que qui você vai fazê /?

188-J: fingi que eles tavam dormindo

Podemos examinar a distribuição das ocorrências de condutas explicativas/justificativas, de acordo com o conteúdo do explanans, como segue abaixo.

Quadro 7: conteúdo do explanans nas condutas explicativas/justificativas em cada criança.

\begin{tabular}{|c|c|c|c|c|c|c|c|c|c|c|}
\hline \multicolumn{11}{|c|}{ Conteúdo do explanans } \\
\hline \multirow{2}{*}{$\begin{array}{l}\text { Criança } \\
\text { (idade) }\end{array}$} & \multicolumn{2}{|c|}{$\begin{array}{l}\text { Incapacidade } \\
\text { de efetuar a } \\
\text { ação }\end{array}$} & \multicolumn{2}{|c|}{$\begin{array}{l}\text { Característica } \\
\text { da ação a ser } \\
\text { efetuada }\end{array}$} & \multicolumn{2}{|c|}{$\begin{array}{l}\text { Estados } \\
\text { internos e } \\
\text { avaliações }\end{array}$} & \multicolumn{2}{|c|}{$\begin{array}{l}\text { Intenções e } \\
\text { planos } \\
\text { alternativos }\end{array}$} & \multicolumn{2}{|c|}{ CE J * } \\
\hline & $\mathrm{N}^{o}$ & $\%$ & $\mathrm{~N}^{o}$ & $\%$ & $\mathrm{~N}^{\circ}$ & $\%$ & $\mathrm{~N}^{0}$ & $\%$ & $\mathrm{~N}^{\circ}$ & $\%$ \\
\hline $\begin{array}{c}\text { B } \\
(5 \mathrm{a} 10 \mathrm{~m})\end{array}$ & 1 & 1,92 & 25 & 48,08 & 16 & 30,77 & 10 & 19,23 & 52 & 14,48 \\
\hline $\begin{array}{c}\mathrm{G} \\
(5 \mathrm{a} 6 \mathrm{~m})\end{array}$ & 2 & 2,91 & 29 & 42,60 & 21 & 30,88 & 16 & 23,53 & 68 & 18,94 \\
\hline $\begin{array}{c}J \\
(5 \mathrm{a} 2 \mathrm{~m})\end{array}$ & 6 & 8,57 & 24 & 34,29 & 30 & 42,86 & 10 & 14,29 & 70 & 19,50 \\
\hline $\begin{array}{c}J P \\
(5 \mathrm{a} 2 \mathrm{~m})\end{array}$ & 0 & 0 & 27 & 47,36 & 15 & 26,32 & 15 & 26,32 & 57 & 15,88 \\
\hline $\begin{array}{c}\mathrm{L} \\
(5 \mathrm{a} 2 \mathrm{~m})\end{array}$ & 5 & 7,35 & 36 & 52,94 & 23 & 33,82 & 4 & 5,88 & 68 & 18,94 \\
\hline $\begin{array}{c}\mathrm{N} \\
(5 \mathrm{a} 4 \mathrm{~m})\end{array}$ & 3 & 6,82 & 24 & 54,55 & 15 & 34,09 & 2 & 4,55 & 44 & 12,26 \\
\hline TOTAL & 17 & 4,75 & 162 & 45,25 & 122 & 34,08 & 57 & 15,92 & 359 & 100 \\
\hline
\end{tabular}

* CEJ: condutas explicativas/justificativas. 
Verificamos inicialmente, que as explicações/justificações estão presentes em maior freqüência na categoria características da ação e, em seguida, pela categoria intenção e avaliação. Entendemos que, como a ocorrência de construções simbólicas (tabela 1) prevaleceu nos corpora, a incidência de ocorrências de explicações/justificações na categoria características da ação foi maior. A categoria intenção e avaliação aparece em segundo lugar. Esta categoria está presente tanto nos episódios de construções simbólicas como nos de idéias e encadeamento de eventos. Somente a criança (J) apresentou freqüência mais alta, na categoria intenção e avaliação, com um percentual de 42,86\%. Assim, constatamos que os explananda, no jogo de faz-de-conta, recaem mais nas ações e intenções do parceiro do jogo do que nas suas crenças e em seu conhecimento. 


\section{CONCLUSÕES}

A situação lúdica, sugerida nesse estudo, indica que a atenção está voltada para a montagem dos objetos, personagem, cenário e etc, que serão integrados numa seqüência de eventos e ações, no tempo e espaço, de acordo com a imaginação. No desenrolar do jogo de ficção, a criança cria situações de faz-de-conta que reproduzem situações próximas da vida cotidiana e de sua experiência de vida. Mesmo quando a criança fantasia, ela combina elementos imaginários (fictícios) e elementos de sua vivência (reais). Portanto, como verificamos, nos jogos de ficção o adulto não tem referência para direcionar a tarefa. No entanto, por ser um jogo com regras, o que supõe relações sociais, a participação do adulto implica em estimular a interação, favorecer a ação comunicativa e possibilitar a coerência discursiva e cognitiva que possibilita gerir o jogo.

Verba (1990) mostra que, para haver compreensão mútua entre os participantes do jogo é necessária a partilha de significações dos elementos construídos e a negociação de sentidos entre as proposições. A coordenação interindividual implica na partilha resultante da experiência e da imaginação. Como podemos constatar o jogo "Lego" favoreceu a construção de objetos, aos quais são atribuídos uma significação simbólica. As interações entre a criança e o adulto surgem com o objetivo de partilhar essa significação e é desse compartilhar que surge a regra,( Piaget, 1978:186).

Pelos dados coletados verificamos que, as condutas discursivas do adulto e da criança promovem a criação de um quadro referencial. O adulto solicita, explícita e implicitamente, a produção de condutas explicativas/ justificativas da criança a respeito dos elementos do jogo. A criança fornece explicações/ justificações de suas proposições, a fim de fazer o adulto compreender, aceitar ou modificar sua intenção. A criança explica para informar a seu interlocutor e partilhar a significação da sua ficção, revelando estados internos, intencionais e cognitivos.Á medida em que partilha com o parceiro as relações estabelecidas entre acontecimentos e significações dadas, também as condutas explicativas / justificativas aparecem com o intuito de fazer o parceiro mudar suas intenções, crenças e comportamento no jogo.

As condutas explicativas/justificativas apareceram nas diferentes formas de jogar com o "Lego". Notamos que prevaleceram nos episódios de construção simbólica, 
associadas a uma ação de faz-de-conta. A ação de faz-de-conta enfatiza a significação dada à montagem e as condutas explicativas/ justificativas complementam a informação sobre a significação ou aparecem como argumentos quando há necessidade, como justificação da significação ou intenção.

Nos episódios de idéias e encadeamento de eventos, as condutas explicativas/ justificativas são produzidas, não só com o intuito de caracterizar a ação e outros elementos que a integram (cenário, personagens etc), como também para apresentar intenções, avaliar situações, e comunicar planos alternativos.

Assim, as condutas explicativas/ justificativas no jogo de ficção com o "Lego" marcaram a presença do sujeito na partilha de significação de objetos, eventos e encadeamento de ações. Situações em que a imaginação da criança prevalece, o adulto solicita uma explicação para entender melhor a fantasia da criança e participar da atividade junto a ela. Em outras ocasiões, a criança se antecipa ao adulto, explicando e justificando para persuadir o adulto a aceitar sua proposição.

Quanto às dinâmicas interativas apresentadas por Verba (1990), com a pesquisa constatamos que as modalidades que prevaleceram a produção de explicações/justificações pela criança foram principalmente as modalidades de co-elaboração., sustentação da atividade da criança e negociação do tema. Na modalidade co-elaboração, ambos participantes (adulto e criança) apresentam suas proposições e explicam/justificam intenções e significados, para partilhar significações e estabelecer acordos. Uma característica discursiva observada nesta modalidade é o uso de operadores discursivos $e$, aí, daí indicando a progressão no jogo e/ou introduzindo uma intenção comunicativa.

$\mathrm{Na}$ modalidade sustentação da atividade da criança, verificamos que o adulto pode interpretar ou explicitar a atividade da criança de forma inadequada, ou melhor, não correspondendo às intenções da criança. .Em certos momentos, isto ocorre pelo aspecto imaginário (a criança cria alguma situação, objeto ou outro elemento do jogo com base na sua imaginação). A criança não comunica sua intenção, não partilha o significado dado, e por não entender a situação o adulto, solicita explicações/justificações. Isto pode acontecer devido à maneira da criança compreender o mundo, diferentemente do adulto que a interpreta com seu próprio "olhar". Neste momento, as condutas explicativas/justificativas surgem com objetivo de diminuir as distâncias entre as visões de mundo da criança e do adulto. (Halté, 1988; Hudelot, 2003). 
$\mathrm{Na}$ modalidade negociação do tema, a criança geralmente explica/justifica seu desacordo com o adulto buscando a adesão deste à sua proposição. Às vezes, o adulto solicita da criança uma explicação/justificação para poder compreender, e se ajustar à intenção da criança. Aqui, os operadores argumentativos porque, mas, que, são os mais utilizados pela criança para introduzir justificações/explicações.

Verificamos assim, as características argumentativas nas condutas explicativas/ justificativas desencadeadas pelo adulto, pois a articulação entre seus enunciados foi efetuada por operadores argumentativos como: e, só, também, ainda, nem, ligando enunciados que se constituem de argumentos de uma mesma conclusão; o uso do operador mas, contrapõe enunciados de orientações argumentativas diversas; e, também, somam argumentos de mesma conclusão; o uso da partícula se estabelece implicação entre enunciado antecedente e outro conseqüente; que, introduz uma justificação ou explicação sobre um ato de fala anterior ; agora, introduz no enunciado, conteúdos pressupostos e, ainda pelos encadeamentos que resultam de dois atos de fala, sendo que o segundo busca modificar a opinião do interlocutor ou fazer aceitar a opinião anunciada.

Segundo Hudelot (1987), desencadeadores são os enunciados da criança que promovem a conduta tutelar do adulto. Constatamos que as condutas explicativas/ justificativas da criança podem ser desencadeadas pela tutela do adulto, em todas as suas posições discursivas, porém predomina a posição 1 com o maior número de ocorrências, seguida da posição 3. Melo (1987) destaca que, na posição 1 impera os enunciados interrogativos do tipo que?,quem?como? onde? Porque?, e a posição 3 rege as reformulações parafrásicas, as retomadas dubitativas, os pedidos de confirmação e elucidação, as avaliações, os pedidos de especificações. Estes dois tipos de posição no diálogo possibilitam o desencadear de encadeamentos discursivos numa seqüênciação frástica, ( Koch,2002). A progressão discursiva ocorre por meio de sucessivos encadeamentos assinalados por marcas lingüísticas que estabelecem uma articulação entre os enunciados.

Portanto, as condutas explicativas/ justificativas surgiram em sua grande maioria, por solicitação do adulto no contexto comunicativo, inseridas no diálogo, resultantes da troca dialógica entre adulto e criança, como em $\mathrm{P} 1$ ou de movimentos discursivos do adulto, como em P3. A situação de tutela favoreceu a produção de condutas explicativas / justificativas mais para estimular a troca de significações e estabelecer acordos para o jogo, e bem menos para auxiliar a resolver situações de dificuldade da criança, principalmente 
devido a natureza do jogo de regras que são regulamentados por um código transmitido de geração em geração, quer por acordos momentâneos. ( Piaget, 1978: 184). Portanto, como observamos, nossa situação lúdica favorece os acordos entre os parceiros do jogo, mesmo implicando a ficção.

Desta maneira confirmamos as hipóteses lançadas na pesquisa de que as condutas tutelares do adulto favorecem a produção das condutas explicativas/justificativas produzidas pela criança no jogo de faz-de-conta com o objetivo principal de promover a partilha de significação e negociação de sentidos. Este aspecto é importante para profissionais que trabalham com a criança e utilizam do jogo de ficção, como os educadores, psicólogos, e particularmente aos fonoaudiólogos, espero que esta pesquisa contribua para reflexão de suas condutas na atuação terapêutica.

Retomando Verba (1990), temos dois processos considerados principais para a realização da partilha de significação: a transmissão direta e a confrontação. A transmissão direta ocorre pela denominação e complementos de informação. A confrontação se dá pela comparação entre representações e pontos de vista dos parceiros e no ajuste que cada um busca com o outro. A autora conclui que os jogos se organizam pela contribuição recíproca entre os parceiros do jogo, dado por esses dois processos assinalados, com intuito de garantir a compreensão mútua. Salienta que esses dois processos comunicacionais são responsáveis pelas redes de significação, formadas nas interações sociais e que constituem o quadro de referência que possibilita a cooperação nas atividades partilhadas ulteriores. Para a autora ( op. cit), a busca pela compreensão mútua entre os parceiros compreende as questões e pedidos de clarificação, as informações, os complementos de informação, as explicações e justificações, referindo ainda que as argumentações evidenciadas nos jogos servem tanto para clarificar o pensamento e assim ter a cooperação do parceiro, como para negociar um acordo. Enfim, conclui que o desenvolvimento destes dois processos comunicacionais, presentes na interação social é que consolidam a objetivação e a integração de saberes novos.

Por meio dos dados coletados, entendemos que são as condutas explicativas /justificativas que exercem esse papel importante no pensamento representativo. Para nós, as condutas explicativas / justificativas favorecem a construção do quadro de referência, necessário para o desenrolar do jogo, ao revelar estados internos, intenções, planos e crenças estabelecidos mentalmente, e também, relações entre objetos e sua significação no real e no imaginário que possibilitam que a relação adulto e criança, no jogo de faz-de- 
conta, siga além da interação estabelecida, transmitida e confrontada. É por esta via que podemos estabelecer uma possível relação entre a Teoria da Mente, as condutas discursivas e as condutas sociais sugerindo novos estudos e pesquisas, implicando a linguagem, a interação e a cognição. 


\section{BIBLIOGRAFIA}

ALBANO, E. (1987). "Emergindo da ilusão reducionista em psicolingüística". In: Cadernos de Estudos Lingüísticos. Campinas: IEL/Unicamp, nº 12. p:5-14.

(1987). "O psicolingüista convertido." In: Cadernos de Estudos Lingüísticos. Campinas: IEL/Unicamp, nº13. p: 41-48.

ARISTÓTELES. ( s/d) "Arte retórica e arte poética." Rio de Janeiro, Ediouro, Rhétorique. Paris: Les Belles Letres, 1967. Poétique. Paris, Les Belles Letres, 1979. p:2941 . (2000). A retórica das paixões. São Paulo: Martins Fontes. p:3-5.

ASTINGTON, J. W. (2003). "Dês pensées et dês choses." In: Comment les enfants découvrent la pensée. Paris: Retz. p:51-63.

BERTHOUD-PAPANDROPOULOU,I.; FAVRE,C. E VENEZIANO, E. (1990). "Constuction et reconstruction des conduites d"explication". In: CALaP.7/8, Paris: Universidade René Descartes. (trad. Guacira M. Machado, in; Fernandes,S.D. (org). (2003). “ Aquisição da Linguagem: conceito,definição e explicação na crianca. Araraquara: FCL/Lab. Editorial/ Unesp SP: Cultura Acadêmica Editora. P:39 a 68)

BITAR, M. L. (2002). Produção oral de crianças a partir da leitura de imagens. São Paulo: Humanitas/USP.

BOREL, M.-J. (1981). 'L'explication dans l'argumentation: approche sémiologique".in: Langue Française: argumentation et Enonciation., n.50, Paris: Larousse.

BRUNER, J. (2002). Atos de significação. Trad. Sandra Costa. $2^{\mathrm{a}}$ reimp, Porto Alegre: Artes Médicas. (1991) ." Le rôle de l'interaction de tutelle dans la résolution de problème". Le développment de l'enfant - Savoir faire, savoir dire. $3^{\mathrm{a}}$ ed., Paris:Presses de Universitaires de France. p:261-292.

CASTRO, M. F. P. de. (2003). Questões para as abordagens cognitivistas da argumentação e da comunicação em aquisição de linguagem.In: Saudades da Língua: a lingüitica e os 25 anos do Instituto de Estudos da Linguagem da Unicamp. Campinas: Mercado das Letras. P: 463-473 
(1996). Aprendendo a argumentar: um momento na construção da linguagem. 2a ed. rev., Campinas: Ed. da Unicamp.

CHALHUB, S. (2002.) A metalinguagem. 4a ed., São Paulo: Ática.

CHATEAU, J. (1987). O jogo e a criança. Trad.: Guido de Almeida. São Paulo: Summus.

COLTIER, D. (1986). “Approches du texte explicatif”, in: Pratiques. Paris n.51.p; $3-21$.

CORREA, L. M. S. (1999). Aquisição da linguagem: uma retrospectiva dos últimos trinta anos. Delta. São Paulo: Educ, v. 15. p: 339-383.

COSCIONE, J. F.(1988). "O jogo e os caminhos da descoberta", in Pré-Escola hoje: uma proposta pedagógica. São Paulo: SE/CENP.

DAVIS, M.; WALLBRIDGE, D. (1982).Limite e espaço: uma introdução à obra de D.W.Winnicott. Trad.: Eva Nick, Rio de Janeiro: Editora Imago.

DE LEMOS, CLÁUDIA T. G. (2003) “O erro como desafio empírico a abordagens cognitivistas do uso da linguagem: o caso da aquisição da linguagem”, In: Saudades da Língua: a lingüitica e os 25 anos do Instituto de Estudos da Linguagem da Unicamp. Campinas: Mercado das Letras. P: 515-524

(2002). "Das vicissitudes da fala da criança e de sua investigação”. In: Cadernos de Estudos Lingüísticos, n 47. Campinas:Unicamp · p.41- 69

DE LEMOS, C.T.G. (1982). "Sobre a aquisição de linguagem e seu dilema (pecado) original", In: ABRALIN-Boletim , nº 3. p: 97-126.

DUBOST, M. (1999)."Le développement des explications: émergence et signification de "parce que" dans 1 'interaction adulte - enfant". La Conversation:instrument, objet et source de connaissance. Paris: L'Harmattan. p:65-80.

DUCROT, O e ANSCOMBRE, J.C. (1988). L'argumentation dans la langue. $2^{\mathrm{a}}$ ed. Bruxelles: Mardaga.

FÁVERO, L.L. (2002).Coesão e coerência textuais. 9a ed., São Paulo: Ática.

FERNANDES, S. D. (org). (2003). Aquisição de linguagem: conceito, definição e explicação na criança. Araraquara: FCL/LE - UNESP; São Paulo: Cultura Acadêmica Editora.

FLAVELL, J.H.; MILLER, P.H.; MILLER, S.A. (1999) O desenvolvimento

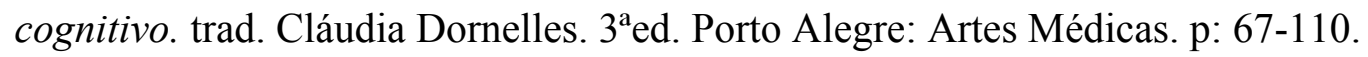


FRANÇOIS, F. (1996). Práticas do oral: diálogo, jogo e variações de sentido. Trad. de Lélia Erbolato Melo. São Paulo: Pró-Fono.

FRIEDMANN, A. (1996). Brincar: crescer e aprender - o resgate do jogo infantil. São Paulo: Moderna.

GALVÃO, I. (1995). Henry Wallon: uma concepção dialética do desenvolvimento infantil. 9a ed., Petrópolis:Vozes.

GRIZE, J. B. (1981). L'argumentation. Lyon: Presses Universitaires de Lyon. . (1990). Logique et langage. Paris, Ophrys. p 40-53.

HALTÉ, J. F. (1988). "Trois points de vue pour enseigner les discours explicatifs". Pratiques, n.58, Paris. p: 3-10.

GARDNER, H.(1994). A criança pré-escolar: como pensa e como a escola pode ensiná-la . trad. Carlos A. S. BN. Soares. Porto Alegre: Artes Médicas. p:25-35;52-75;8391.

HAUSENDORF, H.(1993). "L'étayage dans l'interaction", In: Aquisition et interaction em langue etrangère $\mathrm{n}^{\mathrm{o}} 2$. Paris: Ed. Encrages.

HUDELOT, C. (1997). "Modalités d'intervention de l'adulte dans la gestion d'un petit groupe d'enfants de moyenne section de maternelle en situation de description d'image". Cahiers d'aquisition et de pathologie du langage. $\mathrm{n}^{\mathrm{o}}$ : 14. Paris: Université René Descartes e CNRS.

. (1996). "Réactions au(x) textes de Bruner". Modelisation de $l^{\prime}$ apprentissage coopératif: l'étayage facteur de l'apprentissage. (mimeo).

. (1993). "Modalités de l'étayage langagier dans la restitution de récits de dix enfants présentant des difficultés de language". Le Récit Oral. Paris: Montpellier III. p:203-213.

HUDELOT, C. E VASSEUR, M.T. (1997). "Peut-on se passer de la notion d'étayage pour rendre compte de l'élaboration languagière em L1 \& L2?", In: CALAP n ${ }^{\circ} 15$, Paris:Université René Descartes.p:109-135.

HUDELOT, C.; PRÉNERON,C. SALAZAR-ORVIG, A. (2003). "Explicações, distância e interlocução na criança de dois a quatro anos", In: Aquisição de Linguagem: Conceito, definição e explicação na criança. (org. Silvia D. Fernandes), São Paulo: Cultura Acadêmica Editora. p: 69-84.

KISHIMOTO, T.M. (2003). O jogo e a educação infantil. São Paulo: Pioneira Thomson Learning. 
(org.). O brincar e suas teorias. São Paulo: Pioneira Thomson

Learning. (2002).

KOCH, I.G.V. (2003). A inter-ação pela linguagem. $8^{\mathrm{a}}$ ed., São Paulo: Contexto. . (2002). A coesão textual. 17a ed. São Paulo: Contexto.

LA TAILlE, Y. (org.) (1992.) Piaget, Vygotsky e Wallon: teorias psicogenéticas em discussão. Yves de La Taille, Marta Kohl de Oliveira e Heloysa Dantas. São Paulo: Summus.

LIER-DE VITTO, M.F. (1998). Os monólogos da criança: delírios da língua. São Paulo: Educ/Fapesp.

MELO, L.E. (2003) "Um gênero de discurso: a explicação", In: Aquisição de Linguagem: conceito, definição e explicação na criança. (org. Silvia D. Fernandes). São Paulo:Cultura Acadêmica Editora. p: 103-128. . (org.) (1999). Tópicos de psicolingüística aplicada. $2^{\mathrm{a} e d . ~ S a ̃ o ~ P a u l o: ~}$ Humanitas. $\left(1998^{a}\right)$. Formas de sustentação ou tutela dialógica "adulto-criança" em situação de narrativa. São Paulo: Linha d'água, no 13. p: 25-32.

.(1998b). "O papel da tutela na construção de narrativa por crianças".

São Paulo: Revista da ANPOLL, no . 4. p:111-119.

MOSCA, L.doL.S.(org.). (2001). Retóricas de ontem e de hoje. $2^{\mathrm{a}}$ ed., São Paulo: Humanitas Publicações/ FFLCH-USP.p: 17-54.

MOLLO, E. e BELLEVAL-BERTHOUX,A D'A. (1990). "Explication d"um jeu de société par de tout jeunes enfants". In: CALAP nº $7 / 8$ Paris: Universidade René Descartes. p:198-210.

PERELMAN, C. (1997) Retóricas. (Trad. port. Maria Ernestina G.G. Pereira). São Paulo: Martins Fontes. p: 57-91.

PERRONI, M. C. (1994). "Sobre o conceito de linguagem em aquisição da linguagem".In: Cadernos de Estudos Lingüísticos. Campinas: IEL/ Unicamp, no .26. p: 716.

PIAGET, J. (1999). A linguagem e o pensamento da criança. Trad. Manoel Campos, 7a ed. São Paulo: Martins Fontes. . (1982). Seis estudos de psicologia. (trad. M. Alice M. D' Amorim e Paulo S.L.Silva). $11^{\mathrm{a}}$ ed. Rio de Janeiro: Forense - Universitária. 
. (1978). A formação do símbolo na criança. Imitação, jogo e sonho, imagem e representação. (trad. A.Cabral e C.M. Oiticica). $3^{\text {a }}$ ed. Rio de Janeiro: Guanabara Koogan.

PIAGET, J. e INHELDER, B. (1995). Psicologia da criança. (Trad. Octavio Mendes Cajado). 14 ed. São Paulo: Bertrand Brasil. p: 46-79.

PIATELLI-PALMARINI (org). (1983). Teorias da linguagem, teorias da aprendizagem: o debate entre Jean Piaget e Noam Chomsky. (Trad. de Álvares Cabral). São Paulo: Cultrix/Edusp.

POSSENTI, S. (2003) . “Linguagem: Sistema de línguas” In: Saudades da Língua: a lingüítica e os 25 anos do Instituto de Estudos da Linguagem da Unicamp. Campinas: Mercado das Letras. p: 262- 368.

PRETI,D.;URBANO,H. (ORGS) (1990) . A linguagem falada culta na cidade de $S$. Paulo. São Paulo: T.A.Queiroz/Fapesp.vol.IV.p:7-10

PLANTIN,C. (1998). "Introdução: a argumentação entre enunciação e interação", In:Escritos 17/18, A argumentação. Revista do Centro de Ciências da Linguagem: Universidade Autônoma de Puebla. p:7-21.

VENEZIANO,E.;HUDELOT,C.(2002) “ Développement des competénces pragmatiques et théorie de l'esprit chez l"enfant : le cas de l"explication”. In: Bernicot ,J. et al. "pragmatique et Psychologie. Nancy: Presses Universitaries de Nancy. P: 215-236.

VERBA, M. (1990). "Construction et partage de significations dans les jeux de fiction entre enfants", In: Les jeux de fiction entre enfants de 3 ans. Paris:Presses Universitaires de France. p: 23-69.

(1999). "Les jeux symboliques de l'enfant avec le père et la mère: les dynamiques sociales et cognitives", In: La conversation: instrument, objet et source de connaissance. Paris: L"Harmattan.

VYGOTSKY, L.S. (1991). A formação social da mente. (Trad. José Cipolla Neto). $4^{\mathrm{a}}$ ed., São Paulo: Martins Fontes. p:119 -134.

WALlON, H. (1989).As origens do pensamento da criança. (Trad. Doris S. Pinheiro, Fernanda A. Braga). São Paulo: Manole.

WINNICOTT, D.W. (1975). O brincar e a realidade. (Trad. José O. de Aguiar e Vanede Nobre). Rio de Janeiro: Imago. 
ANEXOS 1 -Normas para Transcrição

\begin{tabular}{|c|c|c|}
\hline OCORRÊNCIAS & SINAIS & EXEMPLIFICAÇÃO* \\
\hline $\begin{array}{l}\text { Incompreensão de } \\
\text { palavras ou segmentos }\end{array}$ & ( ) & $\begin{array}{l}\text { do nível de renda...( ) } \\
\text { nível de renda nominal... }\end{array}$ \\
\hline Hipótese do que se ouviu & (hipótese) & $\begin{array}{l}\text { (estou) meio preocupado } \\
\text { (com o gravador) }\end{array}$ \\
\hline $\begin{array}{l}\text { Truncamento (havendo } \\
\text { homografia, usa-se } \\
\text { acento indicativo da } \\
\text { tônica e/ou timbre) }\end{array}$ & l & e comé/ e reinicia \\
\hline Entoação enfática & maiúscula & $\begin{array}{l}\text { porque as pessoas reTÊM } \\
\text { moeda }\end{array}$ \\
\hline $\begin{array}{l}\text { Prolongamento de vogal } \\
\text { e consoante (como s, r) }\end{array}$ & $\begin{array}{l}\quad:: \text { podendo } \\
\text { aumentar para :.:.: ou } \\
\text { mais }\end{array}$ & $\begin{array}{l}\text { ao emprestarem os... éh:.: } \\
\text {...o dinheiro }\end{array}$ \\
\hline Silabação & - & por motivo tran-sa-ção \\
\hline Interrogação & $?$ & $\begin{array}{l}\text { eo Banco... Central... } \\
\text { certo? }\end{array}$ \\
\hline Qualquer pausa & $\cdots$ & $\begin{array}{l}\text { são três motivos... ou três } \\
\text { razões... que fazem com } \\
\text { que se retenha moeda... } \\
\text { existe uma... retenção }\end{array}$ \\
\hline $\begin{array}{l}\text { Comentários descritivos } \\
\text { do transcritor }\end{array}$ & ((minúsculas) $)$ & $(($ tossiu $))$ \\
\hline $\begin{array}{l}\text { Comentários que } \\
\text { quebram a seqüência } \\
\text { temática da exposição; } \\
\text { desvio temático }\end{array}$ & ---- & $\begin{array}{l}\text {... a demanda de moeda -- } \\
\text { vamos dar essa notação - } \\
\text { - demanda de moeda por } \\
\text { motivo }\end{array}$ \\
\hline
\end{tabular}




\begin{tabular}{|c|c|c|}
\hline $\begin{array}{l}\text { Superposição, } \\
\text { simultaneidade de vozes }\end{array}$ & $\begin{array}{l}\text { \{ ligando as } \\
\text { linhas }\end{array}$ & $\begin{array}{l}\text { A. na }\{\text { casa da sua irmã } \\
\text { B. sexta-feira? } \\
\text { A. fizeram }\{\text { lá... } \\
\text { B. cozinharam } \\
\text { lá? }\end{array}$ \\
\hline $\begin{array}{l}\text { Indicação de que a fala } \\
\text { foi tomada ou } \\
\text { interrompida em } \\
\text { determinado ponto. Não } \\
\text { no seu início, por } \\
\text { exemplo. }\end{array}$ & $(\ldots)$ & $\begin{array}{l}\text { (...) nós vimos que } \\
\text { existem... }\end{array}$ \\
\hline $\begin{array}{l}\text { Citações literais ou } \\
\text { leituras de textos, } \\
\text { durante a gravação }\end{array}$ & " " & $\begin{array}{l}\text { Pedro Lima... ah escreve } \\
\text { na ocasião... "O cinema } \\
\text { falado em língua } \\
\text { estrangeira não precisa } \\
\text { de nenhuma baRREIra } \\
\text { entre nós"... }\end{array}$ \\
\hline
\end{tabular}

- $\quad$ Exemplos retirados dos inquéritos NURC/SP No. 338 EF e $331 D^{2}$.

\section{Observações:}

1. Iniciais maiúsculas: só para nomes próprios ou para siglas (USP etc.)

2. Fáticos: ah, éh, eh, ahn, ehn, uhn, tá (não por está: tá? você está brava?)

3. Nomes de obras ou nomes comuns estrangeiros são grifados.

4. Números: por extenso.

5. Não se indica o ponto de exclamação (frase exclamativa).

6. Não se anota o cadenciamento da frase.

7. Podem-se combinar sinais. Por exemplo: oh::.... (alongamento e pausa).

8. Não se utilizam sinais de pausa, típicos da língua escrita, como ponto-evírgula, ponto final, dois pontos, vírgula. As reticências marcam qualquer tipo de pausa, conforme referido na Introdução.

Preti, Dino; Urbano,Hudnilson (orgs). A Linguagem Falada Culta na Cidade de São Paulo. São Paulo: T.A.Queiroz/Fapesp, 1990, p:7-8. 


\section{ANEXOS II - CORPORA}

\section{Episódios: criança B}

\section{Episódio praia}

89-B: deixa assim........por onde que vai até a praia?... ((olha $\mathrm{A}))$ que tal ir até lá na porta?

90-A: (( olha B, sim com a cabeça)) vamos ... é a estrada da praia?

91-B: tá... ah:.: (( empurrando o carro, desencaixou o carro e o castelo e ela encaixa novamente e tira pra fora do tapete, empurra o carro por um espaço longo))

92-A: nossa que estrada longa hein?

93-B: ((

94-A: já está voltando?

95-B: já... e agora vai ser um caminho mais longo ainda

96-A: nossa assim eles vão ficar muito cansados

97-B: e é a Emília que tá dirigindo (( certo momento ela pára o castelo))

98-A: aí eles chegam?

99-B: eles chegam .. deixam o castelo aqui... e vão pra (estrada) bem longa

100-A: aí o castelo fica aqui?

101-B: uh uh porque .. a Emília já tá dormindo

102-A: mas ela tá dirigindo... ela não pode dormir dirigindo

103-B: mas ela já tá dormindo

104-A: então é o Visconde que tem que dirigir

105-B: mas o Visconde também está dormindo

106-A: mas como pode dirigir dormindo?

107-B: é que ele tem o periquito dele e o periquito que tá dirigindo

108-A: e onde tá esse periquito?

109-B: ah... (( expressão pensativa, olha A )) ele chamava guaxinim

110-A: o periquito chamava guaxinim?

111-B: é

112-A: tá e cadê ele?

113-B: é que ele tá escondido embaixo do carro ((olha A))

114-A:coitado do periquito.. embaixo do carro?

116-B: ((risadas, olha A))

117-A:e ele que tá dirigindo?

118-B: $e^{\prime}$

119-A: aqui que fica o periquito? ((aponta))

120-B: ((olha o lugar apontado)) é ((olha para A))

121-A: e ele tá dirigindo o carro... tá bom... (...) 


\section{Episódios: criança G}

\section{Episódio prédio}

1-G: (( pega os blocos e faz encaixes, montando duas peças e colocando-as uma do lado da outra, fala que uma é casinha e a outra, um pássaro, apontando cada uma, respectivamente)).

2-A: cadê seu pássaro que eu não tô vendo?

3-G: ((aponta o pássaro ))

4-A: ah.. esse é seu pássaro ....certo...que mais você montou?

5-G: uma casinha (( aponta a peça que ele chamou e casa))

6-A: uma casinha..deixa eu ver a sua casinha?... isso... então tem uma casinha e um pássaro ....ótimo...o que mais a gente pode montar?

7-G: ((fica mexendo nos blocos)) eu já sei...um prédio

8-A: prédio?

9-G: ((faz os encaixes em silêncio,termina, olha para A))

10-A: esse é seu prédio?

11-G: $a h n . . a h n$

12-A: Olha:::.....então você montou mais uma coisa...olha só que legal...hein? eu vou montar uma coisa também posso?

13-G: pode

14-A: ((expressão facial pensativa)) o que eu posso estar montando ((faz encaixes com os blocos))

15-G:uma casa...um pássaro...um castelo (( olhando para as peças montadas por ele))

16-A: mas isso é um castelo ou um prédio? (( aponta a peça ))

17-G: é prédio

18-A: ahn? ... mas você chamou de castelo

19-G: eu sei mas parece com um castelo

20-A: parece com um castelo né ...tá certo....

\section{Episódio carrinho}

24- A: e aí você está fazendo outra coisa agora?

25- G: é um carrinho

26- A: um carrinho...esse é um carrinho?

26- G: hun..hun (( sinal de sim com a cabeça, empurra o carrinho pelo chão, mostrando ))

28-A:é

28- G: hun...hun.. ah..pode por um negocinho embaixo para não cair ((coloca uma peça quadrada para manter o carrinho sem cair pois está só com duas rodas))

30- A: mas é um carrinho meio estranho você não acha? ...um carrinho não pode cair

31- G: eu sei mas... porque a rodinha escorrega

32-A: a rodinha escorrega e então ele cai?

33-G: mas agora ele não cai ((mostra para A o carrinho apoiado em um bloco quadrado))

34-A: mas não tem um jeito de fazer ele não cair?

35- G: já sei 
36-A: como?

37-G: com isso atrás ((coloca de novo o bloco quadrado para o carrinho se apoiar))

38-A: ah... mas sem ter isso ... tem que ser um coisa que ele tem que faz ele ficar de pé

39-G: ((fica mexendo no carrinho))

40-A: vem cá ....quantas rodas tem esse carro?

41-G: ((olha para A)) duas

42-A: e quantas rodas tem o carro?

43-G: na frente?

44-A: o carro do seu pai .... ele tem ...

45-G: duas e duas na frente ((mostra com as peças de rodinha a posição da rodas))

46-A: então... não está estranho esse carrinho?

47-G: hun... hun (( pega outras duas rodas e tenta encaixar))

48-A: não tá faltando alguma coisa?...você não acha?

49-G: ((fica tentando encaixar as rodas ))

50-A: porque se só tem duas rodas então é uma bicicleta

51-G: ((silêncio, continua atento na montagem))

52-A: ou não é?

53-G: unh... não é pa/ para fazê / isso ái ((troca de peça e tenta encaixar outra))

54-A: qual a diferença de carro e bicicleta você sabe?

55-G: sei tem...tem... uma na frente... duas aqui ((mostra a posição das rodas na peça))

56-A: sei isso é uma...

57-G: bicicleta ((olha para A))

58-A: bicicleta... e o carro?

59-G: carro tem duas rodas na frente duas rodas atrás ((mostrando a posição na peça))

60-A: o que você fez é um carro ou uma bicicleta?

61-G: carro

62-A: então TÁ meio estranho porque...

63-G: agora ele não cai porque está encima do meu pé ((aponta ))

64-A: tá ...então esse aí é um carro

65-G: porque carro tem duas rodas e duas na frente

66-A: tá então isso aí é um carro porque tem duas rodas na frente ?

67-G: não tem duas rodas atrás

68-A: rodas atrás então é um carro?

69-G: tá faltando roda aqui

70-A: tá faltando o que?

71-G: ((pega duas rodas e tenta encaixar atrás))

72-A: mas não tá entrando?

73-G: tem que ser maior

74-A: ah... tem que ser maior?

75-G: tem que ser desta aqui oh ((pega outra peça montada e aponta o bloco que quer para o encaixe)) 
76-A: e não tem maior? ((procura entre os blocos no chão ))

77-G: não (( olha para A))

78-A: ah.... então desmonta do meu pássaro ...pode tirar do meu pássaro

79-G: ((tira o bloco desejado e tenta encaixar as rodas))

80-A: agora será que dá para fazer teu carro?

81-G: hun... hun ((tenta o encaixe))

82-A: agora você fez um ... \{carro

83-G: $\quad$ \{carro

84-A: ah... agora é um carro ...porque é um carro?

85-G porque tem duas rodas atrás e duas rodas na frente

86-A: ah... e é diferente de bicicleta

87-G: uhn...uhn... ( eu não estava conseguindo encaixar as rodas)

88-A: ah...legal...e para isso você teve que pegar uma coisa grande...uma peça grande

89-G: isso

\section{Episódio montagens diversas}

90-A: jóia......então vamos ver tudo o que você montou...você montou um prédio ((aponta uma peça))

91-G: prédio ...esse é o castelo ...esse é o carro ((aponta a peça certa))

92-A: tá... porque ESsa é a casinha?

93-G: eu falei pássaro ((pega a peça))

94-A: não... ESse ((aponta a peça referida))

95-G: porque casinha é assim

96-A: e porque a casinha é assim?

97-G: porque casinha tem um telhado assim

98-A: e porque aquele é um pássaro?

99-G: porque tem uma cabeça um nariz uma boca e depois tem um pé ...e uma asa...TEm ... asa

100-A: certo

\section{Episódio casa da bruxa}

209-A: é...e a bruxa ... vamu/ fazê / a casinha dela?

210-G: ( ) ((pega uns blocos começa a montar))

211-A: uh.. a gente pode fazer essa casinha sê/ a caverna dela (( mostra a casinha))

212-G: ((olha )) pode sêl (( continua montando,mostra ao terminar))

213-A: tá .. você montou a caverna dela

214-G: a cadeira dela pode assim óh

215-A: ah.... a caDEira ...ela tem uma cadeira?

216-G: a cadeira (fica) aqui...

217-A: ahn.. mas ela não tem um caldeirão?

218-G: tem... o caldeirão pode ser ... esse aqui .... perto dela (( olha A e mostra)) 


\section{Episódios: criança J}

\section{Episódio carro}

1-A: você sabe montá/ um caRRInho?

2-J: ((

3-A: então a gente pode montá/ um carrinho.... e põe ELES no carrinho

4-J: (( sim com a cabeça,olha a câmera e tenta fazer uns encaixes ))

5-A: pode pô / ? ...pode fazer o carrinho? ... COmo que cê/ faz o carrinho?

6-J: ((olha para A com cara de quem duvida de A ))

7- A: você faz o carrinho difeRENte do meu

8-J: como que é o seu?

9-A:então eu POsso fazer o meu?

10-J: eu vou fazê/ o MEU::

11-A: então faz o seu carrinho ......eu vou fazer meu carrinho

(( ambas fazem seus encaixes e montam seus carrinhos em silêncio))

12-J: ((encaixa o Visconde em seu carrinho))

13-A: você vai fazer o carrinho do Visconde?

14-J: ahn:::n (( empurra o carrinho dela))

15-A: ah... eu tô/ fazendo o carrinho da Emília ((encaixa a Emília e empurra o carrinho igual faz J, até que batem os carrinhos))

16- J: $\{a n h . . .(($ cai as rodas $))$ é o MEu (( pega o bloco que desmontou $))$

17-A: \{anh ...é o seu ... o seu caiu a roda

18-J: (( pega e encaixa novamente))

(( voltam a empurrar os carrinhos e A dá um impulso e solta seu carrinho em direção a J))

19-J: (( pega o carrinho de A)) o seu é maior

20-A: porque?

21-J: porque o seu é maiOR

22-A: tá/ VENdo .... o carrinho meu ...é diferente do seu carrinho

23-J: que é ? (( mexendo nos blocos))

24-A: não É? é::.... o meu caRRInho é difeRENte do Seu...carrinho

25-J: óh..... o que eu fiz (( coloca outros blocos no seu carrinho e mostra))

(( voltam a empurrar seus carrinhos e $\mathrm{J}$ faz mais força e os carrinhos se batem mais forte))

26-J: $\{(($ risada $))$

27-A: \{ óh ...ishi:.:i ... o meu carrinho quebrou... agora... também as rodas (( encaixa seus blocos))

28-J: o meu tál as rodas ( ) ....

\section{Episódio trem}

28-J: (...) .... dá pra fazer asSIM..... óh

29-A: fazer o quê ? 
30-J: PÉral ( ) empresta o seu ? (( pega de A, encaixa um carrinho no outro e empurra pelo chão))

31-A: ahn.....ah:::.: entenDI::.:.... um carrinho puxa o outro

32-J: NÃO ... parece um TREM

33-A: parece um trem ((fica empurrando o carrinho pelo chão))

34-J: é só encaixál aQUI...Óh/.... só faze/ asSIM

35-A: e aí... parece um trem::...é :::

36-J: se tivesse mais duas rodinhas::::

37-A: é... a gente fazia mais um trem

38-J: uma pá/ aQUI né?

39- A: é... não tem mais roda nesse

\section{Episódio cozinha}

135-A: não... então pérai/... a cozinha tem o quê?

136-J: a minha cozinha?

137-A: (( sim com a cabeça))

138-J: tem mesa (( olha A))

139- A: que mais?

140-J: a minha MEsa é asSIM ... ela é grudada.... e ela a::bre e fe::cha...aQUI... ela tá fechada... e aQUI... ela tá aberta... aqui ela tá fecha::da ... e aqui ela tá abe:::rta (( gestos para mostrar ))

141-A: tá ...então ela tem uma\{ME:::sa

142-J:

$$
\{\text { tem.....tem duas geladeiras ..... tem armário grã:.:.:.nde }
$$

\section{Episódio mesa}

164-J: não.... a mesa é es: :.:sa (( mostra a peça))

165- A: essa é a MEsa?

166-J: é... pode ser... porque mesa é asSIM

167-A: mas você disse que a mesa é de abrir e feCHAR

168-J: ((silêncio, amarra o tênis)) seRÁ que ela vai feCHA/?.. aBRI/ ...e feCHA/?... NÃO.....eu tive uma idÉE::ia ((olha A))

169-A: o que cê/ teve de idéia?

170-J: (( volta a amarrar o tênis)) ah não.... mas não é:......... não fecha tem ( ) ... ah ((termina de amarrar o tênis))

171-A: o que que foi?

172-J: mas a mesa pode sê/... sem abri e fechá/ (( olha para A))

173-A: tá bom ...pode ser sem \{abri/ e fechá/

174- J:

\{na casa do meu PAi...na casa do meu pai lá tem uma ... uma mesa na salinha...

num abre e fecha

175-A: não? 
176-J: não preci::sa né?

177-A: tá bom.. não precisa ... LÁ na vó ...a mesa também não abre e fe::cha.. né?

\section{Episódio de idéias e encadeamentos de eventos : tema história vida cotidiana}

180-J: vamu/ brincá com a CAsa

181-A: com a CAsa?

182-J: (( silêncio , encaixa alguns blocos)) pode começá/?

183-A: pode...pode começál

184-J: vishi... faltou as portas do quarto

185-A: aí .... hum:........ agora ... faz de conta

186-J: tá bom... tá bom

187-A: que qui você vai fazê /?

188-J: fingi que eles tavam dormindo

189-A: quem que acorda priMEiro?

190-J: EU primeiro

191-A: você?... voCÊ que acorda primeiro?

192-J: ãhn ãhn .... enTÃO fica quieta senão eu vou acordá / ((com mudança de voz ))

193-A: tá bom

194-J: esPEra ... acordei ... desci a escada e acordei você (( com voz natural, movimenta o boneco conforme fala )) -- ai você...oi: :.: aCORda-- ((com mudança de voz ))

195-A: você tá me acorDANdo agora? ((com mudança de voz ))

196-J: é tá na hora de nós saí/ ((com mudança de voz ))

197-A: imagina eu quero dormir mais ((com mudança de voz ))

198-J: então tá bom::: ((com mudança de voz ))

199-A: cê vai aonde ((com mudança de voz))

200- J: eu vô / saí com meus amigos ((com mudança de voz ))

201-A: eu vô / ficá/ dormindo ((com mudança de voz ))

202- J: enTÃO eu vou falar prá eles TÁ?.... ((com mudança de voz )) ((olha para A)) cadê.? ((com voz natural))

203-A: o quê? ((com voz natural))

204- J: cumelé cumelé

205-A: vai tê / que fazê/ de conta

206-J: tá bem.... ((voz mudada volta com o boneco, J sobe com o boneco as escadas)) oi não vai sai lá fora com a GENte? ((com mudança de voz ))

207-A: ((observa)) eu..aí qu/eu tô/ cum preGUIça ((com mudança de voz))

208-J: acorda lo::go... troca de roupa ...vai tomál café ((com mudança de voz ))

209-A: aí..tá bom ((com mudança de voz ))

210-J: então VEM ((com mudança de voz ))

211- A: ((A faz-de-conta que está acordando, trocando de roupa, J faz-de-conta que toma café))

212-J: vem tomá café \{aGOra ((com mudança de voz )) 
213-A: $\quad$ \{ e aí você tem.. que é ....onde que toma café ? (( com mudança de voz ))

214-J: na mEeesa ((com mudança de voz))

215-A: cadê a \{mesa ? (( com voz natural))

216-J: $\quad$ quê você QUÉ ?.... ((com mudança de voz )) \{aQUI a mesa ((com voz natural sussurrada ))

217-A: \{essa é a mesa? ((com voz natural ))

218-J: (( sim com a cabeça)) qui você ...quél ...pá/ tomá/ café ?

219-A: ((senta o boneco na mesa))

220-J: o que você quél pál tomá/ café?

221-A: e esse? ((com mudança de voz ))

222-J: você faz o ...-- esse é o fogão ...- - ((com mudança de voz ))

223-A: esse é o fogão e essa é a mesa? ((com voz natural))

224-J: essa é a mesa ...agora você pega o que você qué/ ((com mudança de voz ))

225-A: tá ((com mudança de voz ))

226-J: finge que aqui é minha (geladeira)

227-A: eu vou pegar o le::ite (( faz barulho de pegar e de por leite)) ((tz))...vou pegá/ a manteiga (( barulho)) $((\mathrm{tz}))$... vou pegar geléia $((\mathrm{tz}))(($ faz barulho $))$

228-J: \{pão

229-A: \{e você? ... anh?...o pão não está na geladeira ((com mudança de voz ))

230-J: oh ... ãnh?... guarda... aqui ....((gestos, com mudança de voz ))

231-A: tá bom ((tz)) ((com mudança de voz ))

232-J: pode tomá/ café ((com mudança de voz ))

233-A: cê não vai tomar café coMIgo?... cê não vai comê/ pão coMIgo? ((com mudança de voz))

234-J: eu já coMI .....eu acordei priMEIro que você ((com mudança de voz ))

235-A: ah:: é verdade....(( mexe o boneco)) pronto... eu JÁ tomei café((com mudança de voz ))

236-J: vamu/ sai ago::ra? ((com mudança de voz, movimenta o boneco))

237-A: vamus::: e vamu/ deixar TUdo bagunçado na mesa ?((voz mudada))

238-J: então arRU::ma

238-A: ah ...então aJU::da

240-J: (( faz movimentos com o boneco)) agora vamu/ pô/ a toalha? ((com mudança de voz ))

241-A: ((faz movimentos com o boneco)) pronto .... vamus:.: ((com mudança de voz ))

242-J: agora vamu/saí/? ((com mudança de voz))

243-A: aonde nós vamus::::? ((com mudança de voz ))

244-J: lá pra FO::::ra

245-A: \{aonde?

246-J: \{quer assisti.. um pouco de tevê.:.:?? ((com mudança de voz ))

247-A: quero ((com mudança de voz ))

248-J: então vamus:: ((com mudança de voz))

249-A: o que a gente vai querê/ assistí/ hein? ((com mudança de voz ))

250-J: você que sá::.bi ((com mudança de voz ))

251-A: añh:::::: eu quero assistí/:::::: ((com mudança de voz )) 
252-J: vamu/pensá/ ((com mudança de voz ))

253-A: VAmu/ ... o que você gosta? ((com mudança de voz ))

254-J: eu go:..s::to ...gosto ....do... teletabis:.... (( olha A)) (( com voz natural))

255-A: você gosta do teleTAbis? ((com mudança de voz ))

256--J: eu também gosto ((com mudança de voz ))

257-A: ah..então... \{vamu/ assisTIR

258--J: $\quad$ eu também .... gosto de verdade (( com voz natural, olha A))

259-A: ah de verdade... de verDAde? \{você gosta de mentira e de verDAde (( com voz natural))

260--J: $\quad$ [agora ... vamu/ assisti/? ((com mudança de voz )) -- agora vamu/

pegál e...tz tz tz-- ((com voz natural, anda com os bonecos e posiciona todos na frente da televisão)) asSIM (

) -- ...vamu/ assisTí/? ((com mudança de voz ))

261-A: (( coloca o seu boneco junto))

((silêncio os bonecos ficam um tempo na frente da tv e A e J observam))

262-J: ishi... já acabou ((com mudança de voz ))

263-A: já acabo:::u? ((com mudança de voz ))

264-J: vamu/ lá fora cum/nosso aMIgo?(( com mudança de voz ))

265-A: tá bom ((com mudança de voz ))

((levam os bonecos para outro espaço))

266-J: oi::: ((com outra mudança de voz, $2^{\mathrm{a}}$ voz diferente $\left.)\right)$

267-A: cadê o nosso amigo? ((com mudança de voz, movimento de procurar ))

268-J: num sei (( com voz natural ))

269-A: (( pega um bloco e coloca de pé ao lado dela))

270-J: oi:: ((com mudança de voz ))

271-A: oi::: ((com outra mudança de voz , 2 $2^{\mathrm{a}}$ voz diferente $)$ )

272-J: cadê a Karol? ((com mudança de voz ))

273-A: oi? ((com outra mudança de voz, $2^{\mathrm{a}}$ voz diferente $)$ )

274--J: cadê a KaROL... ouve ...alô

275-A: ((pega o boneco)) eu não sei onde tá a Karol ...TÁ? ((com outra mudança de voz 2 ${ }^{\mathrm{a}}$ voz diferente))

276-J: onde?

277-A:eu não sei eu...eu...não VI a Karol (( com outra mudança de voz. $2^{\mathrm{a}}$ voz diferente))

278-J: já sei TÁ ... seu pateta ((com mudança de voz))

279-J: (( volta para casa , coloca um bloco )) oi Karol...acorda ((com mudança de voz))

280-A: ((observa))

281-J: você é ela...é..... ((com voz natural))

282-A: (( mexe com o bloco)) annhhhnnnn ((bocejando))

283-J: alô....onde você TAva.?...eu não sei onde ir..... eu TAva te procuRANdo... lá ((com mudança de voz ))

384-A: eu tava andando de bicicleta LÁ na rua ((com $3^{\mathrm{a}}$ mudança de voz ))

285-J: e você ? ((com mudança de voz, se dirigindo a outro bloco))

286-J: eu tava tomando café ....assistindo t.v.....né:.:.:amigo ? ((com mudança de voz, $2^{\mathrm{a}}$ voz diferente)) 
287-A: é verdade.... vocês não querem brincar lá na minha casa? (( com mudança de voz, $1^{\mathrm{a}}$ voz diferente))

288-J: NÃo .. vamu/ brinca lá FOra ....esqueceu ? ((com mudança de voz, 1ªvoz))

289-A: é que eu tô/ com preguiça ...tá ...muito frio ((com mudança de voz, $1^{\mathrm{a}}$ voz ))

290-J: então vamu/ por um caSAco? ((com mudança de voz, $1^{\mathrm{a}}$ voz ))

291-A: então vamu/ ((com mudança de voz, $1^{\mathrm{a}}$ voz $\left.)\right)$

((movimentam os bonecos em direção á casa, inclusive os bonecos blocos))

292-J: tem que pegar esse (( com voz natural))

293-A: esse aqui junto? ((com voz natural))

294-J: não.. casa..... a casa deles ..são aqui ((com voz natural, aponta e mostra))

295-A: tá....e esses vão pegar o casaco? ((com voz natural))...vão LÁ na minha casa pega o casaco? ((com mudança de voz ,sobe a escada))

296-J: ah esqueci ...minha casa não é aqui ((com mudança de voz, move o boneco em outro canto ))

297-A: ele já pôs o casaco (( fazendo movimento de quem já se vestiu e onomatopéia))

298-J: vão fingí / que eles... iam dormí/ ((com voz natural)) ...se tá com preguiça? ((com mudança de voz ))

299-A: ah eu tô com preguiça ...((sorri)) eu vou fingí/ que tá dormindo ((com mudança de voz ))

((colocam os bonecos deitados na cama $))$

300-J: $\dot{e}$

301-A: e agora... acabou? (( com voz natural))

302-J: deixa eles dorMINdo

303-A: tá bom......então deixa eles dormindo

\section{Episódios : Criança L}

\section{Episódio jogo de adivinhação}

1-A: o que você vai montar?

2-L: montá/ não...jogá/

3-A: então.... se...\{ jogar

4-L: $\quad\{$ um $\{$ jogo...

5-A: $\quad\{$ vamu/ $\{$ brinca

6-L: $\quad$ que eu conheço?

7-A: que jogo que é?

8-L: de:......u/ jogo de adivinhação

9-A: tá ...um jogo de adivinhação

10-L: é::assim ...eu tenho que imitá/ um bicho pá / ocê acertá/

11-A: tá

12-L: vamu/vê (( ele imita um bicho ))

13-A: ah.. é um leão

14-L: acertou ....agora é a vez de você

15-A: acertei ..... minha vez?

16-L: é

17-A: eu vô/ tê/ que imitá/ um BIcho? 
18-L: $e$

19-A: ahn:::.:...... ((faz um gesto imitando um bicho))

20-L: elefante

21-A: ah::::: assim não VAle

22-L: é fácil...... ocê/ vê/ quoi eu vô / imitá/ ....(( começa a pular com um perna só)) adivinha?

23-A: eu já sei...... saci pererê... saci pererê

24-L: é ... acertou

25-A: com uma perna só ......só podia ser

26-L: vai...você

27-A: eu vou....ahn:::: (( pega os blocos e começa a fazer encaixes))

28-L: OPS... ...mas o que você tá fazendo?

29-A: cAlma.... VOcê tem que descobrir... NÃo vou falar não

30-L: tem que IMITÁ/ o bicho

31-A: não...mas eu vou monTÁ/ ele aqui porque eu mão sei IMITÁ/ esse bicho

32-L: qual que é

33-A: você vai ver:::

34-L: ah .. é uma cobra

35-A: como você sabe?

36-L: cobra não fica no chão?

37-A: fica... \{mas::::

38-L: $\quad\{$ então ... $(($ risada $)) \ldots s \hat{o} / e u$

39-A: mas ahn::.:.:.:.:.: ((desmonta os encaixes)) você

40-L: (( começa a imitar, pulando pela sala))

41-A: CANguru

42-L: não (( continua pulando))

43-A: ãh::.:.:.: COElho

44-L: ele pula por duas pernas

45-A: por duas penas.....SApo

46-L: é fácil...fácil

47-A: (( pega os encaixes e começa a montar))

48-L: porque você não \{faz imitando aí?

49- A: $\quad\{$ eu ....u.:.:.:.:::(( onomatopéia $))$

50-L: já sei... cascavel

51-A: tz:::::: (( não com a cabeça))

52-L: elefante

53-A: tz::::: (( não com a cabeça))

54-L: não tem.. como saber

55-A: (( acrescenta outros encaixes, termina e faz o bicho andar))

56-L: um DInossauro

57-A: ah .. acertou 
58-L: deixo/vê/ .... deixo/ vê/:.......... deixo/vê/.:...

59-A: e se você usar as peças... será que você faz? (( desmonta seu encaixe anterior))

60-L: não

61-A: você não tentou

62-L: tô/ pensando ...já sei ... vou monTÁ/ um negócio (( pega os blocos))

63-A: você vai montá/ ou vai IMItá/

64-L: imitá/ ...vai ...(( larga os blocos e começa a pular))

65-A: faz mais um pouco para eu ver

66-L: (( pula mais um pouco)) mora LÁ na lagoa... o que qui é ? (( se joga e pula ))

67-A: mora LÁ na lagoa ..que eu saiba... é o SApo

68-L: quer que eu fale?

69-A: quero

70-L: u/ jacaré

71-A: ah ... mas o jacaRÉ não FAZ tudo isso

72-L: um jacaré pegandu/ co MIda qui eu falo

73-A: ah::::: ((faz outro encaixe)) i::::sso é um jacaRÉ oh....vamos ver se você descobre o que eu vou montá/ ?

74-L: acho que eu já sei de eu vêl

75-A: (( continua com os encaixes $))$

76-L: um BARco?

77-A: não

78-L: um NAvio?

79-A: não

80-L: um PRÉdio?

81-A: não?

82-L: ah..... EU e VOCÊ?

83-A: não

84-L: (( observa)) bem ... deixo/ vê/ ( ) (( pega as peças e coloca em outro lugar ))

85-A: não... eles TEM que ficar aqui... sepaRAdos ......senNÃO... não vai adivinhar ((coloca novamente as peças no lugar de onde ele tirou))

86-L: um PRÉdio

87-A: Não (( continua montando ))

88-L: ah...já sei

89-A: o que?

90-L: uma estacioná/ de carro?

91-A: não (( continua montando encaixes))

92-L: uma CAsa de saci pererê?

93-A: não (( movimenta as peças $))$

94-L: (( observa)) um TÁxi?

95-A: (( continua movendo suas peças montadas)) 
96-L: GAsolina

97- A: ah::.... acerto:::u::.....um posto de gasolina ((desmonta as peças))

98-L: (( sorri))

99-A: agora você?

100-L:vou montá/ o que você fez

101-A: você vai montá/ o que?

102-L: o que você fez (( monta uma peça))

103-A: tá ((observa)) ah... isso é a bomba de gasolina

104-L: não

105-A: mas eu tinha feito asSIM.....era a MInha bomba de gasolina

106-L: mas não é

107-A: já não é mais ?

108-L: não...não é

109-A: então o que que é

110-L: espera... adiVinha

111-A: ((observa)) o que qui é isso?

112-L: espera........ \{ eu não posso falar

113-A: $\quad$ isso é um CArro?

114-L: mas não é um carro comum não

116-A: tá não é um carro comum não

117- L: não.... adiVInha ... tem que adiviNHÁ/... quando eu acaBÁ/ de monTÁ/... acho... vamu/vê/ se você adivinha?

118- A: tá bom ....então vou esperá/ você terminá/ de montá/

119- L: (( continua montando)) epa bz:..... ( ) míssel ((onomatopéia de explosão))

120-A: ((observa)) que:: ? ....você fez uma bomba?

121-L: uma guerra

122-A: uma GUERra ...meu DEUS:......lançou um míssel e estourou com TUdo?... ah ... eu vou montá/ uma coisa para você adivinhá/

123-L: é Casa?... um AVIão?

124-A: NÃo .... deixo/ eu terminá/ rapaz:.:.... CREdo...você tem que ir com CALma

125 L: ah... uma PONte.....uma PONte

126-A: (( silêncio, termina a montagem)) acertou ...é uma ponte... (( mostra a ponte))

agora você (( desmonta seu encaixe))

127-L: (( pensativo, mexe nos blocos $))$ deixo/vê/ ......xô/vê/.....:não é uma cobra

128-A: \{tá/ bom

129-L: \{ é outro tipo de cobra

130-A: tá/ bom eu vou esperá/ você terminá/ de montá /

131-L: (( termina movimenta a peça )) ((onomatopéia)) sizz:.:.:siz:.:.

132-A: parece cascavel

133-L: não é cascavel .... viz:...:viz:... 
134- A: então é uma SUcuRI

135- L: sucuRI::?

136-A: sucuri

138-L: nunca vi esse.: ...tipo de cobra

139-A: ah... então não sei que tipo de cobra que é

140-L: é:..........é uh:.... ((pensa)) quer dizer...é um...S.:.Apo de cobra

141-A: ah... isto é uma coisa que você inventou da SUa cabeça... não sei NÃo.... não existe

$142 \mathrm{~L}$ : não... que eu vi no sapo ZAp

143-A: ahn?

144- L: é um sapo... que antes do sapo... no ovo... ele virou uma cobra

145-A: entendi... entendi... tá então eu vou montá/ dentro de uma casa... deixô/ vê/ se eu consigo

146- L: tá e o que montou deixa aqui ó....pa/minha mãe vêl

147-A: tá (( encaixa novos blocos))

148-L: um rato?

149-A: não

150-L: ((observa)) um macaco

151-A: (( silêncio)) esse aqui é o fogão... agora eu vo/ montá/:::::.::

\section{Episódio televisão de raio}

172-L: ( ) televisão

173-A: essa é uma televisão? como que é isso?

174--L: televisão de raio

175-A: de raio?.. que qui é isso?

176-L: já viu raio?

177-A:JÁ

178-L: então é uma televisão de raio....aí...no buraco

179-A: e como é televisão de raio ...eu nunca vi televisão de raio

180-L: é de outro país essa televisão

181-A: ah:::: de outro país essa televisão

182-L: é ... é ..... a lá... e tem que ficar mu:..:ito longe dela ...senão...:

183-A: e como funciona essa televisão?

184-L: de raio ... com raio

185-A: então... com que eu ligo?... e se cai um raio?

186-L: cai o raio aqui óh (( mostra o lugar))

187-A: e aí ela só liga quando tem raio?

188-L: é...é

189-A: e quando não tem raio... a televisão não liga?

190-L: só:.....se..... colocar água ..ela liga.

191-A:ah tá/... porque senão o dia que não tem raio \{ela não vai ligar 
193-A: ah ..tem que ser água quente?

194-L: é água quente

195-A: e porque tem que ser água quente?

196-L: uh... ...uma coisa eu não... nunca vi essa televisão um dia... mas eu .... só vi na minha televisão 197-A: você viu essa televisão na televisão?

198-L: é mas eu não entendi .... que ela é dos chineses.....

199-A: ah.... ela é dos chineses... tá/ certo... eu nunca vi essa televisão e nem na televisão

200-L: é ... e tem essa CApa para proteger.... quando tá chovendo água fria então tem que co.....apertál aqui e ai a capa .... perail/ (( encaixa um novo bloco))

201-A: o que acontece com a capa?

202-L: espera ... tô/ montando aqui ((encaixa a capa))........aí a capa tá aqui ... aperta o botão e ela se levanta e vai aqui

203-A: aí ela cobre

204- L: $\dot{e}$

205-A: isso se chover água FRIa?

206-L: $\dot{e}$

207-A: e se chover Água QUENte?

208-L: (( silêncio pensativo))

209-A: aí ela fica lá embaixo? (( aponta abaixo da televisão))

210-L: é

211-A: mas você já viu chover água quente?...eu só vi chover água FRIa

212-L : ((olha para A)) ..não.. mas é de outro paÍS... eu já falei que essa televisão é de outro paÍS... eu não falei?

213-A: é dos chine:::ses é verdade ....é dos chineses... você falou... é verdade

\section{Episódios: criança JP}

\section{Episódio idéias e encadeamento de eventos história imaginada com personagens Emília e Visconde}

128-JP: ((começa a fazer o ataque) $)$ \{ tsssss tffffff brummm (( onomatopéia de tiro)) ((bate na máquina e dá risada ))

129-A:

\{ escudo...escudo ... escudo...... ..nossa furô / o escudo protetor ... arrebentou a::: .. meu Deus tem que consertá / (( voz mudada)) rápido...rápido... vamos consertá /

130-JP: ((pára e olha))

131-A: no::ssa destruiu toda a má::quina (( mostra os blocos desmontados))

132-JP: então e \{agora?

133-A: $\quad$ agora?

134-JP: (( coloca os blocos atrás dele)) ele vai construir um máquina mas ela tá escondida aqui no monte tá bom:?

135-A: a Emília tá escondida aqui? ((olha o monte))

136-JP: (( continua montando)) não ...mas ele vai (atacar ela) 
138-A: não... mas ela vai esconder em outro lugar.... mas ela vai se esconder mais longe... longe (( pega a Emília e esconde em outro lugar))

139-JP: olha a espaçonave ((mostra a peça)) vvvum vvvum ((onomatopéia, risada))

140-A: vou esconder a Emília ....((voz natural)) soCOrro soCOrro ....foge vou esconder aqui ((com mudança da voz , movimenta a Emília em fuga))

141-JP: (( persegue a Emília com a espaçonave)) vvvmmm vvvvmmm (( onomatopéia ))

142-A: tenho que consertá/ minha máquina ... vou ter que usar o pó de pirlimpimpim ...vou sumir daqui ((com mudança da voz $))$ aí ela sumiu agora ((voz natural)) ((esconde a Emília))

143-JP: óh o Visconde

144-A: o Visconde ficou pensando para onde foi a Emília ((voz natural))... onde foi a Emília ((com mudança da voz ))

145-JP: a espaçonave agora tztztz agora é uma....super arma... lança um monte ... monte ... de.:.. água que pode assim óh ... (( joga-se no chão)) e morre afogada

146-A: mas ela usô/ o pó de pirlimpimpim e ela sumiu

147-JP: mas ele tá com outro poder... voa alto ((levanta e faz movimento de vôo com a peça)) tzz vzvzz (( onomatopéia ))

148-A: e como faz para encontrá / a Emília....agora se ela usou o pó de pirlimpimpim?

149-JP: olha agora tz ((onomatopéia, joga-se no chão e olha A))

150-A: no::ssa:::: está cheio de água aí? (( aponta para o lugar onde ele está))

151-JP: não ... ele vai sentí / ..... onde está a Emília assim ... por debaixo da terra (( olha A))

152-A: ah:: ele vai sentir onde está a Emília? ... por debaixo da terra?

153-JP: vai sim... asSIM... quando faz assim ele acha (( começa a engatinhar e rastejar a peça ))

154-A: encontrô / ?

156-JP mas acho que agora tem que tirá / a Emília

157-A: tirá / daonde?

158-JP: daonde ela tiVÈR

159-A: mas se tira então eles vão achá/

160-JP: mas..mas...daí... aí ela pode corrê / até o Visconde e atirál lá onde está o Visconde (( aponta onde o Visconde está))

161-A: ah é ... então eu vou fazer isso.... vamos lá (( pega a Emília e coloca rápido junto do Visconde))

162-JP (( ele segue rápido atrás)) tztz tztz ((risadas))

163-A: vai lá .... ataquei... atirei no Visconde ....(( combate entre as peças de A e JP )) a máquina do Visconde caiu (( desmonta a máquina do Visconde, risadas))

164-JP: (( risadas $))$ atirei... \{tztz ...(( onomatopéia de tiro $))$ atirei

165-A: $\quad\{$ vamos lá...vamos la'...vô/ consertá / minha máquina ((com mudança da voz ))

166-JP: vamos consertá / a máquina dele ((com mudança da voz, faz encaixes))

167-A:((faz encaixes)) vou consertá/a máquina a minha também ((com mudança da voz))

168-JP: olha a máquina dele (( mostra a peça))

169-A: ((olha para JP )) já ficô/ consertada?

170-JP: JÁ 
171-A: nossa que rápida essa máquina hein? (( monta rápido as peças dela))

172-JP: tz.. ((onomatopéia de tiro)) atacar agora ...vai atacar a sua ((ataca a peça de A))

173-A: nã:::o::.:.... óh::.:......((rola a máquina no chão))

174--JP: pega ela ((com mudança da voz ))

175-A: ((pega a Emília)) vamos fugir... vou esconder atrás da minha máquina ((com mudança da voz))

176-JP: não pode vir para abaixo tá? ((voz natural))

177-A: como assim? (( olha JP))

178-JP: só pode assim ..olha ..assim no teto (( mostra o vôo da espaçonave que não pode virar de cabeça para baixo))

179-A: ah...tá bom (( olha JP))

180-JP: vô/ pega essa espaçonave e aqui tz $t z$ tz...((onomatopéia de tiro, com mudança da voz ))

181-A: ah ela tá escondida.... (( coloca muitas peças sobre a Emília encobrindo-a)) e não dá para vê/ a Emília 182-JP: (( pega a espaçonave e voa como procurando a Emília))

183-A: ela tá escondida... você não pode olhá / ela ... ela tá escondida

184-JP: esconde aqui.... esconde aqui (( aponta outro esconderijo , uma sacola plástica))

185-A: não ela tá lá escondida... olha lá ninguém tá vendo ela lá

186-JP: esconde aqui...esconde aqui embaixo desse plástico aqui

187-A: não...mas ninguém tá vendo ela ((aponta o esconderijo))

188-JP: (( pega a sacola plástica e põe na frente da espaçonave)) agora...assim ele viu...ele viu...um... cabelo $(($ olha A))

189-A: ((sorri)) ele viu um caBElo?

190-JP: viu (( larga a sacola))

191-A: como ele viu um cabelo.. não tô / vendo cabelo nenhum

192-JP: ((conduz a nave ao esconderijo)) cuidado tztz bummm (( desmonta o esconderijo, espalhando as peças))

193-A: gente ... como ele consegui ver?

194-JP: assim óh... tinha um pouquinho assim óh... (( mostra, na sua cabeça, um pedaço do seu cabelo)) um pouquinho pra fora

195-A: mas é um pedaço muito \{pequenininho

196-JP: $\quad$ \{pega ela ..... bunzzzz explodiu.... \{explodiu tudo

197-A: $\quad$ \{explodiu tudo explodiu tudo....então tem que desmontá/ porque se explode tem que explodí/ tudo (( desmonta todas as peças encaixadas, separando os blocos))

198-JP: e o Visconde fica assim óh...vendo

199-A: pensando de novo

200-JP: óh agora....(( tira um bloco da sua máquina do Visconde )) pzzzz (( levanta e deixa cair sobre as outras espalhando todos os blocos)) se acha que a arma não é mais forte?

201-A: (( observa)) é acho que é a arma mais forte

\section{Episódios: criança N}




\section{Episódio carro}

1-A : você está tendo uma iDÉia?

2-N : ((silêncio, monta alguma coisa e mostra o que montou, olha para A )) é um carrinho

3-A: Um carrinho para Ele

4-N: \{e outro para ela

5-A: \{ e outro para ela

6-A: o carro dela é diferente do dele

8-N: eh

9-A: mas tem ROda

10-N: é

\section{Episódio casa do sítio}

15-A: isto...aonde eles estão INdo?

16-N: no sítio do pica pau amarelo

17-A: no SÍtio eles vão?

18-N: ((silêncio))

19-A: vamos fazer uma casa do SÍtio?

20-N: eu não sei fazer uma casa

21-A: imaGIna ...não sabe fazer uma CAsa

22-N: tem uma teLHAdo ...uma PORta

23-A: exatamente ...tem a porta (( encaixa alguns blocos e tenta montá-los))

24-N: e é bem:... GRANde ...o que você está faZENdo?

25-A: o quê?

26-N: uma CAsa?

27-A: uma casa...perai/ ...tem que ficar bem grande

28-N: perai/...tinha que ter uma porTInha ((encaixa uns blocos))

29-A: seRÁ que eles passam aqui Já?....((tenta passar o carro pela passagem entre os "legos" montados)) ah! mas eles não vão passar com o CArro né ? ...eles vão passar Sem o carro

30-N: não... eles vão passar COM o carro

31-A: com o CArro? DENTro da CAsa?

32-N: eh

33-A: ou essa é a porta do SÍtio?

34-N: ((silêncio continua encaixando os blocos do jogo, termina, olha A))

35-A: ah... enTÃO tem que ser mais comPRIdo não tem?

36-N: não ((silêncio tira uma peça do lego para a passagem não ficar difícil))

37-A: e o teLHAdo... não vai ter teLHAdo?...vamos ver .......esse aqui pode ser o telhado (( escolhe entre os blocos uma peca para ser encaixada.))

38-N: shi ...é o telhAdo ((olha para A com cara de dúvida))

39-A: mas eles não conseguem passar...vou por o telhado aSSIM... seRÁ que eles PAssam? vamos ver 
40-N: de carro...não devem passar ...\{ \{a pé ((faz tentativa com o carro montado de passar por debaixo da casa montada))

41-A: $\quad$ a pé deve ...de carro não ? ...... passou ou não passou?

42-N: não...não porque eles estão muito ALto

43-A: então tem que fazer esse ficar MAIS alto ((aponta as pecas encaixadas que deviam ser modificadas))

44-N: a gente põe esses aqui ((pega outros blocos e aponta onde pretende encaixá-los))

45-A: este (( mostra outro bloco $))$

46-N: este

47-A: este ... será que agora dá?

48-N: dá (( tenta encaixar uma peça e não consegue))

49-A: põe aSSIM ...VAmos ver ((observa))

50-N: ((faz o movimento do carrinho passando por baixo do bloco encaixado)) DA

51-A: DEu?

52-N: só não passa o chapeuZInho um pouquinho

53-A: ah... passa BEm raspando

\section{Episódio passeio de carro}

67-N: não ...mas agora eles SÓ vão andar de CArro

68-A: andar por onde ...por AI?

69-N: é por AÍ ...para a pedra MÁgica... a pedra mágica é que uma pessoa é BRUxa ...tem uma filhinha ...é boaZInha... que ela tem um neGÓcio lá ... aí a Narizinho vira pedra

70-A: porque?

71-N: porque ela não gosta DEla ...do NariZInho

72-A: a bruxa não gosta do NariZInho?

73-N: ((silêncio))

74-A: nem dos outros persoNAgens?

75-N: NEm...nem do Visconde ...da Emília

76-A: e porque só a Narizinho virou PEdra?

77-N: porque ela tava passeANdo ...passeANdo e não sabia... eh (( fez um gesto como se mostrasse que estava dura ))

78-A: entendi

79-N: a Narizinho é uma pedra (( movimenta o carro do Visconde e da Emilia como se estivessem procurando a Narizinho))

80-A: eles estão procurando a Narizinho? ... e uma pedra?

81-N: aqui é ela ((pega um bloco, mostra e coloca num certo lugar no espaço da brincadeira ))

82-A: certo ...e eles enCON $\{$ tram?

83-N:

\{enCONtra

84-A: e depois ela consegue virar GENte?

85-N: ahn ahn...... não sei eu não assisti esse peDAço

86-A: ((sorri)) 


\section{Episódio carro}

103-A: $\quad$ e.......esse outro que está com você?

104-N: é um carro

105-A: é um carro...e quem está no carro?

106-N: a Emília e o Visconde

107-A: ih.... é mesmo a Emília e o Visconde ....e você fez o cortador de grama

108- N: (( empurra o carro com o cortador de grama))

109-A: mas o cortador de grama está empurrando o carro?

110-N: ((sinal de sim com a cabeça $))$

111-A: como pode isso?

112-N: poDENdo ((empurra mostrando, olha para A))

113-A: podendo COmo? .... ah... assim:::

114-N: (( brinca com o carro e o cortador que desmonta várias vezes)) ih.. de novo

115-A: esse cortador está toda hora CAINdo... porque seRÁ ?

116-N: precisa apertar (( pega os blocos e tenta encaixar com força))

117-A: conseguiu apertar?

118-N: ((sim com a cabeça, brinca com o cortador de grama))

\section{Episódio rato}

119-A: ((observa))

120-N: aÍ.....só falta uma coisa espera um pouco ((pega o cortador e encaixa mais uma vez com mais firmeza fazendo expressão de esforço))

121-A: ahn? que qui tá faltando?

122-N: Isso

123-A: que qui é isso?

124-N: um RAto

125-A: que qui é ISso...rato tem roda?

126-N: não ...isso é a PERna dele NÉ

127-A: mas ele

128-N: senão ele não $A N d a$

129-A: certo... mas o rato tem rabo....cadê o rabo?

130-N: não dá para fazer

131-A: ah ...então ele vai ficar sem rabo?

132-N: uh...rabo dele tinha cortado...tava quase mortinho

133-A: coitado... ah....... ah... ((fazendo expressão de dó))

134-N: como que faz:... ... ((coloca uma peça e mostra para A)) a cabeça dele

135-A: ah:...agora ele tem cabeça...ele tava sem cabeça antes?

136-N: como que pode fazer o rabo? ...ah.já sei 
137-A: você vai inventar um rabo?

138-N: (( encaixa uma peça)) esse é o rabo ((sorri e olha para A))

139-A: você pôs o rabo nele.. agora o rabo cresceu?

140-N: não

141-A: você disse que tinha cortado

142-N: é verdade...

\section{Episódio Cuca}

143-A: o dia que eu assisti o sítio o nome da bruxa era Cuca

144-N: eu sei ...essa não é ...é outra ((sem olhar para A))

145-A:ué::.. não é a Cuca? (( começa a fazer montagens))

146- N: não

147-A: a Cuca é outra?

148-N: ((Responde sim com a cabeça sem olhar para A))

149-A: CUca parece um jacaré

150-N: parece e é um jacaré

151-A: é um jacaré a Cuca né?...óh..... eu fiz um jacaré ...fiz a Cuca.

152-N: legal (( olha a Cuca))

153-A: parece uma Cuca não é?

154-N: ((olha e sorri)) legal

155-A: agora a Cuca vai atrás deles...vai jogar um pó mágico neles ela vai colocar o pó mágico aqui 156-N: ela não tem pó mágico

157-A: quem tem pó mágico?

158-N: é a outra bruxa...e ela tem um caldeirão... e ela gosta de jogar no caldeirão

159-A:uhn... uhn ..então deixa eu ver um caldeirão (( pega uma peça montada e coloca como caldeirão))

160-N: essa é a caverna dela

161-A: de quem?

162-N: dela (( aponta para a Cuca))

163-A: da Cuca? ela entrou na caverna dela e está mexendo no caldeirão dela?

164-N: ((silêncio))

165-A: e se a Cuca jogar um feitiço neles?

166-N:aí eles tem que se livrál

167-A: eles conseguem se livrar?

168-N: consegue

169-A: como?

170-N: conseguindo 
ANEXO - III

Foto A) Jogo LEGO

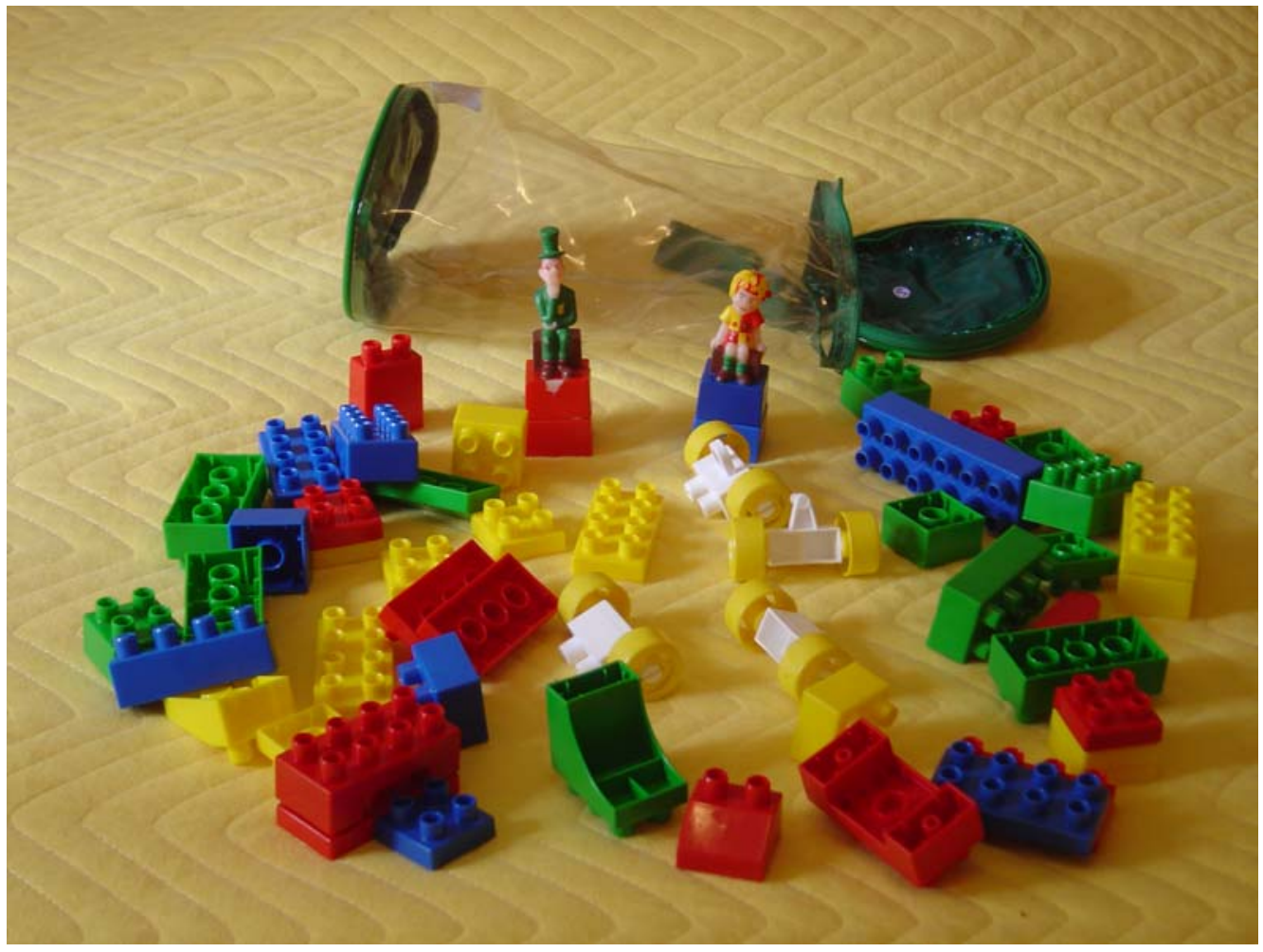

Foto B) adulto e criança com o jogo LEGO

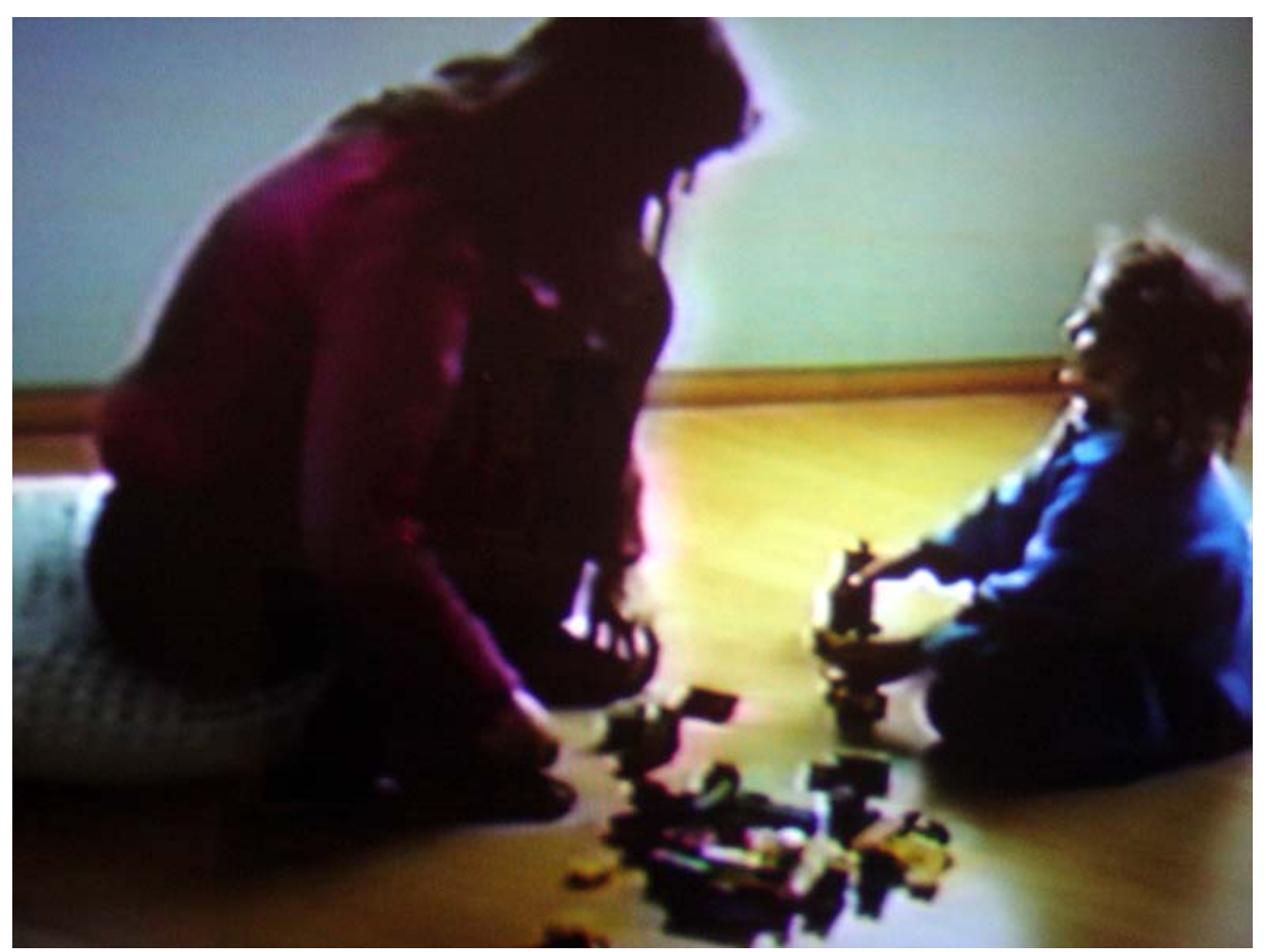


